\title{
Dengue e infestação do Aedes aegypti no município de Santo André, São Paulo
}

\author{
José Luís Laporta
}

Tese apresentada ao programa de PósGraduação em Saúde Pública da Faculdade de Saúde Pública da Universidade de São Paulo para obtenção do título de Doutor em Saúde Pública.

Área de Concentração: Epidemiologia Orientador: Prof.Dr. José Maria Soares Barata

\section{São Paulo 2004}


Aos meus pais, Angelo (in memorian) e

Maria da Glória, pelo esforço dedicado à educação de seus filhos.

Aos meus irmãos, pelo amor que nos une. 
À minha esposa Márcia, pelo seu companheirismo, amizade e amor, fundamentais à realização desse trabalho.

Aos meus filhos Juliana e Gabriel, a quem eu dedico esse trabalho, pelo amor e pelo carinho recebidos. 


\section{O Mosquito}

$p_{\text {arece mentira }}$

De tão esquisito:

Mas sobre o papel

feio mosquito

fez sombra de lira!

(Dinicius de Moraes, 1959) 


\section{AGRADECIMENTOS}

Ao Prof. Dr. José Maria Soares Barata, orientador desse trabalho, pelo apoio, estímulo, compreensão nos momentos mais críticos e pela grande amizade demonstrada.

Ao Prof. Murilo Andrade Valle, pela ajuda na digitalização e confecção dos mapas utilizados nesse trabalho.

Ao Prof. Alcides Eduardo Jacomassi, pelos gráficos e cálculos estatísticos aplicados na tese.

À Dra. Rosa Maria de Aguiar, por disponibilizar as informações sobre dengue, do Departamento de Vigilância à Saúde de Santo André.

Ao Prof. Dr. Delsio Natal, pelo incentivo, sugestões e amizade.

À Rosa Maria Fontes, pela inestimável ajuda na formatação dos textos e impressão da tese.

À Januária Cristina Dani, pela ajuda na digitação das planilhas.

À Patrícia Pucci, pela ajuda na digitação dos textos.

À Profa. Svetlana Ponomarenko Lazaro, pela tradução do resumo para a lingua inglesa.

Ao Prof. Úmile Calasso Sobrinho, pela revisão dos textos e pelas sugestões. 
À Profa. Dra. Carmem Beatriz T. L. da Costa, pelas sugestões, incentivo e amizade.

Aos técnicos e funcionários do Departamento de Vigilância à Saúde de Santo André, Sonia Oliveira Barbosa, Robson Oliveira Lopes e Maria de Lourdes Ladislau Martins pela presteza e fidedignidade dos dados utilizados nesse trabalho.

Aos técnicos do Laboratório de Culicidologia, Paulo Roberto Urbinati, Walter Ceretti Junior e Marcos Obara, pelo incentivo e amizade.

Ao gerente do Setor de Controle de Zoonoses do Departamento de Vigilância à Saúde de Santo André, Rodolfo Andreani Sobrinho pelo fornecimento dos dados de infestação e pelo apoio.

Aos funcionários da Secretaria de Planejamento da Prefeitura de Santo André, pelo fornecimento de dados do município.

À Profa.Dra. Nilza Nunes da Silva, pelas sugestões com relação à parte estatística.

À Eudina de Freitas Barata, pelo incentivo e amizade.

Aos professores e funcionários do Departamento de Epidemiologia da Faculdade de Saúde Pública da USP, pelo apoio recebido. 


\section{RESUMO}

Laporta JL. Dengue e infestação do Aedes aegypti no município de Santo André, São Paulo.[Tese de Doutorado - Faculdade de Saúde Pública Universidade de São Paulo].

Objetivos. Descrever o perfil epidemiológico da dengue no municipio de Santo André e discutir os coeficientes de incidência e índices de infestação do Aedes aegypti. Método. A área de estudo foi o município de Santo André, São Paulo, no período de 1998 a 2002 para os casos de dengue e de 1998 a julho de 2003 para a infestação do Aedes aegypti. Os dados obtidos foram utilizados para cálculo do coeficiente de incidência e índice de infestação mensais e anuais e para descrever a distribuição espacial e temporal. Os registros de temperatura, umidade e precipitação foram utilizados para teste de correlação com a infestação do vetor. Resultados. A incidência mostrouse maior em individuos com idade superior aos 50 anos, não tendo sido verificada diferença na incidência relativa ao sexo. Os casos registrados são importados, sendo a maior parte proveniente da cidade de Praia Grande (52\%). A infestação teve seu início na região fronteiriça do municipio, limite com a cidade de São Paulo. Com relação à incidência de dengue, verificouse que em todas as áreas nas quais o município está dividido, houve registro de casos importados. A incidência e a infestação foram maiores nos primeiros meses do ano. Foi positiva a correlação entre infestação e temperatura média; a correlação entre pluviosidade e infestação foi baixa e não houve correlação entre a umidade relativa e a infestação do Aedes aegypti. O criadouro com maior freqüência no municipio foi o vaso. Conclusões. Idade superior aos 50 anos e viagens de lazer ao litoral representaram os maiores riscos nos casos importados de dengue. Em toda a área urbana do município ocorreram casos de dengue e infestação do mosquito. A incidência da doença e a infestação do vetor revelaram uma distribuição sazonal. Os fatores antrópicos revelaram-se importantes na infestação do Aedes aegypti no município.

Descritores: Dengue, Epidemiologia, Aedes aegypti, criadouros 


\section{SUMMARY}

Laporta JL. Dengue and the infestation of the Aedes aegypti in Santo André county, São Paulo. [PhD thesis-School of Public Health - Universidade de São Paulo].

Aim. To describe the epidemiological profile of dengue in Santo Andre county and the infestation of the Aedes aegypti. Method. The studied region was Santo Andre county, São Paulo from 1998 to 2002 for the dengue cases and from 1998 to july/2003 for the infestation of the Aedes aegypti. The obtained data were used to calculate the incidence coefficient and monthly and annual infestation rate as well as to describe the space and time distribution. The temperature humidity and precipitation registers were used for the correlation test with the vector infestation. Results. The incidence proved to be higher in individuals aged over fifty but difference in the incidence related to the male or female sex was not verified. The recorded cases are imported, most of which are originated from Praia Grande city (52\%), São Paulo state. The infestation had its beginning on the border line region of the county, bordering on São Paulo city, a place characterized by the distinguishing presence of scrap iron business. As to the dengue incidence, it was noticed that in all the regions into which the county is divided, a record of imported cases was made. The incidence and the infestation were greater at the beginning of the year. The correlation between the infestation and the average temperature was positive; the correlation between the rainfall an the infestation was low and there was no correlation between the relative humidity and the Aedes aegypti infestation. The most frequent breeding place in the county was the vase. Conclusions. The incidence of the imported cases of dengue is greater among the adult population and the disease is acquired during the leisure trips. In all the urban region of the county, cases of dengue and mosquito infestation occurred. The incidence of the disease and the vector infestation revealed a seasonal distribution. The anthropic factors proved to be important to the Aedes aegypti infestation in the county.

Descriptors: Dengue, Epidemiology, Aedes aegypti, breeding sites. 


\section{ÍNDICE}

Introdução 1

$\begin{array}{ll}\text { Objetivos } & 14\end{array}$

Material e Métodos $\quad 15$

Área de estudo 15

Infestação do Aedes aegypti 21

Fatores ecológicos $\quad 21$

Casos de dengue $\quad 22$

Dados demográficos $\quad 23$

Distribuição espacial da dengue e da infestação 24

Resultados e Discussão $\quad 25$

Incidência de Dengue em Santo André 25

Incidência de dengue em relação ao mês do ano $\quad 30$

Origem dos casos importados $\quad 32$

Incidência em relação à idade $\quad 37$

Incidência relativa ao sexo $\quad 40$

Distribuição de dengue segundo o grau de instrução 42

Distribuição espacial e temporal dos casos importados 45

Infestação do Aedes aegypti e fatores ecológicos $\quad 57$

Distribuição espacial do Aedes aegypti 62

$\begin{array}{ll}\text { Tipos de criadouros } & 72\end{array}$

Positividade e distribuição de larvas por criadouro 81

Recomendações $\quad 89$

Conclusões $\quad 91$

Referências $\quad 93$

$\begin{array}{ll}\text { Anexos } & 106\end{array}$ 


\section{1 - INTRODUÇÃO}

A reemergência das infecções pelo vírus da dengue nas Américas, sob a forma de epidemias de dengue clássico, febre hemorrágica e síndrome do choque de dengue, coloca essa arbovirose como um dos mais graves problemas de saúde pública do continente. Essa enfermidade, de acordo com ALBUQUERQUE e col., 2000, é originária da Ásia, onde, ainda hoje, ocorre em ambiente rural e transmitida pelo Aedes albopictus. Em ambientes urbanos o vetor da dengue é o Aedes aegypti.

Esse mosquito, originário do continente africano, habitava primitivamente as matas da região da Etiópia, utilizando como criadouros, em seu centro endêmico natural, ocos de árvores e outras cavidades do meio (CROVELLO e HACKER 1972). Daí, expandiu-se para outros continentes e, segundo SMITH,1956, na segunda metade do século XIX, quando de sua introdução no continente asiático, a espécie já se encontrava domiciliada. Atualmente, sua distribuição ocorre entre as latitudes de $45^{\circ} \mathrm{Ne}$ $40^{\circ} \mathrm{S}$, abrangendo as regiões tropicais e subtropicais (SLOSEK 1986, FORATTINI 2002).

Esse mosquito destaca-se por sua antropofilia e sinantropia, procriando em diversos recipientes artificiais como pneus, caçambas, vasos e latas, entre outros (CENTERS FOR DISEASE CONTROL 1979). Para FORATTINI,1992, o fenômeno da domiciliação ou sinantropia é uma condição representada pela adaptação de espécies ao convivio humano, 
resultando na ocupação de nichos artificialmente criados no ambiente antrópico. A destruição dos habitats naturais pode ter selecionado uma variedade genética do Aedes aegypti que adaptou-se em áreas alteradas e ecossistemas urbanos, encontrando, nesses locais, o ambiente adequado para sua sobrevivência (CHRISTOPHERS 1960). A grande tendência à endofilia revelada por esse mosquito, em área de transmissão de dengue, é um fator a ser levado em consideração na epidemiologia da doença (BARATA e col. 2001).

A adaptação aos criadouros artificiais foi um grande passo em direção ao comportamento sinantrópico, sendo esse mosquito, hoje, altamente dependente dos recipientes manufaturados pelo homem. Esses recipientes que armazenam água, além de servirem de criadouros para o desenvolvimento do mosquito, podem, ao serem transportados pelo homem para outras áreas, ajudar a dispersão do Aedes aegypti, já que os ovos depositados pela fêmea nas paredes desses recipientes possuem grande resistência. Dessa forma, essa espécie foi conquistando territórios, ao utilizar o transporte passivo como um dos meios de dispersão. Uma espécie, com essa capacidade de adaptação ao ambiente urbano, representa risco, se estiver envolvida com a transmissão de alguma doença. Esse é o caso do Aedes aegypti.

Desde o histórico trabalho de Finlay, realizado em Cuba em 1881, o Aedes aegypti vem sendo incriminado como transmissor da febre amarela urbana e, posteriormente, como vetor da dengue, como demonstrado por Bancroft, em 1906 (DONALISIO 1999). 
A febre amarela é doença causada por virus pertencente à família dos Flaviviridae (Arbovirus B), composta por cerca de setenta espécies de vírus que, em sua maioria, são transmitidos aos vertebrados por mosquitos ou carrapatos (BENCHIMOL 2001 ). A forma urbana dessa doença é transmitida pelo Aedes aegypti, enquanto que a forma silvestre é transmitida por mosquitos do gênero Haemagogus e outros. A doença é causada pela replicação viral em órgãos como baço, rim e principalmente figado, onde causa lesões. Não existe tratamento específico para a febre amarela, embora exista um eficiente meio profilático que é a vacina. A vigilância epidemiológica é da maior importância no controle dessa doença (TRABULSI 1989).

Nas Américas, atualmente, a febre amarela é enzoótica. O homem participa do ciclo da doença de maneira acidental, originando os casos de febre amarela silvestre. Embora essa doença tenha sido assinalada desde o século XVII no Brasil, é a partir da metade do século XIX que os casos urbanos de febre amarela alcançaram índices elevados, em várias cidades brasileiras. O último registro dessa doença data de 1942, na cidade de Sena Madureira, no Acre (BENCHIMOL 2001). Todavia, em virtude da persistência do vírus em áreas enzoóticas, aliada à presença do vetor nas cidades, atualmente apresenta-se a ameaça de reintrodução da forma urbana da febre amarela (FORATTINI 2002).

No Brasil, os primeiros registros de febre amarela ocorreram no século XVII em Pernambuco e Bahia. No século XIX, essa doença, na sua forma urbana, era encontrada em várias cidades dos estados do Pará, 
Maranhão, Rio Grande do Norte, Paraiba, Pernambuco, Alagoas, Bahia e Rio de Janeiro (FRANCO 1976).

Em São Paulo, as cidades de Santos e Sorocaba, em 1901, e outros municipios como Itu, Campinas, Mogi das Cruzes, Ribeirão Preto e alguns do Vale do Paraíba, em 1903, apresentavam-se com epidemia de febre amarela (SUCEN 1993). Foi Emilio Ribas quem propôs, inicialmente em Sorocaba, em 1901, o combate ao mosquito Aedes aegypti, acreditando na teoria de Finlay como medida saneadora da febre amarela urbana (FRANCO 1976). Posteriormente, em 1903, em São Simão e em Ribeirão Preto, Emilio Ribas, utilizando intensa campanha contra o mosquito, conseguiu o controle da epidemia nessas cidades (FRANCO 1976).

Em 1904, Oswaldo Cruz incluiu o combate ao mosquito em sua campanha contra a febre amarela no Rio de Janeiro (FRANCO 1976; SUCEN 1993).

A partir da década de 20, o Brasil desenvolve intenso combate ao Aedes aegypti, como forma de se evitar a ocorrência de novas epidemias de febre amarela urbana, por meio de um convênio firmado entre o governo brasileiro e a Fundação Rockefeller (FIGUEIREDO 1998).

O Aedes aegypti foi declarado erradicado do Brasil em 2 de outubro de 1958, na XV Conferência Sanitária Panamericana, realizada em Porto Rico. Naquela época, o último foco desse mosquito foi encontrado na cidade de Santa Terezinha, Bahia, em abril de 1955 (SEVERO 1959; SOPER 1963; FRANCO 1976). 
No entanto, em 1967, foi detectada a presença do Aedes aegypti em Belém, Pará. Já em 1968, esse mosquito estava presente em São Luiz e São José do Ribamar, Maranhão. Em 1976 e 1977, a dispersão do mosquito atingiu a cidade de Salvador, Bahia, e a cidade do Rio de Janeiro (OPAS 1991; S.E.S. 1997).

A dispersão do Aedes aegypti, trouxe a preocupação de ocorrência de novas epidemias de febre amarela urbana e de dengue, já que essa doença, a partir da década de 60 e, principalmente, na década de 70 encontrava-se na América Central e México. A partir da década de 80 , tem início, de forma epidêmica, a ocorrência de dengue em países da América do Sul (FABBRO 1997).

A dengue é uma doença aguda causada por quatro sorotipos virais, denominados DEN 1, DEN 2, DEN 3 e DEN 4, pertencentes ao gênero Flavivirus, e que se manifesta clinicamente com gravidade variada. São conhecidas as formas de Dengue Clássica, Febre Hemorrágica da Dengue e Síndrome do Choque da Dengue (DONALISIO 1999).

Os sintomas da dengue clássica são cefaléia, febre, artralgias, mialgias e prostração. Esses sintomas, em grau variado, podem se manifestar em síndrome viral inespecifica até a extremamente severa forma hemorrágica. A forma clínica, denominada Febre Hemorrágica da Dengue (FHD) e a Síndrome do Choque da Dengue (SCD), manifesta-se com um quadro febril agudo, taquicardia, hipotensão, diminuição da perfusão dos tecidos periféricos e manifestações hemorrágicas. Essa manifestação envolve vários fatores, como a idade do paciente, estado imunológico e a 
predisposição genética da pessoa infectada. A infecção por um dos vírus não significa desenvolvimento de imunidade para os demais (FORATTINI 2002).

Naquela época, a preocupação com uma possivel ocorrência de casos de dengue no Brasil era justificada, pois, em 1982, foi registrada uma epidemia de dengue na cidade de Boa Vista, Roraima, com a circulação dos sorotipos DEN-1 e DEN-4 (OSANAI 1983). Em 1986 e 1987, a doença ocorreu de forma epidêmica no Rio de Janeiro, com a confirmação de 93.910 casos do sorotipo DEN-1. A partir desse momento, observou-se um aumento do número de estados brasileiros com casos de dengue (FUNASA -CVE 2003).

No estado de São Paulo, os primeiros registros da reintrodução do Aedes aegypti datam de fevereiro de 1980, na cidade de Santos. Em 1981, foram detectados 5 focos naquela cidade. No entanto, a dispersão desse mosquito no estado de São Paulo ocorreu a partir dos municípios localizados na região oeste e que fazem fronteira com cidades do estado de Mato Grosso do Sul. Daí, a dispersão do mosquito ocorreu no sentido leste do estado (GLASSER 1997; GLASSER E GOMES 2002).

Em 1985, em levantamento realizado pela SUCEN no estado, foi detectada a presença do vetor em 12 municípios, tendo sido confirmada a infestação domiciliar em 8 desses municípios, todos na região oeste do estado. Desde então, a infestação pelo Aedes aegypti vem se expandindo (DONALISIO 1998). 
A dispersão do mosquito trouxe a possibilidade de ocorrência de casos de febre amarela urbana, pois a forma silvestre, desde o primeiro relato de sua ocorrência feito por Adolfo Lutz, em 1929, continua a ocorrer no território brasileiro. No ano de 2003, foram registrados 62 casos de febre amarela silvestre nos estados do Acre, Minas Gerais e Mato Grosso (FUNASA/CENEPI/CGVEP/COPEV -2003). Embora o Aedes aegypti não esteja envolvido com a transmissão da forma silvestre da doença, existe o risco de epidemias da forma urbana ocorrerem se não for realizado um controle adequado em cidades infestadas por esse vetor.

Nesse sentido, MASSAD, 2003, estudando a possibilidade de ocorrência de febre amarela urbana, em uma área com transmissão de dengue, demonstrou que existe um grande contingente de pessoas não vacinadas contra febre amarela vivendo em áreas infestadas pelo Aedes aegypti no estado de São Paulo e estimou o número total de pessoas que vivem em áreas de alto risco para a febre amarela urbana. Por sua vez, PENNA, 2003, diante do perigo do reaparecimento da febre amarela urbana, ressalta a necessidade da atuação conjunta da área de saneamento e meioambiente, devendo ser repensada a contribuição da população no estabelecimento de uma nova estratégia para lidar com esse problema.

A presença do Aedes aegypti nos ambientes urbanos envolve outro aspecto importante, ou seja, a possibilidade de ocorrência de epidemias de dengue, principalmente, em cidades com elevada densidade populacional, como é o caso de várias cidades do estado de São Paulo e da região metropolitana de sua capital. 
O primeiro relato sobre epidemia de dengue no estado de São Paulo ocorreu em 1987, nos municípios de Guararapes, com 30 casos, e Araçatuba, com 16 casos confirmados do sorotipo DEN-1 (SES 1987). Em 1990 e 1991, uma grande epidemia ocorreu na região de Ribeirão Preto, São Paulo, com a notificação de 6.800 casos confirmados. Após uma diminuição da transmissão, em 1992, possivelmente devido às ações de combate ao vetor, realizadas por esses municípios, registraram-se 638 casos, em 1993, e 681 casos, em 1994, atingindo cidades consideradas sedes administrativas como São José do Rio Preto, Ribeirão Preto, Catanduva, Barretos e Araçatuba. A partir de 1995, têm ocorrido epidemias todos os anos de dengue clássico e, a partir de 1999, há registro de casos hemorrágicos. Houve uma diminuição da incidência, em 1997 e 2000. No ano de 2003 , dados de até 20 de dezembro, o número de casos foi menor que o ano anterior, embora esse número ainda permaneça alto (Tab. 1). 
Tabela 1 - Distribuição de casos confirmados e incidência de dengue, segundo o ano, no estado de São Paulo, 1995 a 2003.

\begin{tabular}{lcc}
\hline ANO & NÚMERO DE CASOS & INCIDÉNCIA/100.000 HAB. \\
\hline 1995 & 6.048 & 18,02 \\
1996 & 7.104 & 20,85 \\
1997 & 2.040 & 5,89 \\
1998 & 10.630 & 30,2 \\
1999 & 15.082 & 42,3 \\
2000 & 3.520 & 9,4 \\
2001 & 51.472 & 142,3 \\
2002 & 41.948 & 109,8 \\
$2003^{*}$ & 20.292 & 53,12 \\
\hline Fonte: Divisão de Zoonoses - CVE - São Paulo \\
* Dados até 20/12/2003
\end{tabular}

Em relação ao território brasileiro, no ano de 2003, em 24 estados, ocorreu circulação dos sorotipos 1, 2 e 3. Em dois estados somente, Santa Catarina e Rio Grande do Sul, não há confirmação de casos autóctones (FUNASA/CENEPI/CGVEP/COPEV -2003).

$\mathrm{Na}$ ausência de uma vacina, quimioprofilaxia ou mesmo tratamento, a forma encontrada para reduzir a transmissão da dengue restringe-se ao controle do Aedes aegypti. Esse mosquito encontra-se extremamente adaptado ao convívio com o homem. Trata-se de espécie que possui populações altamente sinantrópicas que infestam cidades e transmitem doenças como a dengue e a febre amarela. No mundo moderno, o homem, 
devido ao seu comportamento, facilita recursos a esse mosquito e auxilia sua dispersão.

Assim, as mudanças demográficas ocorridas em diversas cidades, geradas por intenso fluxo migratório rural-urbano, resultaram em crescimento desordenado, favorecendo a disseminação do vetor da dengue e o ressurgimento dessa doença (TAUIL 2001).

A Organização Panamericana da Saúde (OPAS), em 1995, salienta a importância da vigilância entomológica para determinar as mudanças na distribuição geográfica do vetor, a distribuição da população vetora ao longo do tempo, a distribuição espacial e a identificação de áreas de alta densidade populacional do vetor. Essas informações são essenciais para detectar novas introduções e a tomada de decisões corretas e oportunas, relativas a intervenções.

A grande heterogeneidade ambiental dos centros urbanos, onde o vetor da dengue prolifera, aliada à escassez de recursos e de pessoal treinado para o controle de mosquitos, dentre outros fatores, constitui dificuldade para o controle da doença. Uma adequada vigilância epidemiológica pode servir de base para estratificar os centros urbanos e identificar as zonas criticas, nas quais devem se concentrar as tarefas de prevenção e controle (BARRERA 2000).

O estilo de vida humano é, atualmente, a chave da ecologia moderna. Nos últimos 200 anos, as cidades cresceram e se multiplicaram rapidamente pelo mundo inteiro. As cidades são fonte de criatividade, tecnologia e crescimento econômico. Entretanto, são, também, fonte de pobreza, 
desigualdade e riscos para a saúde do ambiente. As populações urbanas têm sido, há algum tempo, incubadoras e portas de saídas de doenças infecciosas (McMICHAEL 2000).

Fatores associados ao modo de organização das populações humanas têm papel importante no estabelecimento de criadouros de Aedes aegypti, junto aos núcleos populacionais urbanos (CHIEFFI 1985). FORATTINI, 1992, destacou que investigações sobre o comportamento humano, associadas aos aspectos estruturais e funcionais da sociedade, fornecem informações indispensáveis sobre o papel epidemiológico que determinadas populações de mosquitos podem assumir em diferentes regiōes.

De acordo com DONALISIO, 1999, a organização da sociedade, a estrutura urbana, as políticas de investimento no controle e a vigilância são determinantes para a ocorrência da dengue. As epidemias de dengue comprovam a circulação do vírus e a presença do contato homem-mosquito. Além disso, dependem, também, de fatores tais como nível sócio-econômico da população, indicadores de qualidade ambiental, níveis de infestação do vetor, qualidade do sistema municipal de saúde, proporção de habitantes com sorologia positiva para dengue, entre outros.

$\mathrm{Na}$ atual situação, é urgente e necessário o conhecimento dos fatores associados à infestação do vetor e à ocorrência da doença que, possibilitem o estabelecimento de estratégias de vigilância e de controle da dengue, de acordo com a realidade local. Um estudo desse tipo pode servir para identificar as áreas de infestação, densidade do vetor, sazonalidade ou 
períodos de aumento populacional do vetor. Em áreas onde o vetor não está presente, a vigilância entomológica é essencial para detectar novas introduções, antes do mosquito se dispersar.

O município de Santo André, local escolhido para realizar esse trabalho, faz parte da região do Grande ABC paulista e faz divisa com as cidades de São Paulo e de Santos. Esses municípios, que apresentam casos autóctones de dengue e focos do mosquito Aedes aegypti, estão interligados pelas estradas Via Anchieta e Rodovia dos Imigrantes, que cortam a região do Grande $A B C$ e facilitam o intercâmbio entre as cidades, situadas numa região de alto desenvolvimento econômico. Dessa forma, o fluxo migratório diário entre os municípios citados e Santo André pode ter contribuído para a dispersão do mosquito e a ocorrência de casos de dengue.

Os primeiros registros de focos do mosquito Aedes aegypti em Santo André, de acordo com dados do Setor de Controle de Zoonoses do Departamento de Vigilância à Saúde do Município, ocorreram em 1996, enquanto os primeiros casos importados de dengue foram registrados a partir de 1998.

A partir dessas informações foi realizado um estudo epidemiológico na cidade de Santo André visando descrever as condições locais relacionadas ao agravo. Assim, um estudo espacial e temporal dos registros da doença e da infestação do vetor tornou-se importante, pois pode contribuir para compreender a distribuição de ambos na cidade e para orientar ações de vigilância e de controle. 
O conhecimento das variações locais de temperatura, pluviosidade e umidade relativa do ar e sua relação com os índices de infestação do mosquito pode oferecer ao gestor de saúde condições de selecionar as informações, relativas a esses fatores ecológicos, que devem ser trabalhadas para o controle do vetor naquele município, pois o que é válido em uma região, pode não o ser para outra.

O estudo da população afetada pela doença, de acordo com seus atributos, descreve o quadro que pode levar a uma melhor caracterização da dengue na região, podendo-se a partir de então desenvolver ações preventivas baseadas nessas características.

A literatura não apresenta dados específicos e completos sobre esse agravo em Santo André, portanto a discussão dos aspectos epidemiológicos locais podem servir de orientação para as ações do Departamento de Vigilância à Saúde do município.

Levando-se em consideração o aumento do número de casos da dengue no estado de São Paulo e de sua ocorrência especifica na cidade de Santo André, enfatiza-se a importância da realização desse trabalho, que visou conhecer os fatores associados à infestação do Aedes aegypti e a ocorrência dos casos importados em unidades ambientais, possibilitando, assim, contribuir com o conhecimento da dinâmica da transmissão e a elaboração de sugestões de estratégias de prevenção, vigilância e controle, de acordo com a realidade local. 


\section{2 - OBJETIVOS}

\section{Geral}

- Descrever o perfil epidemiológico da dengue no município de Santo André, São Paulo.

\section{Específicos}

- Caracterizar os casos de dengue de acordo os atributos idade, sexo e grau de instrução da população.

- Discutir os coeficientes de incidência de dengue e a origem dos casos importados.

- Descrever a distribuição espacial e temporal da dengue e da infestação do Aedes aegypti em Santo André.

- Descrever as variáveis climáticas temperatura, pluviosidade e umidade relativa do ar e sua possivel correlação com a infestação do vetor no município.

- Descrever os principais criadouros do vetor no município.

- Contribuir com sugestões para orientação do serviço de vigilância e controle da doença em Santo André. 


\section{3 - MATERIAL E MÉTODOS}

\section{1 -Área de Estudo}

A história do município de Santo André está estreitamente relacionada à colonização da capital paulista. Desde a descoberta do Brasil, inúmeras expedições chegaram em nosso território, provenientes de Portugal e Espanha, e, dentre essas a que trouxe João Ramalho, que logo se estabeleceu no planalto paulista. Após a fundação de São Vicente, Martin Afonso de Souza oficializou o povoado de Santo André e nomeou João Ramalho Capitão-Mor do Campo de Piratininga, em 1532. Em 1553, Tomé de Souza, Governador Geral do Brasil, visitando o pequeno núcleo de civilização erguido por João Ramalho, outorgou a ele o predicamento de vila, e instalou a primeira Câmara Municipal em 8 de abril desse mesmo ano. No entanto, após alguns anos, devido aos constantes ataques de índios, a Câmara Municipal foi transferida para junto do Pátio do Colégio. Durante muitos anos, a vila de Santo André permaneceu no abandono. Com a passagem da São Paulo Railway por Santo André, ligando São Paulo a Santos, a localidade começou a ser procurada por novos moradores e, em 1889, surgiu o município com sede em São Bernardo e os distritos de Santo André, São Caetano, Ribeirão Pires e Paranapiacaba. Em 1938, a sede municipal foi transferida para o distrito de Santo André. O primeiro município a se desmembrar foi São Bernardo do Campo, em 30 de novembro de 1944, seguido por São Caetano do Sul, em 24 de dezembro de 1948. Em 30 de dezembro de 1953, Mauá e Ribeirão Pires também se desmembram e tornam-se municípios independentes. Em 1958, foi criado o município de Diadema, então desmembrado de São Bernardo do Campo e, em 1964, foi criado o município de Rio Grande da Serra, desmembrado de Ribeirão Pires (SUMÁRIO DE DADOS DE SANTO ANDRÉ 2001 ). Dessa forma, hoje 
temos esses sete municípios que compõem a chamada região do $A B C$ Paulista.

A cidade de Santo André encontra-se em uma altitude de 750 a 800 metros, latitude de $23^{\circ} 39^{\prime} 50^{\prime \prime} \mathrm{S}$ e longitude $46^{\circ} 32^{\prime} 18^{\prime \prime} \mathrm{W}$, com o referencial marco zero implantado na Praça IV Centenário. O Macrozoneamento Municipal, instituído pelo Plano Diretor-Lei Municipal No 7.333/95, divide o município que possui $174,38 \mathrm{Km}^{2}$ de superfície total em Área Urbana, com $66,45 \mathrm{Km}^{2}(38,11 \%)$ e Área de Expansão Urbana, com 107,93 $\mathrm{Km}^{2}$ $(61,89 \%)$ (Fig. 1).

O Plano Diretor estabelece que área urbana é aquela contida em um perímetro e definida pela grande quantidade de ruas com infra-estrutura, áreas para o assentamento da população, locais de trabalho e de compras, dotada de equipamentos para o atendimento de educação, saúde, lazer e cultura, assim como de serviços, tais como: transporte coletivo, coleta de lixo, correio, telefone e energia elétrica, criando dessa forma condições de vida e relacionamento social adequado. A zona de Expansão Urbana subdivide-se em seis regiões denominadas Zonas de Proteção Ambiental (ZPAs) devido ao fato de se encontrarem em locais de mananciais, cursos e reservatórios de água e outros recursos hídricos. Dessa forma, essa região deve ser preservada, tendo em vista a proteção dos recursos hídricos e o uso e ocupação do solo. Nessa área estão situadas duas bacias hidrográficas: a bacia do Rio Mogi e a bacia do Reservatório Billings, composta por duas sub-bacias formadas pelo Rio Grande e Rio Pequeno.

A vegetação é composta por mata secundária (floresta tropical úmida de altitude), que se mostra conservada em várias áreas, principalmente nas vertentes da Serra do Mar e nas nascentes dos Rios Grande e Pequeno. $\mathrm{Na}$ área mais urbanizada restaram matas em parques, como o do Pedroso, e pequenas manchas em locais com declividade mais acentuada (SUMÁRIO DE DADOS DE SANTO ANDRÉ 2001). 


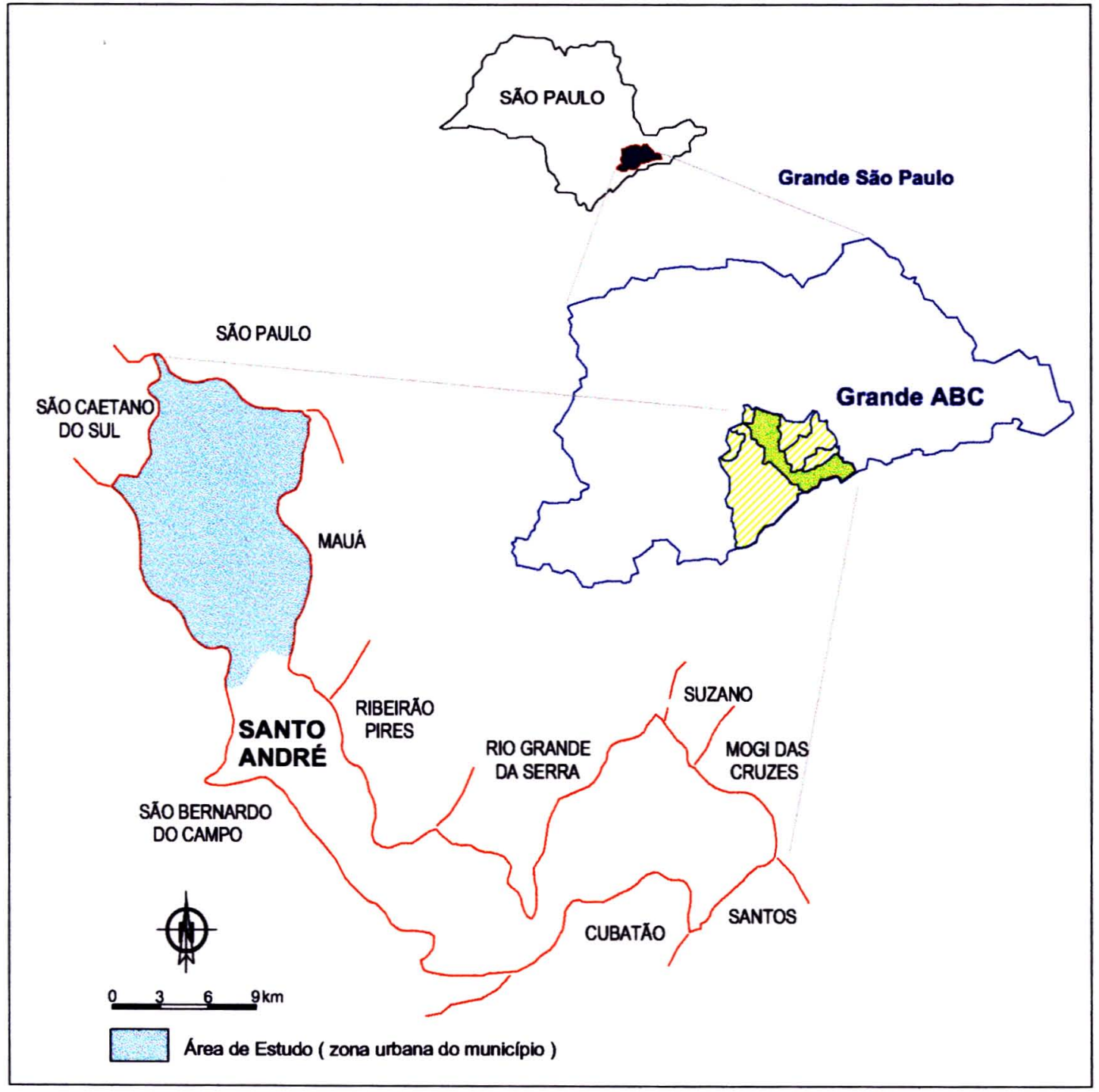

Figura 1 - Área de Estudo - Municipio de Santo André-SP (adaptado de Emplasa In: PMSA,1998) 
A cidade de Santo André, de acordo com o plano diretor do município, apresenta-se dividida em 117 bairros (Fig. 2) e 684 setores censitários (IBGE, 2000). A fim de estabelecer uma divisão compativel com o trabalho de vigilância epidemiológica da dengue, o Departamento de Vigilância à Saúde dividiu o município em 22 áreas em sua região urbana (Anexo). Essas áreas corresponderam às unidades geográficas cujos dados foram utilizados para a realização desse trabalho (Fig. 3). 


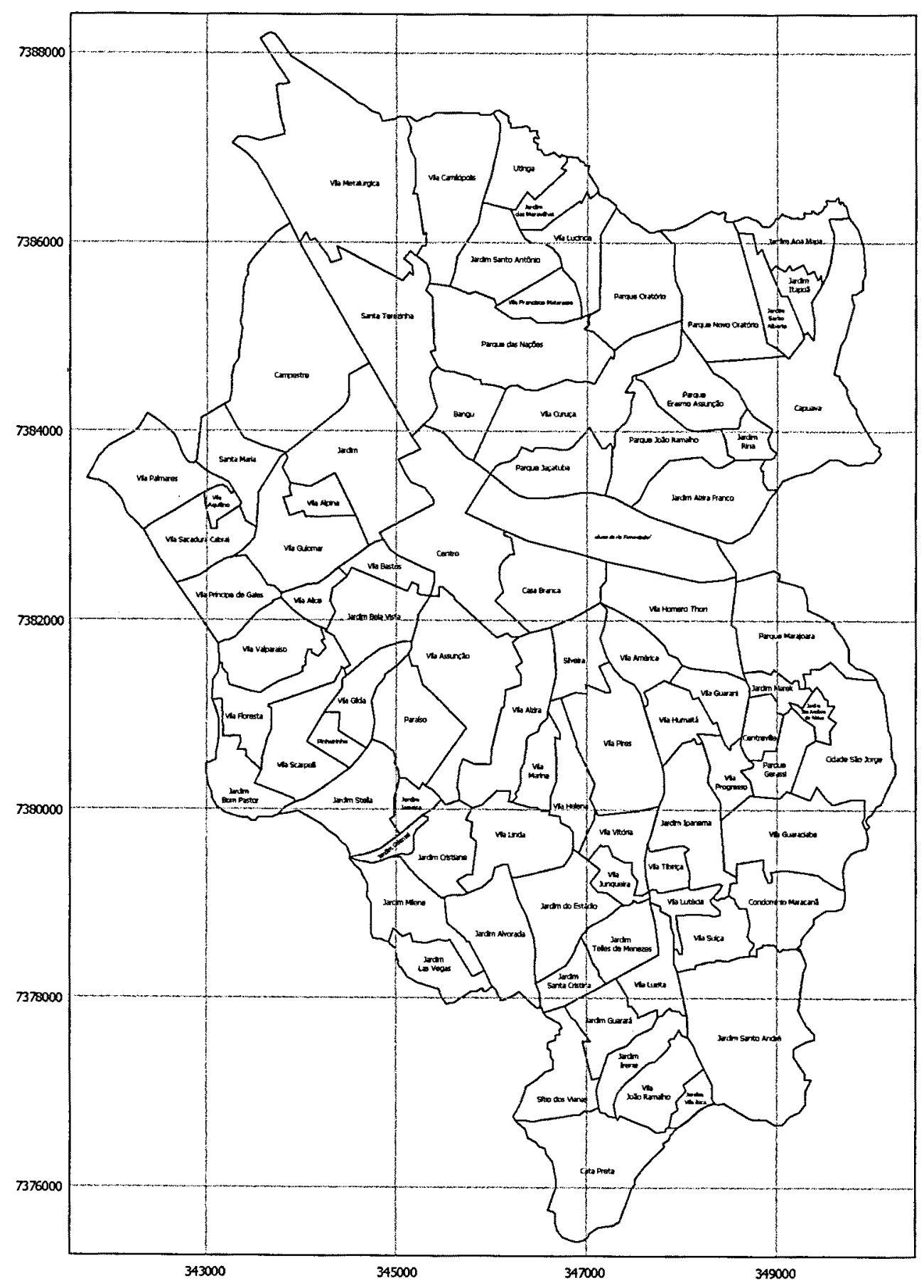

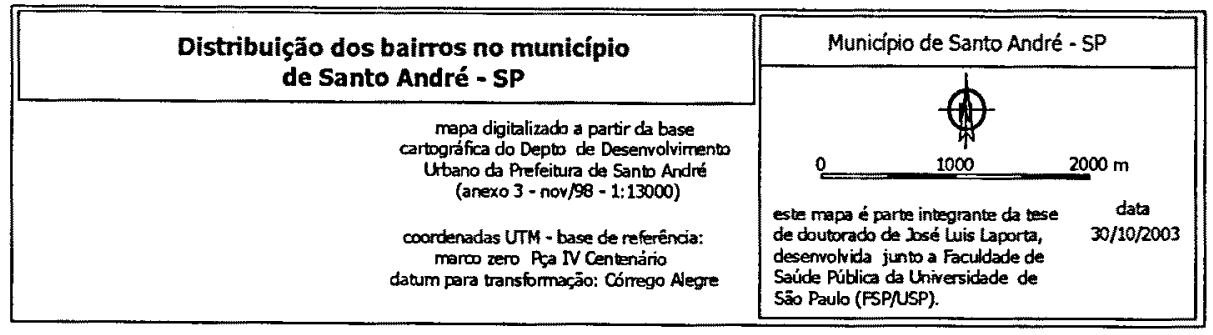

Figura 2 - Distribuição dos bairros no município de Santo André-SP 

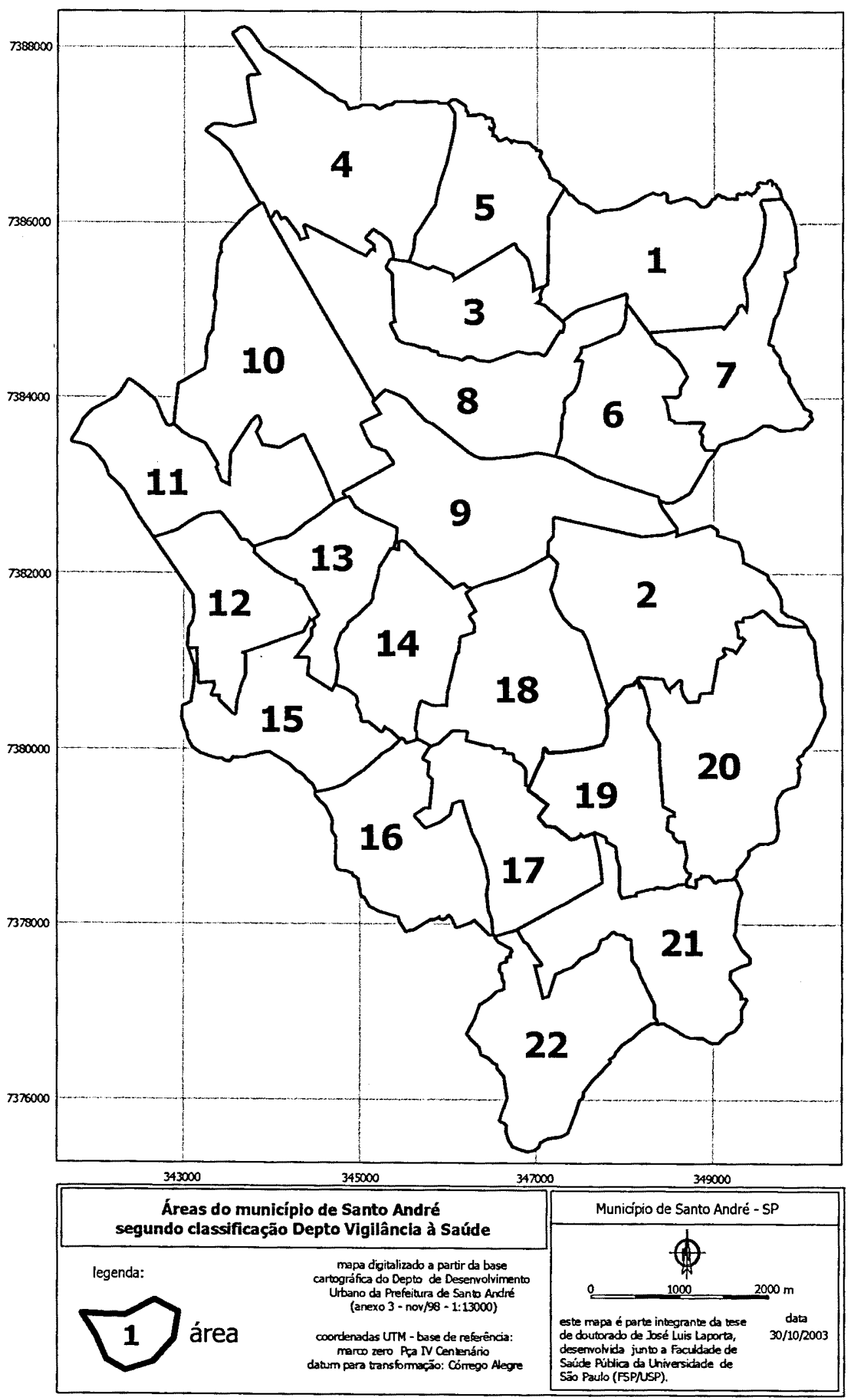

Figura 3 - Áreas do município de Santo André

sequndo classificação do Depto de Vigilância à Saúde 


\section{2- Infestação do Aedes aegypti}

Os cálculos de infestação do Aedes aegypti foram feitos a partir dos boletins de campo utilizados pelas equipes do Setor de Controle de Zoonoses do Departamento de Vigilância à Saúde do Município de Santo André e dos dados da Superintendência de Controle de Endemias do Estado de São Paulo (SUCEN), no período compreendido a partir de janeiro 2001 até julho de 2003. Os dados obtidos foram utilizados para cálculo do Índice de Infestação Predial, que relaciona o número de prédios com larvas do vetor e o número de prédios examinados. Os valores correspondentes ao total de larvas coletadas nos domicilios e os tipos de recipientes utilizados como criadouros no domicílio, foram obtidos a partir das planilhas elaboradas pelas equipes de agentes de saúde do município.

\section{3- Fatores Ecológicos}

Foram selecionados os fatores ecológicos temperatura, pluviosidade e umidade relativa do ar para verificar a existência de correlação com a infestação do mosquito. Com relação à temperatura utilizou-se a média dos valores médios, minimos e máximos mensais em graus Celsius. Para os dados de umidade relativa do ar foram utilizados os valores médios mensais expressos em porcentagem (\%). Os totais de precipitação mensais, em mm de $\mathrm{H}_{2} \mathrm{O}$, corresponderam aos valores de pluviosidade. O período abrangido correspondeu aos anos de 2001 a 2003 (até o mês de julho). Esses dados foram digitados em planilha EXCEL, versão 2000 (ANEXO).

Os valores de temperatura e de umidade relativa do ar foram obtidos junto à Companhia de Tecnologia de Saneamento Ambiental (CETESB). Os valores de precipitação foram obtidos junto à SEADE - EMPLASA e ao 
Sistema de Informação Geográfica de Recursos Hídricos (SIGRH) do estado de São Paulo.

Associações entre os fatores citados e o indice de infestação foram exploradas utilizando-se o coeficiente de correlação de Pearson ( $r$ ), cuja expressão abaixo calcula covariâncias entre pares de variáveis observadas separadamente durante os doze meses do ano.

$$
(r)=\frac{\sum_{i=1}^{12}\left(x_{1}-\bar{x}\right)\left(y_{1}-\bar{y}\right)}{\sqrt{\sum_{i=1}^{12}\left(x_{1}-\bar{x}\right)^{2} \cdot \sum_{i-1}^{12}\left(y_{1}-\bar{y}\right)^{2}}}
$$

\section{4- Casos de Dengue}

As informações sobre os registros de casos, bairro residente, local de procedência (importado ou autóctone) e a caracterização segundo a idade e sexo dos casos registrados foram obtidos através dos dados do cadastro SINAN, fornecido pelo Departamento de Vigilância à Saúde de Santo André e do Centro de Vigilância Epidemiológica Alexandre Vranjac, entre os anos de 1998 e 2002. Para o cálculo do coeficiente de incidência foram considerados os casos confirmados e foi utilizada a base 100.000 (número de casos/100.000 habitantes). 
Para os cálculos de incidência anual de dengue em Santo André foi utilizada a seguinte fórmula:

$C I=\frac{\mathrm{NC}}{\mathrm{P}} \times 100.000$

onde,

$\mathrm{Cl}=$ Incidência

$\mathrm{NC}=$ Número de Casos

$\mathrm{P}=$ População residente em Santo André no ano.

\section{5 - Dados Demográficos}

As informações demográficas, como tamanho da população, distribuição por sexo e faixa etária por bairro, foram coletadas através das publicações da Prefeitura do Município de Santo André (SUMÁRIO DE DADOS DE SANTO ANDRÉ, 2002) e do Instituto Brasileiro de Geografia e Estatística (IBGE 2000).

Os dados referentes aos valores sócio-econômicos e de saneamento da cidade foram obtidos através do Plano de Orçamento Participativo da Secretaria de Planejamento da Prefeitura de Santo André. Essas informações encontram-se disponiveis em forma de gráficos, tabelas e mapas, que foram utilizados para a verificação da distribuição espacial e temporal da infestação e da dengue. 


\section{6 - Distribuição espacial da dengue e da infestação}

Para o estudo da distribuição espacial da infestação pelo mosquito Aedes aegypti e da incidência da doença no município foi utilizado mapa representando a região urbana e dividido em 22 áreas nas quais o Departamento de Vigilância à Saúde dividiu a cidade. Esse mapa foi digitalizado a partir da base cartográfica $1: 10.000$, do Departamento de Desenvolvimento Urbano da Prefeitura de Santo André. O programa utilizado foi o TURBOCAD-2D. O mapa original contém os bairros nos quais o município é dividido. A partir desse registro, foi feito manualmente o trabalho de registrar as 22 áreas. De posse dos dados de incidência e de infestação, digitados em planilha EXCEL 2000, coloriram-se as áreas, utilizando como critério, no primeiro caso, ausência ou ocorrência de casos importados e presença ou ausência de focos, em domicílios, no segundo caso. 


\section{4 - RESULTADOS E DISCUSSÃO}

\section{1- Incidência de dengue em Santo André}

O primeiro caso de dengue no municipio de Santo André ocorreu em 1998. Tratava-se de uma pessoa do sexo feminino, 32 anos, moradora na área 1 do município, divisa com a cidade de São Paulo. A partir desse, todos os demais registros de dengue em Santo André, excetuando-se três casos em 2002, referiram-se a casos importados. Embora os registros tenham se referido a casos alóctones, deve-se considerar que, a partir desses casos, essa doença pode chegar a nível epidêmico em uma localidade, isto é, por meio de pessoas que contraem a doença em uma região $e$, ao retornar para a cidade onde vivem, trazem consigo o agente etiológico, no caso o vírus da dengue. Como o município de Santo André apresenta, também, infestação pelo mosquito Aedes aegypti, existe a possibilidade de transmissão e de ocorrência de casos autóctones. A investigação dos casos de dengue e da situação do municipio frente à infestação pelo vetor deve estabelecer prioridades para as ações do Departamento de Vigilância à Saúde.

De 1998 a 2002, periodo abrangido por esse estudo, verificou-se aumento da incidência anual da dengue. Em 1998, esse valor foi 0,31 por 100.000 habitantes e em 2002 atingiu 29 por 100.000 habitantes (Fig 4). 


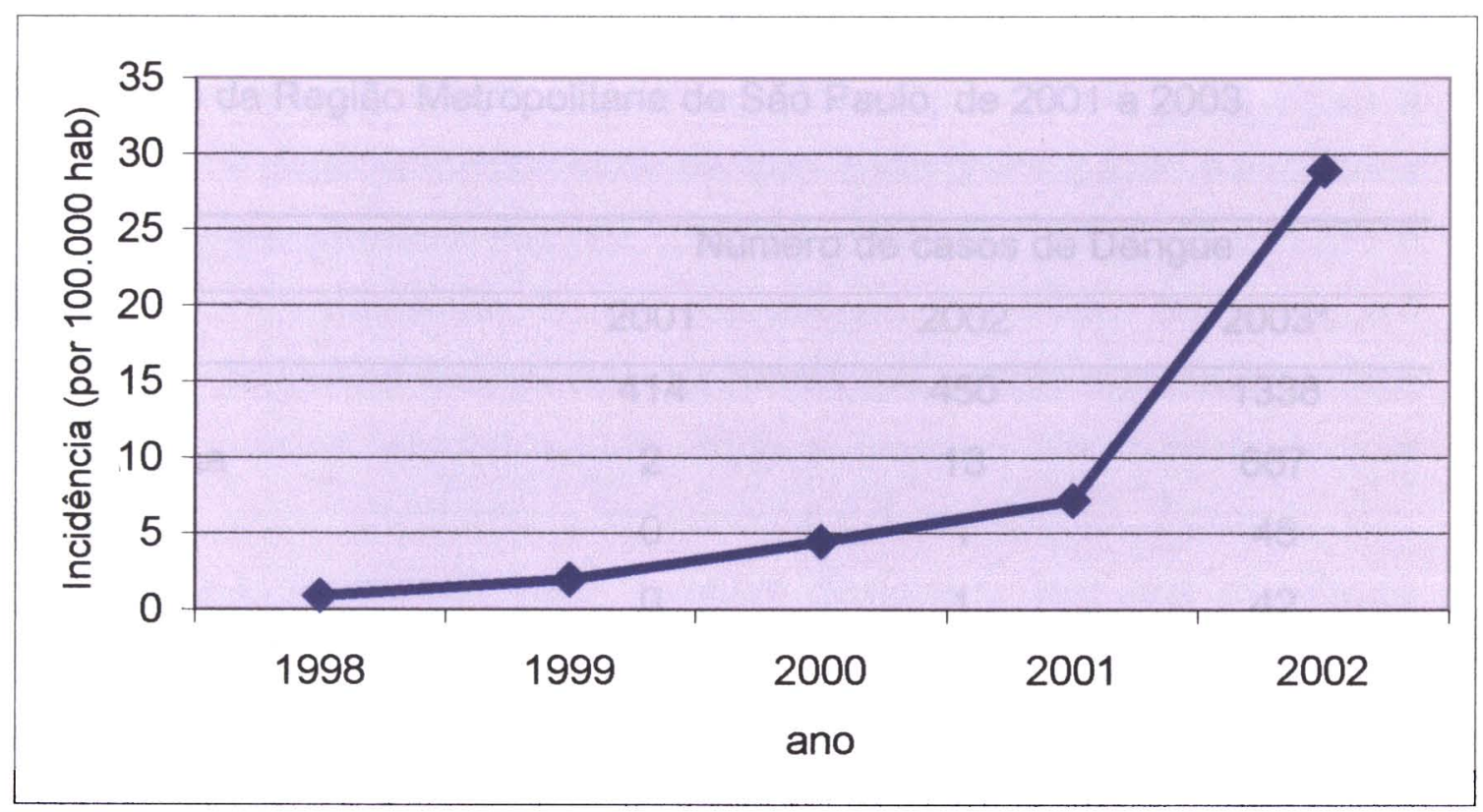

Fonte: Departamento de Vigilância à Saúde de Santo André - SINAN

Figura 4 - Incidência anual de dengue (por 100.000 habitantes) no municipio de Santo André, de 1998 a 2002.

Essa situação registrada em Santo André foi semelhante à observada em São Paulo, relativo aos casos de dengue, entre janeiro de 1995 e junho de 2000. Durante esse período, no município de São Paulo, foram registrados 1002 casos de dengue, sendo 1000 importados e somente dois autóctones, ocorridos em 1999 (NASCIMENTO 2001). A partir de 2001, no entanto, a cidade de São Paulo passou a apresentar aumento progressivo dos casos autóctones da doença, tendo sido registrados 321 casos em 2001, 430 em 2002 e 753 até novembro de 2003 (CVE 2003). Número crescente de casos autóctones de dengue, a partir de 2001, tem sido observado não somente na cidade de São Paulo, mas também em outros municípios que formam a região metropolitana dessa capital (Tab.2 ). 
Tabela 2 - Número de casos autóctones de dengue registrados em municípios da Região Metropolitana de São Paulo, de 2001 a 2003.

\begin{tabular}{lccc}
\hline & \multicolumn{3}{c}{ Número de casos de Dengue } \\
\hline Município & 2001 & 2002 & $2003^{*}$ \\
\hline Barueri & 414 & 450 & 1338 \\
Carapicuíba & 2 & 13 & 667 \\
Cotia & 0 & 1 & 45 \\
Diadema & 0 & 1 & 42 \\
Guarulhos & 13 & 113 & 280 \\
Itapevi & 1 & 519 & 2.160 \\
Jandira & 2 & 629 & 1884 \\
Osasco & 2 & 418 & 1767 \\
Santana de Parnaíba & 24 & 47 & 18 \\
São Bernardo do Campo & 0 & 8 & 1 \\
São Paulo & 321 & 430 & 753 \\
\hline
\end{tabular}

Fonte: CVE - SP

* Até novembro de 2003

Tomando-se, como exemplo, cidades do estado de São Paulo que passaram por situações epidêmicas de dengue, como foi o caso de Ribeirão Preto em 1991 (PONTES 1992) e São José do Rio Preto em 1995 (CAMPOS 1996 e CAMPOS e NATAL 1998), verifica-se que, ainda hoje, esses municípios continuam em situação preocupante, não só pelo risco da ocorrência de casos de dengue clássica, mas também pelo risco constante da ocorrência das formas hemorrágicas. Essa, também, deve ser a preocupação dos municípios da Região Metropolitana de São Paulo, dentre eles Santo André, já que essa região apresenta a mais alta densidade populacional do estado, uma intensa atividade econômica (SEADE 2003), 
casos autóctones de dengue e infestação pelo mosquito Aedes aegypti (CVE 2003).

Cidades com altas taxas demográficas têm sido alertadas sobre a possibilidade de alojar epidemia de dengue. Essa preocupação é justificada pois, segundo diversos autores (COSTA e NATAL 1998; GLASSER e GOMES 2000), epidemias de dengue tiveram seu início, em geral, em municípios com mais de 100.000 habitantes. De acordo com DONALISIO, 1998, as maiores incidências de dengue ocorrem em municípios com população entre cinqüenta e quinhentos mil habitantes. Por sua vez, CHIARAVALLOTI NETO, 1999, também destaca o fato dos municipios maiores serem responsáveis pela transmissão de dengue para os municipios menores e afirma o caráter urbano dessa doença.

O município de Santo André apresenta-se, portanto, em condições favoráveis quanto à ocorrência de casos epidêmicos, quando se leva em consideração o tamanho da população, pois esse municipio coloca-se entre os mais populosos do estado, com 649.000 habitantes (IBGE 2000). Além disso, deve-se levar em conta a ocupação humana na região do $A B C$, pois entre as cidades dessa região, em sua área urbana, praticamente inexiste barreira geográfica separando os municípios. Nas divisas municipais observa-se uma continuidade da paisagem urbana, com intenso deslocamento de pessoas e veículos. Assim sendo, o município de Santo André encontra-se em condições favoráveis, relativos aos aspectos mencionados, de apresentar casos autóctones. Essa situação é diferenciada daquela em que os municípios encontram-se isolados e cujos limites encontram-se em área rural. Os limites da cidade de Santo André com as cidades de São Paulo, São Caetano do Sul, São Bernardo do Campo e Mauá é urbano e, portanto, são locais onde podem proliferar focos do Aedes aegypti, mosquito responsável pela transmissão da doença.

A cidade de Santo André pode estar atravessando um momento semelhante ao de São Paulo entre 1995 e 2000, no que diz respeito aos casos importados. No entanto, sabendo-se que a partir de 2001 foram registrados casos autóctones nessa capital, é possível que a mesma 
situação possa se repetir em Santo André. Embora sejam vários os fatores que determinam a ocorrência de uma epidemia de dengue, essa analogia com a cidade de São Paulo, mesmo considerando uma incidência baixa da doença, pode servir de alerta para a vigilância municipal elaborar as estratégias de controle.

Assim, regiōes vizinhas ou fronteiriças, populosas e de grande densidade populacional apresentam dinâmicas de disseminação que estão inter-relacionadas, exigindo, portanto, trabalho conjunto entre os municipios envolvidos, no que diz respeito às ações preventivas da doença e de controle do vetor.

Considerando que, o aspecto demográfico da cidade de Santo André e de seus municípios vizinhos pode favorecer um possível risco da dengue se estabelecer de forma epidêmica, embora existam outros fatores que devam ser investigados, deve-se levar em consideração, também, que o valor da incidência de dengue encontrada em um determinado local deve ser compreendida como um indicativo de sua ocorrência. Assim, deve-se considerar que os sintomas de dengue clássica podem, muitas vezes, serem confundidos com os de outras doenças. Some-se a isso, ainda, os casos que não são notificados.

Vários estudos discutiram esse fato. DIETZ e col., 1990, em estudo realizado em Nova Iguaçu e Niterói, destacaram a dificuldade em identificar fator de risco para a dengue, devido, em alguns casos, ao fato da doença ser assintomática e à freqüente circulação de outras doenças virais, cujos sintomas assemelhavam-se aos da dengue. Por sua vez, RODRIGUEZFIGUEROA, 1995, encontrou uma taxa de 53\% de infecção assintomática de dengue em estudo realizado em Porto Rico. SERUFO e col., 1993, realizando, no estado de Minas Gerais, estudo soro-epidemiológico em pessoas com quadro febril não identificado, alertaram sobre a possibilidade de uma epidemia maior que a oficialmente conhecida. Já, LIMA e col., 1999, avaliando a magnitude da epidemia de dengue em Santa Bárbara do Oeste, encontraram prevalência 15 vezes superior ao da incidência de casos confirmados laboratorialmente durante a epidemia. Esses fatos, portanto, 
causam uma preocupação adicional quando se discute incidência de dengue, pois os valores encontrados podem ser inferiores à realidade local.

$O$ fato dos casos serem importados pode ser o ponto de partida de uma epidemia, o que mostra a importância do estudo desses casos, o que significa que seu acompanhamento e sua relação com as condições locais devem oferecer subsídios para a prevenção e controle da doença. $A$ vigilância epidemiológica local deve ter especial atenção em monitorar os casos, registrados, a sua distribuição geográfica, a identificação dos sorotipos circulantes, a sua origem e, também, fornecer aos serviços de atendimento médico-sanitário as informações a respeito da situação da doença na região, através de inquéritos sorológicos (DONALISIO 1998), já que existe a possibilidade, no caso de dengue, de transmissão silenciosa (CHEN e col. 1996).

\section{2 - Incidência de dengue em relação ao mês do ano}

Durante o período que compreendeu o estudo, os primeiros meses do ano foram aqueles em que ocorreu o maior número de casos alóctones, excetuando-se 1998, ano das primeiras ocorrências, registradas em novembro e dezembro. De 1999 a 2002, em Santo André, a incidência dos casos alóctones da doença foi maior nos primeiros meses do ano (Fig 5). 


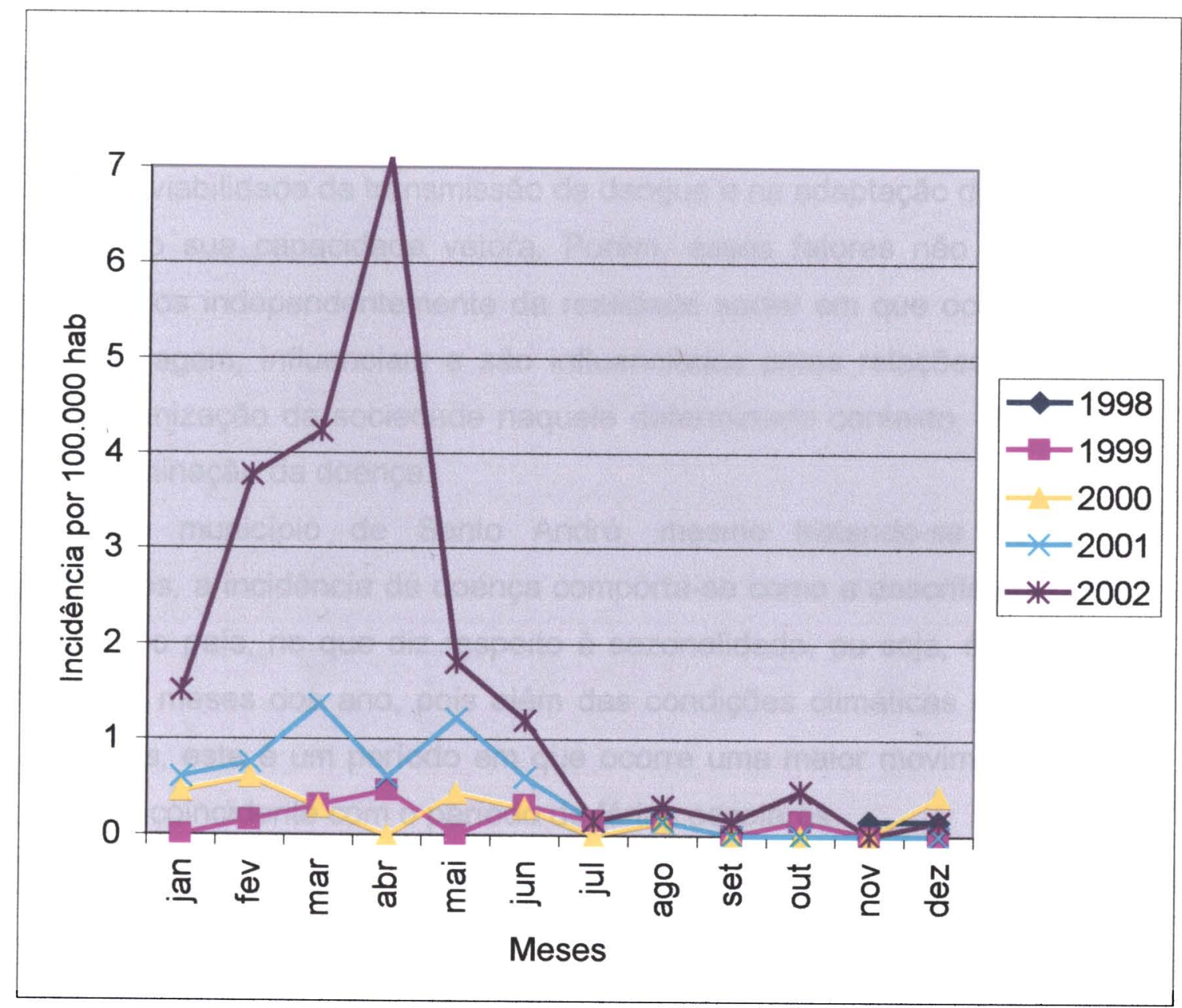

Fonte: Departamento de Vigilância à Saúde - Santo André

Figura 5 - Incidência mensal de casos alóctones de dengue (por 100.000 habitantes) no município de Santo André, de 1998 a 2002.

A distribuição sazonal da incidência de dengue foi observada por diversos autores. TEIXEIRA, 1999, comentou esse comportamento e destacou a incidência maior nos primeiros meses do ano, alcançando sua maior magnitude de março a maio, seguida de redução brusca a partir de junho. MARZOCHI, 1994, no estado do Rio de Janeiro, CHIARAVALOTINETO, 1999, em São José do Rio Preto, TEIXEIRA, 2001, em Salvador e SANTOS, 2003, em Maceió, destacaram a alta incidência da doença no período do verão e outono. Em outros países, como no México (SALAS e REYES 1994) e Bancoc, Tailândia (WATTS e col. 1987) essa distribuição sazonal também foi observado. Dados do Ministério da Saúde indicam que 
em todas as regiões do país (FUNASA 2003) a incidência de dengue é maior nos primeiros meses do ano.

É evidente que fatores ecológicos devem desempenhar importante papel na viabilidade da transmissão de dengue e na adaptação do mosquito, ampliando sua capacidade vetora. Porém, esses fatores não devem ser examinados independentemente da realidade social em que ocorrem, pois eles interagem, influenciam e são influenciados pelas relações humanas, pela organização da sociedade naquele determinado contexto, interferindo na disseminação da doença.

No município de Santo André, mesmo tratando-se de casos importados, a incidência da doença comporta-se como a descrita em outras regiōes do país, no que diz respeito à sazonalidade, ou seja, é maior nos primeiros meses dos ano, pois além das condições climáticas serem mais favoráveis, este é um periodo em que ocorre uma maior movimentação de pessoas, coincidente com o período de férias escolares.

\section{3 - Origem dos casos importados}

Em relação à origem, comparando-se as unidades federativas do país, verificou-se que a maioria dos casos de dengue detectados em Santo André, é proveniente do próprio estado de São Paulo com 50,4\%, seguido por Mato Grosso do Sul, Paraná, Bahia e Mato Grosso (Fig 6). 


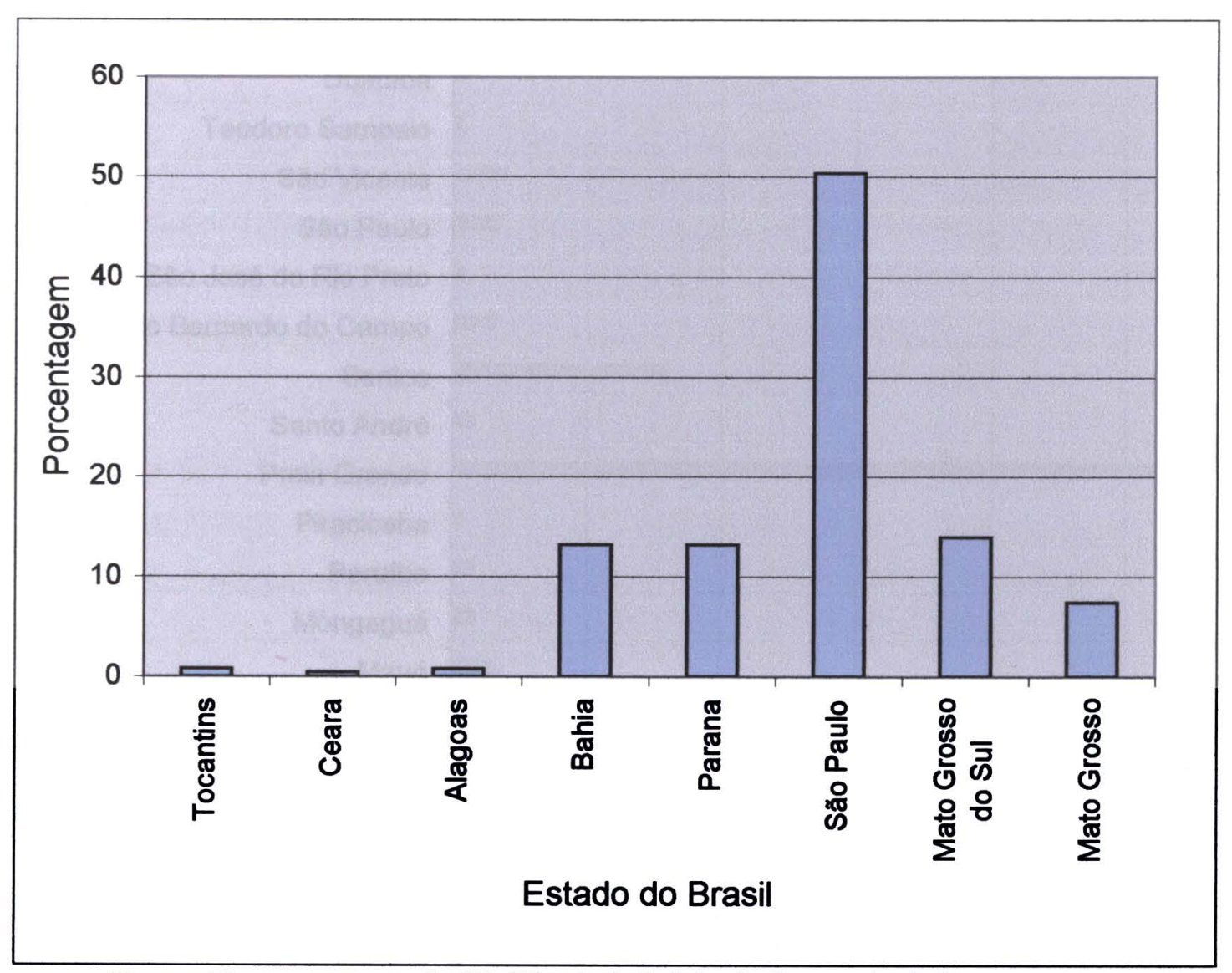

Fonte: Departamento de Vigilância à Saúde de Santo André - SINANW

Figura 6 - Freqüência dos casos importados de dengue em Santo André, de 1998 a 2002, segundo sua origem por estado brasileiro.

Quanto ao município de origem dos casos de dengue em Santo André, dentro do próprio estado, verificou-se que Praia Grande, no litoral de São Paulo, foi o que mais contribuiu para a ocorrência de casos importados em Santo André, com $52 \%$, seguido da cidade de Santos, também no litoral do Estado, com 18\% (Fig 7). 


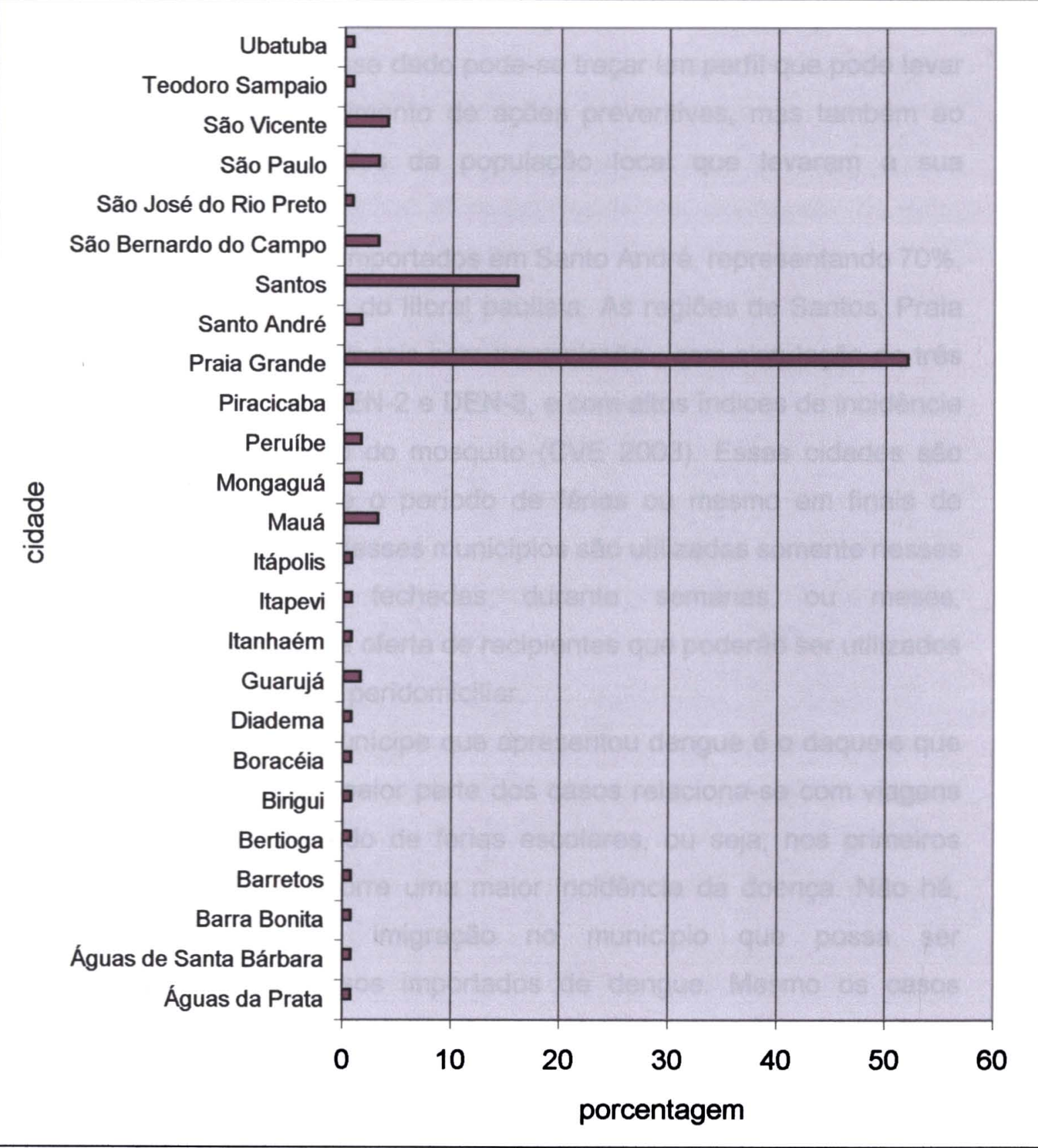

Fonte: Departamento de Vigilância à Saúde de Santo André - SINANW

Figura 7 - Distribuição dos casos importados de dengue em Santo André,segundo a cidade de origem no estado de São Paulo, de 1998 a 2002. 
A informação a respeito da origem dos casos importados é importante, pois a partir desse dado pode-se traçar um perfil que pode levar não somente ao estabelecimento de ações preventivas, mas também ao conhecimento das atividades da população local que levaram à sua ocorrência.

A maioria dos casos importados em Santo André, representando 70\%, foi adquirida em municipios do litoral paulista. As regiões de Santos, Praia Grande e São Vicente são locais com transmissão, com circulação de três tipos sorológicos, DEN-1, DEN-2 e DEN-3, e com altos índices de incidência da doença e de infestação do mosquito (CVE 2003). Essas cidades são muito freqüentadas durante o período de férias ou mesmo em finais de semana. Muitas das casas desses municípios são utilizadas somente nesses períodos, permanecendo fechadas durante semanas ou meses, aumentando, dessa forma, a oferta de recipientes que poderão ser utilizados como criadouros no espaço peridomiciliar.

Assim, o perfil do munícipe que apresentou dengue é o daquele que viaja para o lazer, pois, a maior parte dos casos relaciona-se com viagens realizadas durante o período de férias escolares, ou seja, nos primeiros meses do ano, quando ocorre uma maior incidência da doença. Não há, portanto, uma onda de imigração no municipio que possa ser responsabilizada pelos casos importados de dengue. Mesmo os casos provenientes de outros estados, de acordo com os dados da ficha epidemiológica, corresponderam também a viagens realizadas pelos munícipes, pois foi estabelecido como parâmetro, para esse estudo, os casos de dengue em moradores da cidade.

Esses resultados obtidos em Santo André são diferentes daqueles encontrados por NASCIMENTO, 2001, que estudando a origem dos casos importados na cidade de São Paulo, registrou que $24 \%$ eram provenientes da Bahia, $18 \%$ de Pernambuco e somente $19 \%$ do próprio estado de São Paulo.

Considerando-se a origem dos casos importados, é possivel que o município de Santo André pode ter apresentado casos de dengue causados 
pelos sorotipos 1, 2 e 3, em decorrência desses casos terem se originado, em sua maioria, na Praia Grande, município com circulação dos três tipos sorológicos do virus (CVE 2003). Além disso, como todos os casos são importados, cada região pode estar contribuindo com tipos sorológicos diferentes. Isso pode significar a possibilidade de ocorrência de uma epidemia na cidade.

Deve-se considerar também que a partir de 2002, a cidade de São Bernardo do Campo e a de Mauá apresentaram casos autóctones. Juntamente com os três casos autóctones ocorridos em Santo André, nesse ano, essa situação pode indicar a possibilidade de epidemia, uma vez que é muito grande o intercâmbio entre essas cidades, localizadas em região de intensa atividade econômica e industrial. Nesse sentido, para GÓMEZDANTEZ, 1995b, cidades médias e grandes, com atividades industriais, turísticas, comerciais, que são fonte de empregos e que concentram serviços médicos, constituem-se em focos potenciais de dispersão e introdução da infecção. O município de Santo André apresenta uma grande atividade industrial, comercial, uma boa rede de serviços médicos e um grande intercâmbio com outras cidades, portanto, a grande circulação de pessoas entre esses municípios aumenta a possibilidade da ocorrência de casos autóctones de dengue na região.

Outro aspecto a ser destacado é o fato dos limites entre essas cidades não serem definidos por barreiras geográficas, e sim por ruas ou avenidas que dão continuidade à paisagem urbana de um município para outro.

Embora em uma situação geográfica diferente, AVILÉS e col., 2001, relataram os primeiros casos de dengue na Argentina desde 1916; tratavase de quatro indivíduos que haviam viajado para o Brasil, Equador e Venezuela, países em que a doença ocorria, em 1997, de forma epidêmica, possibilitando transmissão em cidades como Rosário e Buenos Aires, o que mostra a importância de se manter vigilância ativa nas regiões limitrofes.

Por outro lado, deve-se destacar o fato da doença ainda não ter se estabelecido de forma autóctone no município, pois além dos casos 
importados, do grande intercâmbio entre as cidades vizinhas, da continuidade paisagística urbana nos limites das cidades e do tamanho das populações na região do $A B C$, verifica-se também a presença do vetor. Ou seja, embora o município tenha condições de alojar epidemia, esta ainda não se estabeleceu, o que pode indicar a existência de fatores ou barreiras, a serem investigados, que até o momento, provavelmente, impediram ou dificultaram o estabelecimento de casos autóctones.

\section{4 - Incidência em relação à idade}

Com relação à idade, observou-se que a incidência dos casos importados de dengue, relativa à 100.000 habitantes, foi maior em indivíduos na faixa etária superior aos 50 anos, em todos os anos, exceto em 2001, quando a maior incidência ocorreu na faixa dos 15 aos 49 anos. Em todos os anos a menor incidência ocorreu em individuos pertencentes a faixa etária até os 14 anos (Tab 3).

Tabela 3 - Incidência de dengue em Santo André relativo a 100.000 habitantes, segundo a faixa etária, de 1998 a 2002.

\begin{tabular}{cccccc}
\hline \multicolumn{7}{c}{ Ano } \\
\hline Faixa Etária & 1998 & 1999 & 2000 & 2001 & 2002 \\
\hline $0-14$ & 0 & 0 & 0 & 1,95 & 5,17 \\
$15-49$ & 0,27 & 2,41 & 4,30 & 8,10 & 25,61 \\
50 ou + & 0,80 & 2,80 & 4,80 & 5,59 & 29,60 \\
\hline
\end{tabular}

Fonte: Departamento de Vigilância à Saúde-Santo André - SINAMW 
Durante o período estudado, verificou-se aumento da incidência de casos importados em cada uma das faixas etárias, ou seja, a incidência foi aumentando a cada ano (Fig 8).

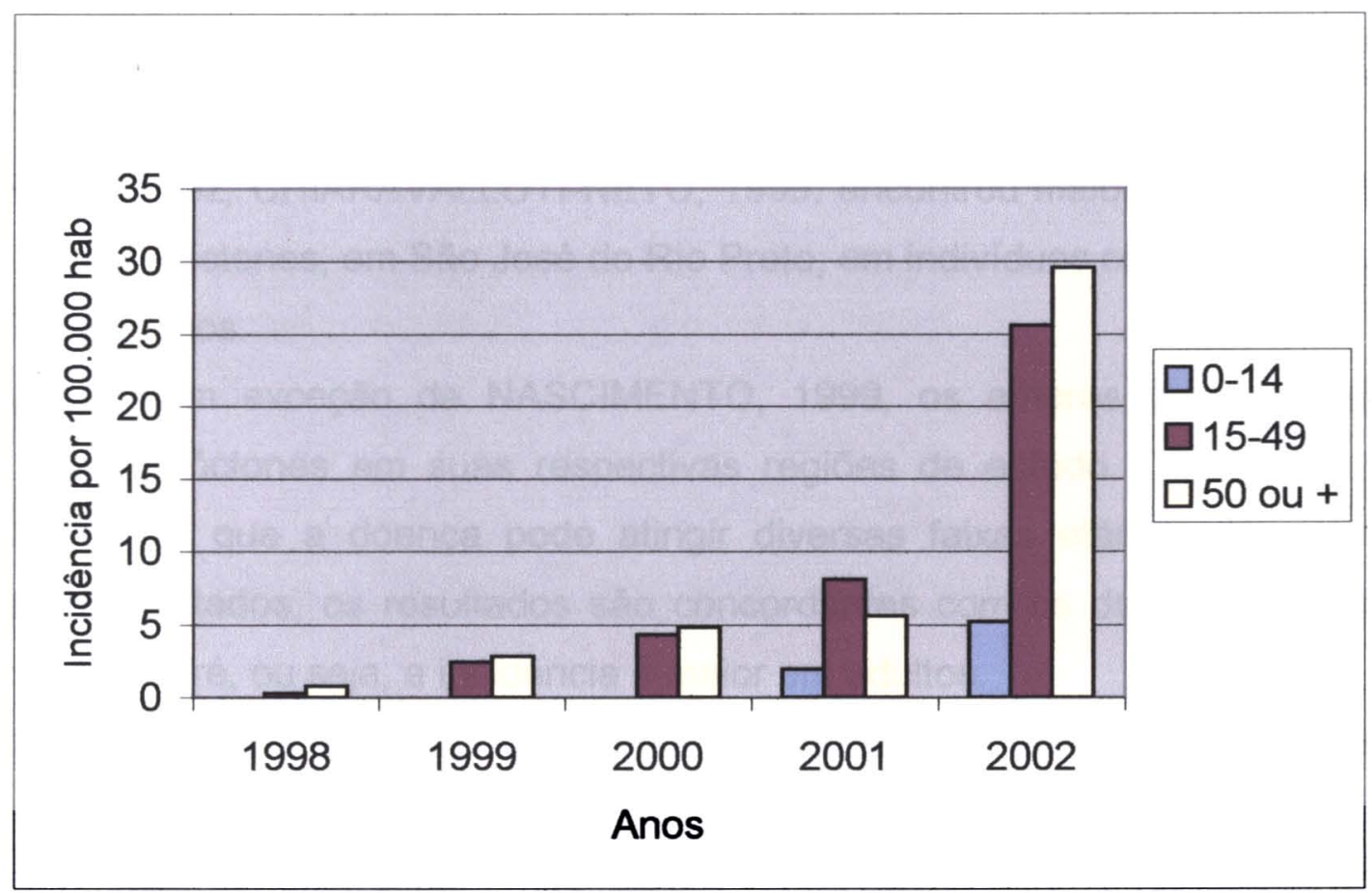

Fonte: Departamento de Vigilância à Saúde - Santo André - SINAMW

Figura 8 -Incidência de casos alóctones de dengue (por 100.000 hab.) no município de Santo André, segundo a faixa etária, de 1998 a 2002.

Estudando a distribuição por faixa etária de casos importados de dengue na região metropolitana de São Paulo, NASCIMENTO, 2001, encontrou maior incidência em indivíduos na faixa dos 20 aos 59 anos. Já TEIXEIRA, 2001, estudando a incidência de casos autóctones de dengue em Salvador, encontrou os maiores valores na faixa dos 20 aos 29 anos nos três primeiros anos de estudo, e, após esse período, os maiores valores foram encontrados em indivíduos com idade inferior a 10 anos. Por sua vez, VASCONCELOS e col, 2000, estudando a epidemia em Prado e Ipupiara, 
Bahia, registraram maior incidência na faixa etária dos 45 aos 54 anos, resultados esses diferentes dos encontrados por ROSA e col, 2000, em Belém, cujos maiores valores de incidência de casos autóctones ocorreu na faixa acima de 55 anos. DIETZ, 1990, estudando a distribuição da dengue em Nova Iguaçu no Rio de Janeiro, encontrou a maior taxa entre os 31 e 45 anos. No Acre, LOBATO e col, 2002, encontraram a maior incidência na faixa dos 15 aos 49 anos. Em Maceió, SANTOS, 2003, encontrou predomínio na faixa acima de 50 anos nos anos de 1997, 1998, 2001 e 2002 e maior incidência na faixa dos 15 aos 49 anos nos anos de 1999 e 2000. Por sua vez, CHIARAVALLOTI-NETO, 1999, encontrou maior incidência de casos autóctones, em São José do Rio Preto, em indivíduos com idade entre 30 e 59 anos.

Com exceção de NASCIMENTO, 1999, os autores mencionaram casos autóctones em suas respectivas regiões de estudo. Dessa forma, verifica-se que a doença pode atingir diversas faixas etárias, mas, nos estudos citados, os resultados são concordantes com os da pesquisa em Santo André, ou seja, a incidência é maior em adultos.

Deve-se observar, no entanto, a baixa incidência de casos importados, em Santo André, na faixa até os 14 anos. Salienta-se que, para se adquirir dengue, depende-se, dentre vários outros fatores, de exposição. Considerando que indivíduos dessa faixa etária permanecem um bom tempo no domicílio e considerando, também, que a maioria dos casos registrados em Santo André é importada de regiões utilizadas para o lazer, como os municipios do litoral paulista, a baixa incidência em jovens e crianças pode ser devida a fatores que devem ser investigados, como, por exemplo: os sintomas da dengue podem ser confundidos com os de outras doenças febris, a doença pode ser assintomática, o tratamento pode ter sido realizado sem consulta médica ou não ter sido notificado pela familia ao Centro de Saúde. Com isso, a subnotificação, nessa faixa etária, pode ser expressiva, em virtude do quadro clínico ser confundido com muitas viroses febris, ou por ser considerada pela população como uma virose benigna, o que nem sempre exige busca de atenção médica (TEIXEIRA 1999). Nesse sentido, 
DIETZ 1990, cita a diferença de notificação em Porto Rico em 1977, quando casos de sarampo e de gripe ocorreram durante a epidemia de dengue. Já em 1986, a Organização Mundial da Saúde (WHO) alertava sobre a existência de casos assintomáticos de dengue. Por sua vez MARZOCHI, 1994, considera que, sempre haverá um grande número de indivíduos assintomáticos, quer a situação seja epidêmica ou não.

Embora a maior incidência dos casos importados no município tenha ocorrido na população adulta, o que é concordante com os autores citados, não se deve desprezar os resultados referentes à população de menor faixa etária. Assim, os indivíduos que se encontravam em faixa etária acima dos cinqüenta anos representaram aquela com maior incidência da doença, no municipio de Santo André.

\section{5 - Incidência relativa ao Sexo}

Com relação ao sexo, observou-se que a incidência dos casos de dengue em Santo André não mostrou uma predominância em relação a esse atributo (Tab 4 e Fig 9).

Tabela 4 - Incidência de casos importados de dengue (por 100.000 habitantes) em Santo André, segundo o sexo, de 1998 a 2002.

\begin{tabular}{lccccc}
\hline & \multicolumn{5}{c}{ Ano } \\
\hline Sexo & 1998 & 1999 & 2000 & 2001 & 2002 \\
\hline Masculino & 0 & 2,9 & 3,2 & 5,4 & 20,6 \\
Feminino & 0,6 & 1,2 & 3,6 & 5,9 & 20,2 \\
\hline
\end{tabular}




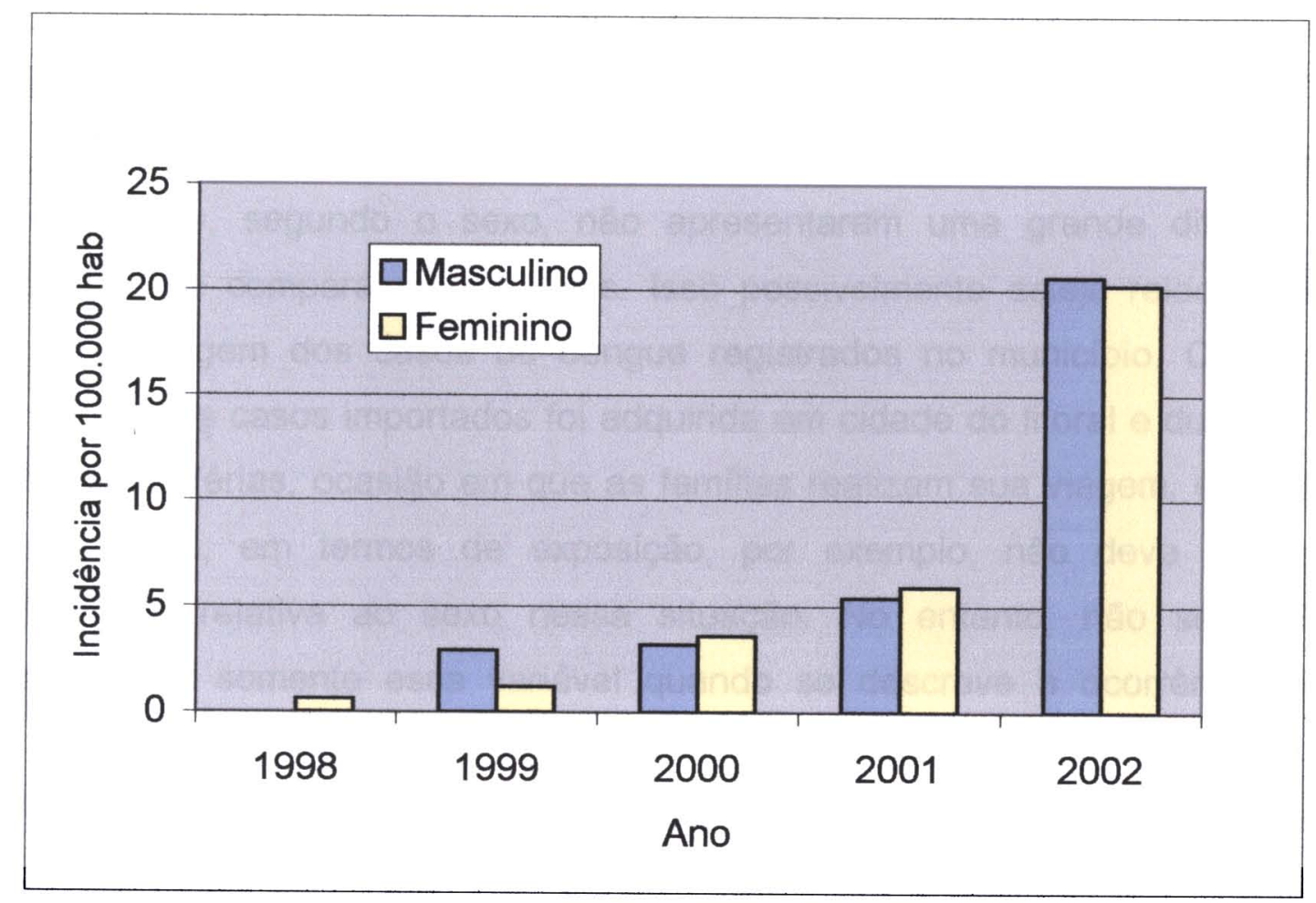

Fonte: Departamento de Vigilância à Saúde - Santo André - SINAMW

Figura 9 - Incidência de casos importados de dengue (por 100.000 habitantes) em Santo André, segundo o sexo, de 1998 a 2002.

Diversos autores observaram, em seus estudos, uma incidência maior da doença em indivíduos do sexo feminino (VASCONCELOS 2000, LOBATO 2002, BASTOS 2002, ROSA 2000, SANTOS 2003). De um modo geral, a mulher, por viver mais tempo no domicílio e no peridomicílio, tem um maior grau de exposição, o que facilita a transmissão (VASCONCELOS e col. 1993, GÓMEZ-DANTEZ 1995). Outros autores, no entanto, encontraram incidência maior em homens, por representarem a população economicamente ativa e, portanto, com maior exposição. Essa possivel maior exposição e facilidade de transmissão não devem ser confundidas com suscetibilidade pois, de acordo com a Organização Panamericana de Saúde, 1996, a dengue ocorre independentemente de ser o homem ou a mulher suscetivel. Não se deve, também, considerar somente a exposição 
como a única causa da doença, já que a multicausalidade é uma das caraterísticas marcantes na transmissão de dengue. No entanto, em relação ao sexo, essa é uma variável importante a ser considerada.

Em Santo André os valores referentes à incidência dos casos importados, segundo o sexo, não apresentaram uma grande diferença quando se comparam seus totais. Isso possivelmente esteja relacionado com a origem dos casos de dengue registrados no município. Como a maioria dos casos importados foi adquirida em cidade do litoral e durante a época de férias, ocasião em que as famílias realizam sua viagem, é de se supor que, em termos de exposição, por exemplo, não deve ocorrer diferença relativa ao sexo nessa situação. No entanto, não se pode considerar somente essa variável quando se descreve a ocorrência de dengue, pois outras variáveis devem atuar sobre essa transmissão, interferindo na incidência da doença. É possível, portanto, que essa distribuição seja devido à origem dos casos importados, o que pode representar uma característica do município.

\section{6 - Distribuição de dengue segundo o grau de instrução}

Com relação ao grau de instrução, verificou-se que no município de Santo André, a maior parte dos indivíduos, representando $58 \%$ daqueles que adquiriram a doença, tem como formação o ensino fundamental(Fig 10). 


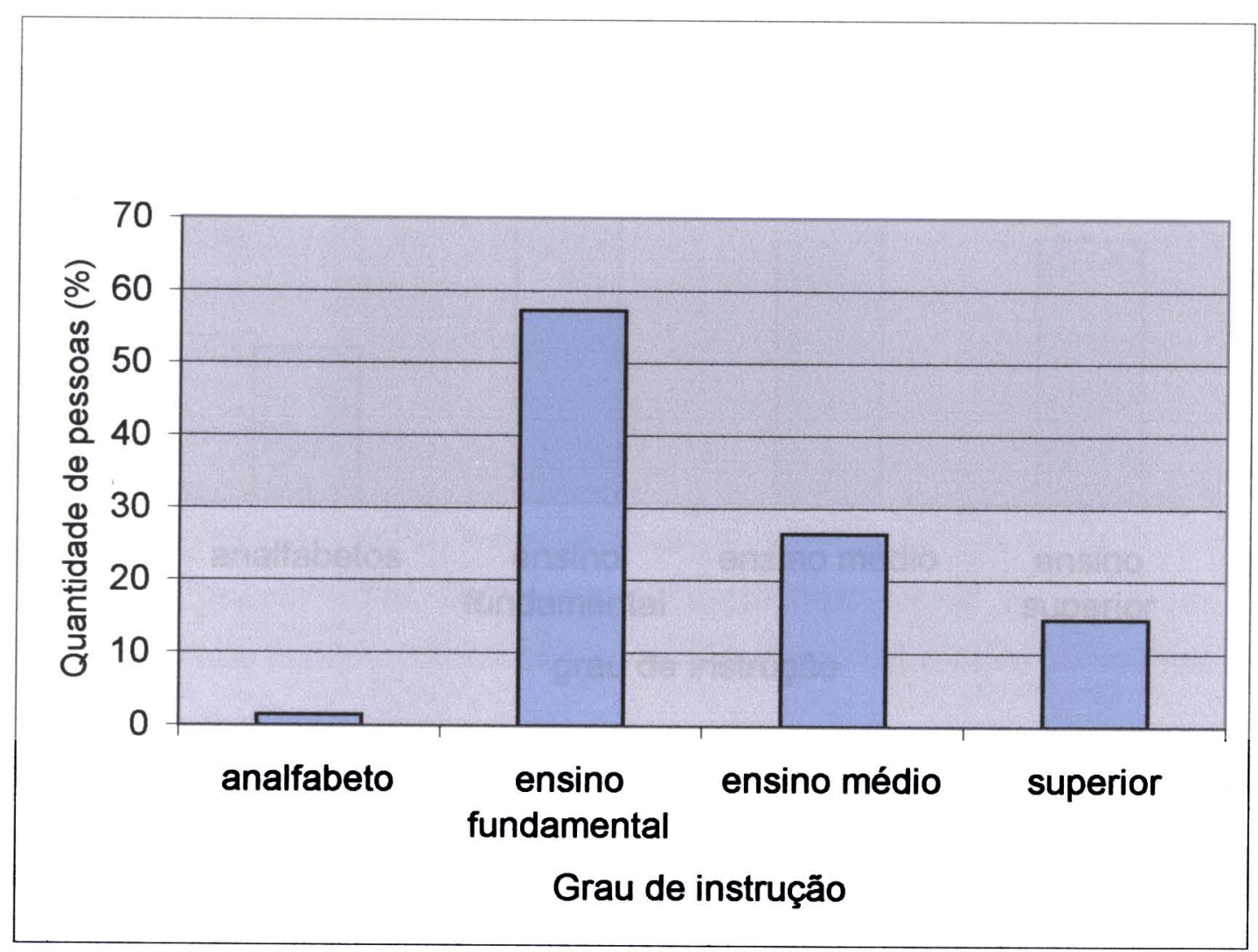

Fonte: Departamento de Vigilância à Saúde de Santo André - SINANW

Figura 10 - Distribuição dos casos importados de dengue em Santo André, segundo o grau de instrução, de 1998 a 2002.

Com relação à incidência dos casos importados relativos ao grau de instrução, foram utilizados os dados do ano de 2000 , baseado no censo do IBGE e nos dados do Departamento de Vigilância à Saúde. Os valores referentes ao grau de instrução dos residentes no município em 1998, 1999, 2001 e 2002 apresentavam-se incompletos. Assim, o resultado da incidência dos casos importados segundo o grau de instrução, para o ano de 2000, pode refletir uma situação existente no município de Santo André.

Dessa forma, verificou-se que a maior incidência da doença no ano de 2000 ocorreu em indivíduos com grau de instrução relativo ao ensino fundamental, enquanto a menor incidência ocorreu em indivíduos analfabetos (Fig 11). 


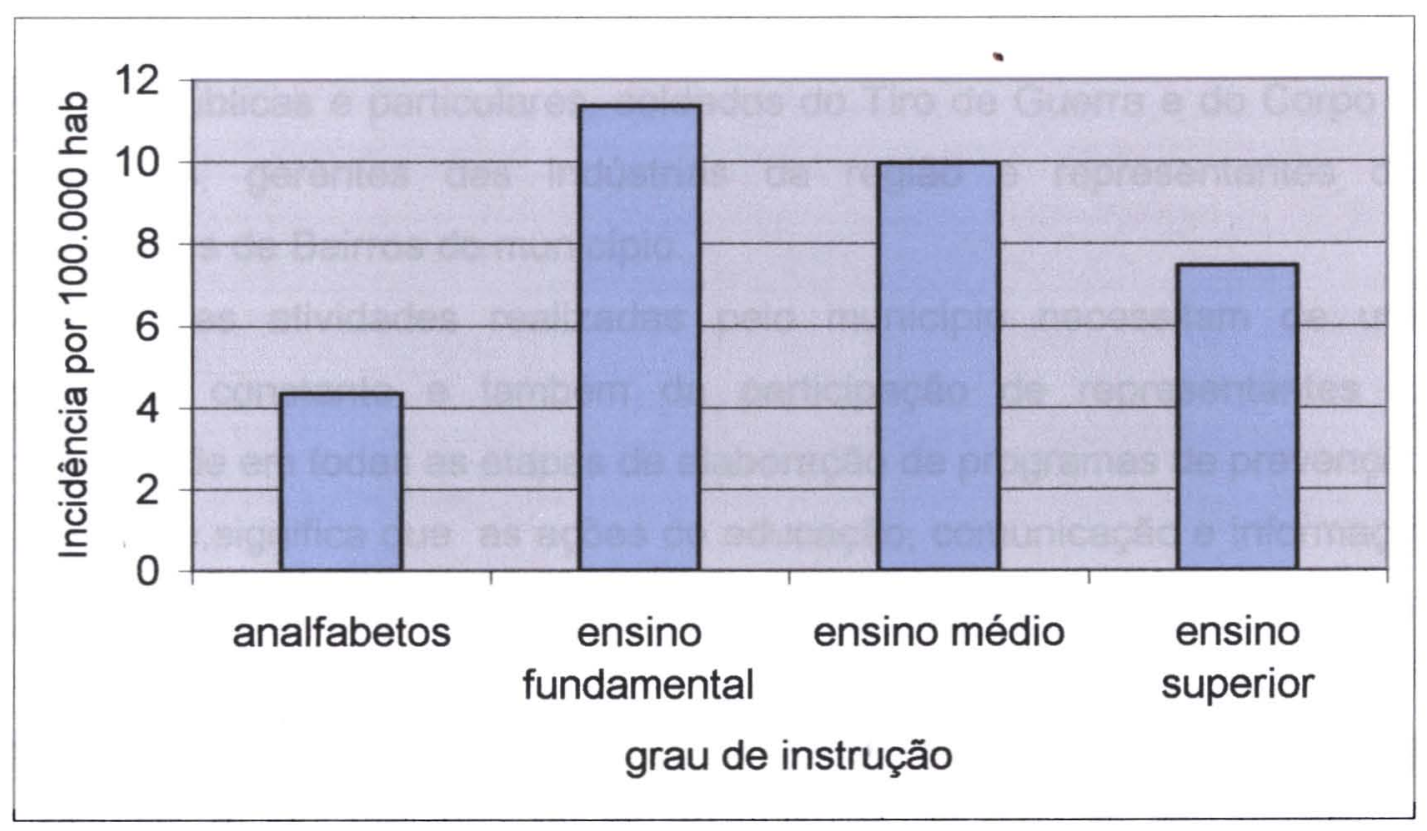

Fonte: Departamento de Vigilância à Saúde de Santo André - SINANW

Figura 11 - Incidência dos casos importados de dengue em Santo André, segundo o grau de instrução, por 100.000 habitantes em 2000.

0 trabalho desenvolvido para o controle de dengue utiliza como ponto de partida, principalmente, o controle do mosquito. A descrição dos sintomas também é amplamente apresentada pelos meios de comunicação. No entanto, ao se comparar a distribuição dos casos com o grau de instrução, verificou-se que a maior parte das pessoas que adquiriram a doença tem como formação o ensino fundamental, seguido por aquelas que têm o ensino médio e universitário. Ou seja, esses casos ocorreram em pessoas que podem compreender informações $e$ instruções escritas a respeito da doença. No entanto, isso não impediu a aquisição da doença nessa população. Estudos mostraram que a doença ocorre em municípios cuja população apresenta um conhecimento para evitar a transmissão (CHIARAVALOTI-NETO e col. 2000, 2002). Em Santo André, o Serviço de Educação em Saúde - IEC (Informação, Educação e Comunicação) tem desenvolvido, desde o ano de 2000, um trabalho que envolve treinamento para os agentes de zoonoses, empregados da ELETROPAULO, SEMASA 
(Secretaria do Meio Ambiente), Correios e Telégrafos, coordenadores das escolas públicas e particulares, soldados do Tiro de Guerra e do Corpo de Bombeiros, gerentes das indústrias da região e representantes das Sociedades de Bairros do município.

Essas atividades realizadas pelo município necessitam de uma avaliação constante e também da participação de representantes da comunidade em todas as etapas de elaboração de programas de prevenção.

Isso significa que as ações de educação, comunicação e informação não podem ser confinadas apenas à atuação dos agentes de saúde em cada residência, mesmo que associada a campanhas locais ou pontuais. $\dot{E}$ necessário que seja bem abrangente, com participação efetiva de setores da sociedade e do governo buscando a participação da comunidade no processo de prevenção e implementação de metodologias capazes de proporcionar mudança de comportamento.

\section{7 - Distribuição espacial e temporal dos casos importados}

Mesmo apresentando uma baixa incidência, todas as áreas de Santo André, entre 1998 e 2002, registraram casos de dengue. A distribuição espacial dos casos importados mostrou que, em todos os anos considerados, ocorreram casos de dengue na área 1, enquanto a área 2 foi a que apresentou a maior freqüência de casos (11\%). Em 1998, quando da ocorrência do primeiro caso importado no município, a dengue foi registrada em um morador da área 1 e em outro da área 10 (Fig. 12). Em 1999, nove áreas, $1,2,3,4,10,11,12,14$ e 19, registaram casos importados de dengue (Fig.13). Em 2000, a doença foi registrada em 8 áreas, 1, 7, 4, 6, 12,15, 21 e 22, sendo a área 2 a que mais contribuiu, com 7 casos (Fig. 14). Em 2001, somente as áreas 4,7,11 e 12 não registraram casos de dengue (Fig.15) e, em 2002 (Fig. 16), com exceção da área 14 do município, todas as demais apresentaram registro de casos importados (Tab 5). 
Tabela 5 - Número de casos importados e freqüência de dengue em Santo André de 1998 a 2002, segundo a área da cidade.

\begin{tabular}{|c|c|c|c|c|c|c|c|}
\hline \multirow{2}{*}{ Área } & \multicolumn{5}{|c|}{ Ano } & \multirow{2}{*}{ Total } & \multirow{2}{*}{$\%$} \\
\hline & 1998 & 1999 & 2000 & 2001 & 2002 & & \\
\hline 1 & 1 & 1 & 1 & 3 & 14 & 20 & 9,9 \\
\hline 2 & 0 & 1 & 7 & 3 & 12 & 23 & 11,5 \\
\hline 3 & 0 & 2 & 0 & 1 & 5 & 8 & 4,0 \\
\hline 4 & 0 & 1 & 1 & 0 & 8 & 10 & 5,0 \\
\hline 5 & 0 & 0 & 0 & 1 & 11 & 12 & 6,0 \\
\hline 6 & 0 & 0 & 1 & 3 & 5 & 9 & 4,5 \\
\hline 7 & 0 & 0 & 0 & 0 & 2 & 2 & 1,0 \\
\hline 8 & 0 & 0 & 0 & 1 & 8 & 9 & 4,5 \\
\hline 9 & 0 & 0 & 0 & 1 & 3 & 4 & 1,9 \\
\hline 10 & 1 & 1 & 0 & 0 & 6 & 8 & 4,0 \\
\hline 11 & 0 & 2 & 0 & 0 & 7 & 9 & 4,5 \\
\hline 12 & 0 & 1 & 1 & 1 & 2 & 5 & 2,5 \\
\hline 13 & 0 & 0 & 0 & 1 & 5 & 6 & 3,0 \\
\hline 14 & 0 & 1 & 0 & 2 & 0 & 3 & 1,5 \\
\hline 15 & 0 & 0 & 1 & 6 & 3 & 10 & 5,0 \\
\hline 16 & 0 & 0 & 0 & 2 & 8 & 10 & 5,0 \\
\hline 17 & 0 & 0 & 0 & 1 & 1 & 2 & 0,9 \\
\hline 18 & 0 & 0 & 0 & 2 & 8 & 10 & 5,0 \\
\hline 19 & 0 & 1 & 0 & 1 & 8 & 10 & 5,0 \\
\hline 20 & 0 & 0 & 0 & 1 & 3 & 4 & 1,9 \\
\hline 21 & 0 & 0 & 1 & 2 & 8 & 11 & 5,5 \\
\hline 22 & 0 & 0 & 3 & 2 & 11 & 16 & 7,9 \\
\hline Total & 2 & 11 & 16 & 34 & 138 & 201 & 100,0 \\
\hline
\end{tabular}

Fonte: Departamento de Vigilância à Saúde - Santo André 

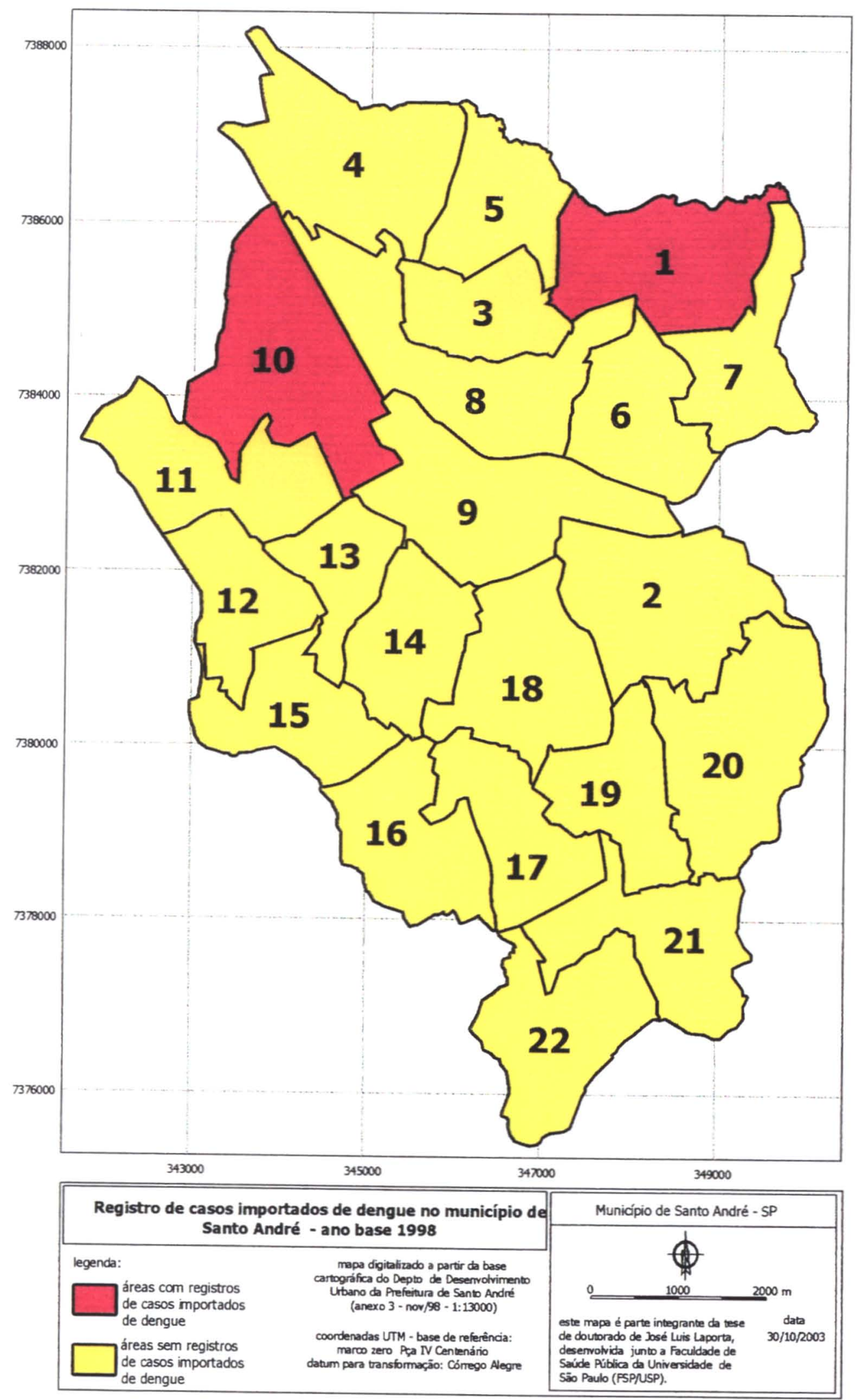

Figura 11 - Áreas com registros de casos importados de dengue no município de Santo André - ano base 1998 


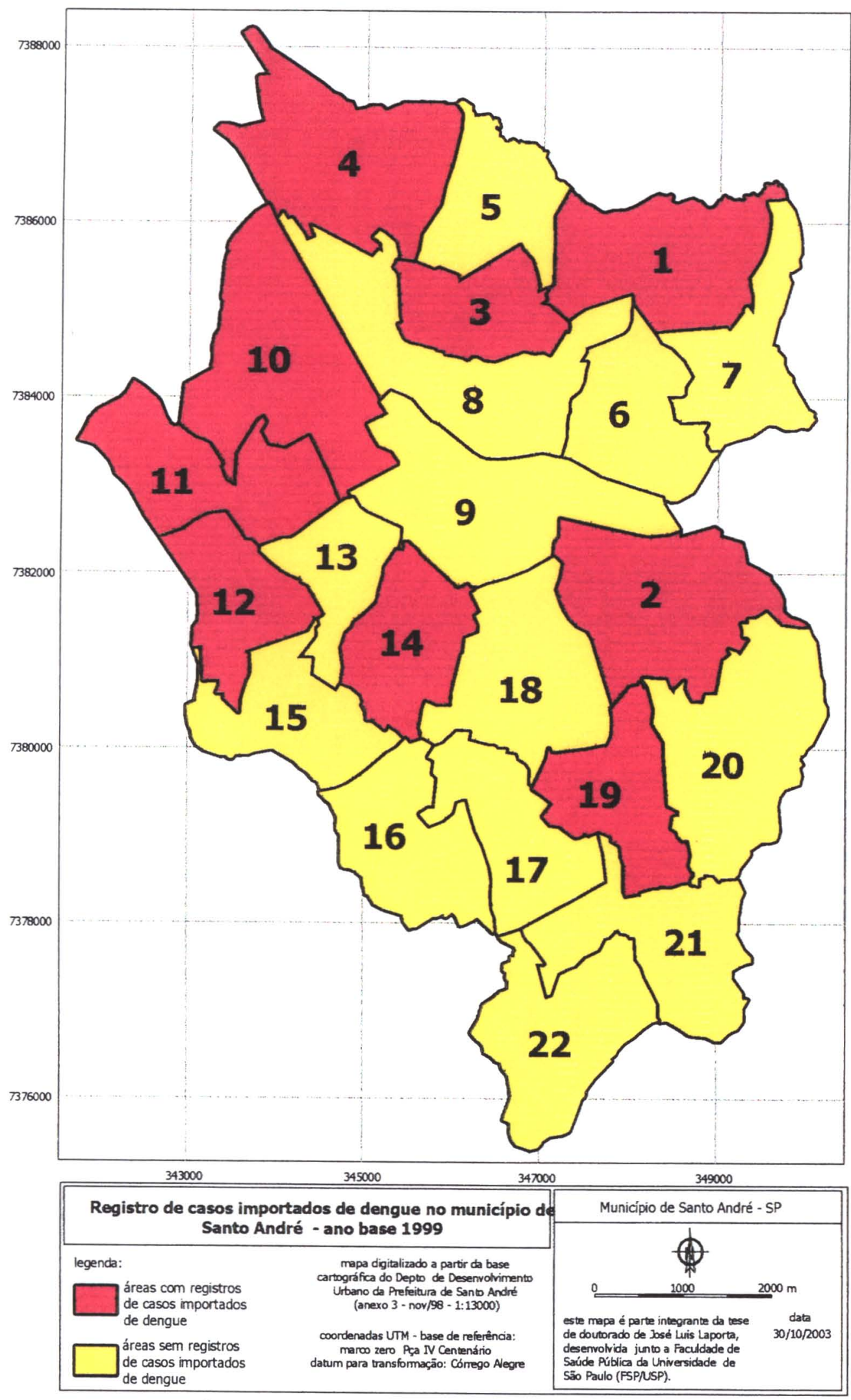

Figura 12 - Áreas com registros de casos importados de dengue no município de Santo André - ano base 1999 


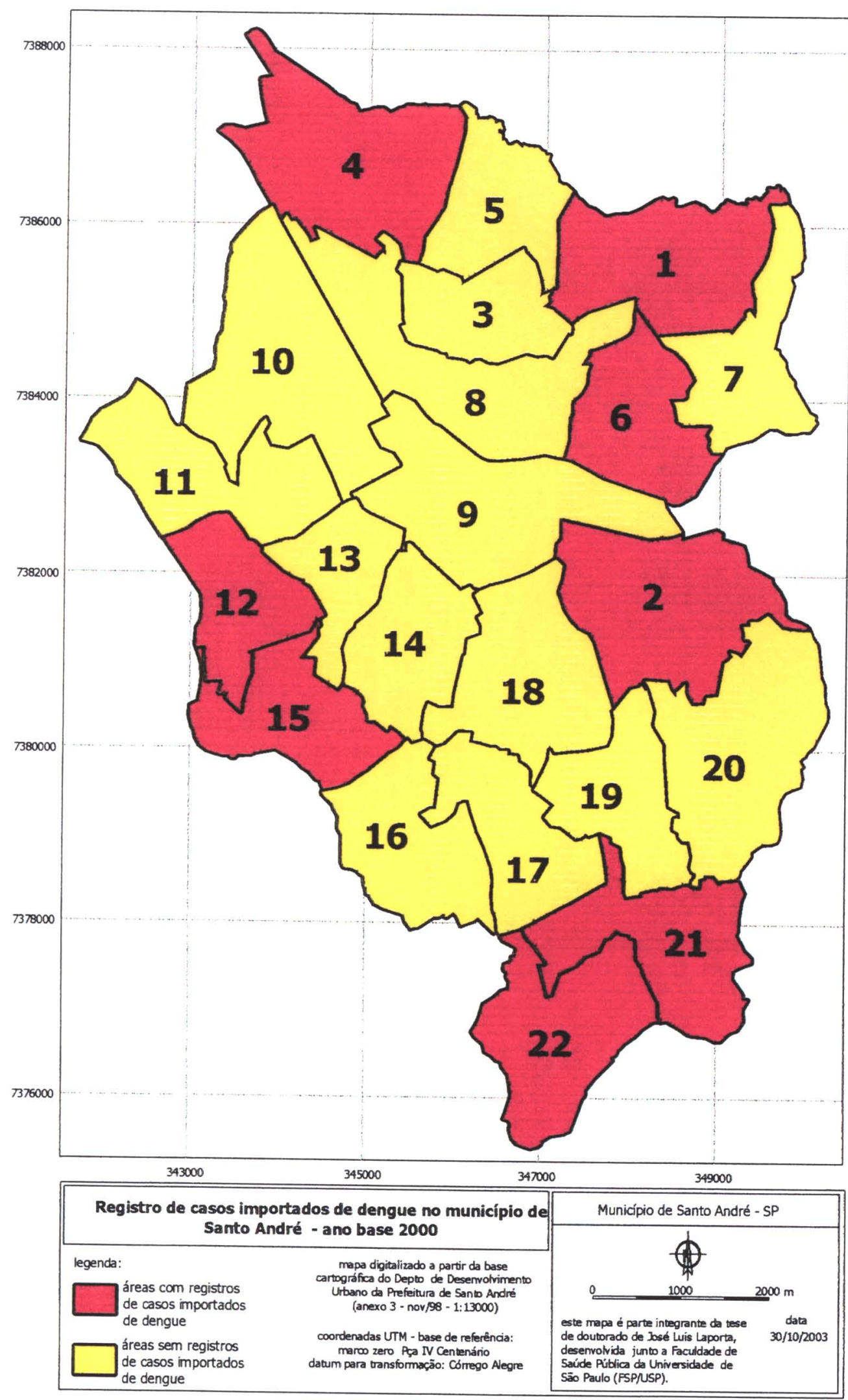

Figura 13 - Áreas com registros de casos importados de dengue no município de Santo André - ano base 2000 


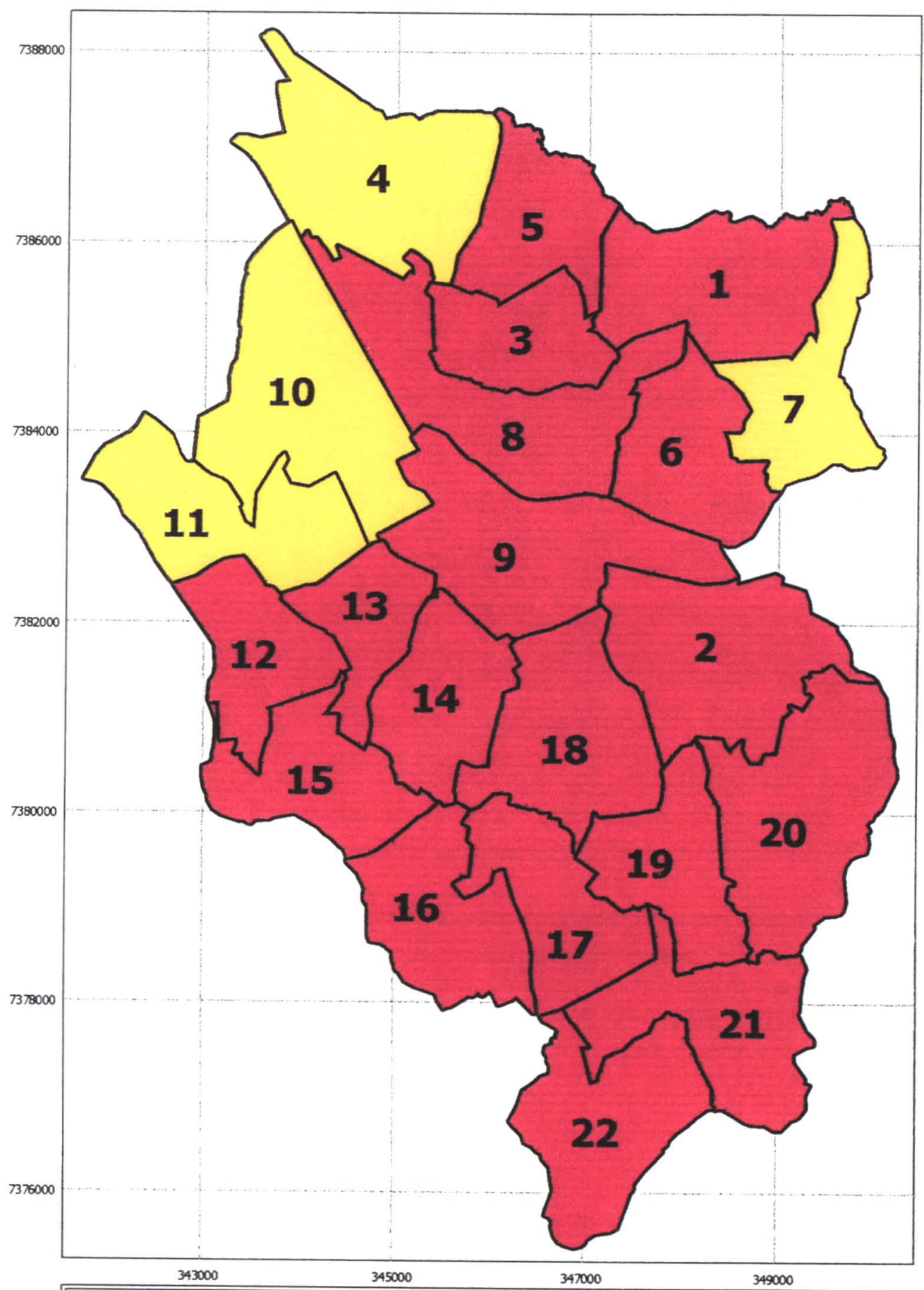

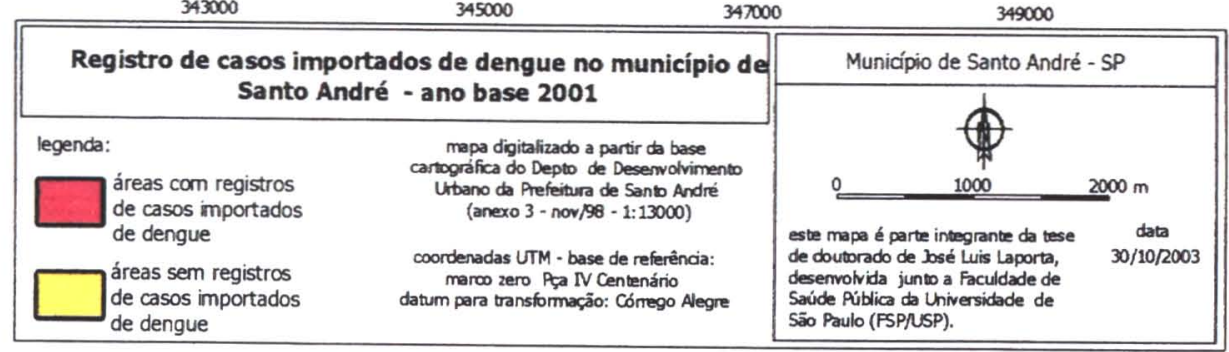

Figura 14 - Áreas com registros de casos importados de dengue no município de Santo André - ano base 2001 


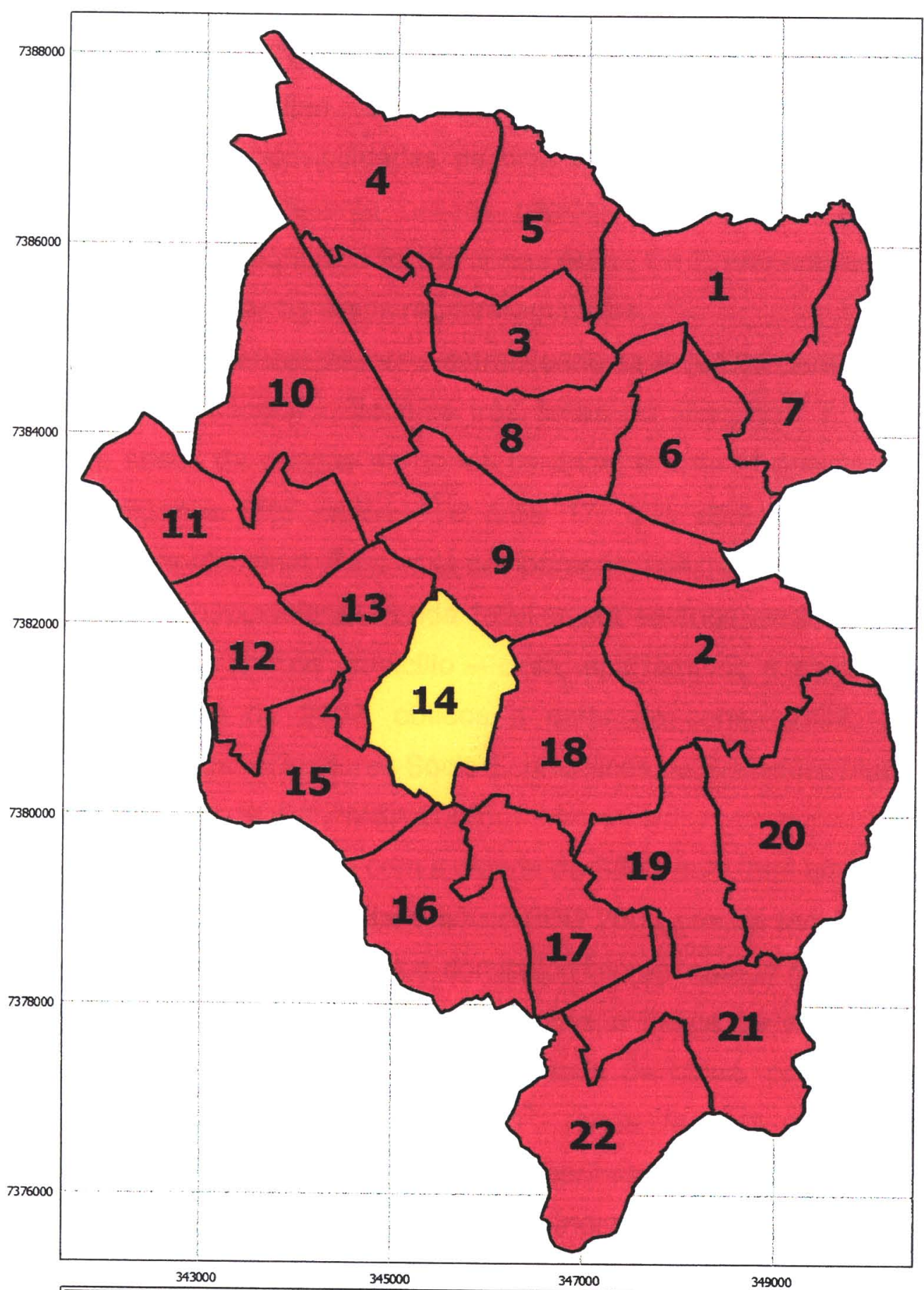

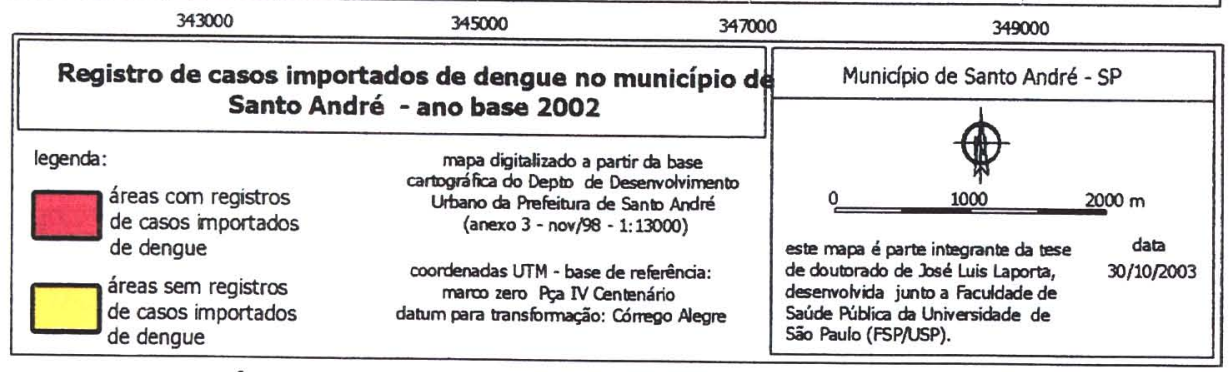

Figura 15 - Áreas com registros de casos importados de dengue no município de Santo André - ano base 2002 
Além do aumento do número total dos casos importados a cada ano, observou-se, em 2001 e 2002, um aumento do número dos casos em todas as áreas do município. Considerando-se essa distribuição, isso pode significar maiores possibilidades de ocorrência de epidemia, desde que o vetor encontre-se presente nessas regiões. Assim, embora possa ser observado que a freqüência foi maior nas áreas 1 e 2 , respectivamente, com $9,9 \%$ e $11,5 \%$, todas as áreas registraram casos.

Para caracterizar de forma estratificada as áreas da cidade e os casos registrados de dengue utilizou-se três áreas do município: a área' 1, que registrou casos de dengue em todos os anos; a área 2, que apresentou a maior freqüência dos casos e a área 17, que apresenta a de maior densidade populacional. Para essa comparação, utilizaram-se os parâmetros de densidade populacional, renda familiar em salários mínimos, índice de alfabetização e tipo de domicílio - casa, apartamento e aglomerações relativos ao ano de 2002, obtidos a partir do censo IBGE, 2000, da Coordenadoria de Indicadores Sócio-Econômicos da Prefeitura Municipal de Santo André (CIS-SOPP-PMSA 2003).

A área 1 faz fronteira com a cidade de São Paulo, tem uma densidade populacional de 11.684 habitantes $/ \mathrm{Km}^{2}$ (IBG 2000), renda familiar média de 4,1 salários mínimos, $98,8 \%$ dos domicílios representados por casas, $0,5 \%$ por apartamentos e $0,7 \%$ por aglomerações e indice de alfabetização de $94,4 \%$. A área 2 faz fronteira com a cidade de Mauá, possui densidade populacional de 7.875 habitantes $/ \mathrm{Km}^{2}$, renda familiar de 3,9 salários mínimos, $96,7 \%$ de residências representadas por casas, $2,4 \%$ por apartamentos e 0,9\% por aglomerações e índice de alfabetização de 93,9\%. A área 17 tem densidade populacional de $17.338 \mathrm{Hab} / \mathrm{Km}^{2}$, apresenta renda média familiar de 3,1 salários mínimos, $90,7 \%$ de índice de alfabetização e $93,7 \%$ de residências, $3,7 \%$ de apartamentos e $2,8 \%$ de aglomerações (ANEXO)

BARREIRA e col., 2000, discutiram a importância da estratificação de uma cidade para o controle de dengue. Para esses autores, a densidade populacional apresenta correlação positiva para o risco de dengue e uma 
maior incidência de dengue clássico apresenta correlação positiva para o risco de se adquirir dengue hemorrágico. Por sua vez, CHIARAVALOTINETO, 2001, não encontrou associação entre coeficiente de incidência de dengue $e$ as condições sócio-econômicas da população de 8 maiores cidades da região de São José do Rio Preto. Estudos realizados por CAMPOS, 1995 e CAMPOS e NATAL, 1998, em São José do Rio Preto mostraram haver associação entre incidência de dengue e os setores censitários, segundo os niveis sócio-econômicos, isto é, verificou-se uma incidência de dengue mais baixa nos setores de maior renda e de maior nivel de instrução. A Organização Panamericana de Saúde, 1991, sugeriu uma abordagem de estratificação que leva em consideração o nível sócioeconômico.

CHIARAVALLOTI-NETO, 1999, considerou que a dengue é predominantemente uma doença urbana, e, ainda que, é pelas cidades maiores que se inicia a transmissão. Portanto, os fatores ligados à transmissão da doença devem ser encontrados no próprio local. Isso envolve as características das grandes cidades, como saneamento, condições de habitação, atendimento à saúde e educação.

GÓMEZ-DANTEZ e col., 1995a, consideraram a densidade populacional como fator fundamental para definir o padrão de transmissão. Já, LIMA e col, 1999, ao analisar prevalência da dengue em zona urbana do estado de São Paulo não encontraram relação entre os valores encontrados e o local de moradia da pessoa. SANTOS, 2003, em Maceió, não encontrou relações entre a incidência de dengue e fatores sócio-econômicos da cidade, demonstrando a ocorrência de uma maior incidência ora em bairros com elevado padrão econômico e social, ora em ambiente bem degradado e ocupado por população pobre.

Em virtude desses estudos e concordando com o assinalado pela OPAS, 1991, deve-se caracterizar estratificadamente os fatores de acordo com a realidade local que vise as ações preventivas e de controle.

Essa estratificação que busque encontrar um fator ou mais fatores que favoreçam localmente a transmissão de dengue foi objeto do estudo dos 
autores citados, visando estabelecer uma estimativa de risco de dengue. No entanto, esse conceito de risco, utilizado como medida da probabilidade da ocorrência de casos de dengue, não deve basear-se exclusivamente em índices que indicam a presença do vetor ou incidência da doença, visto que a dinâmica de transmissão da dengue depende da interação entre vetor, agente etiológico, população de hospedeiros suscetíveis num dado ambiente (SUCEN 1997).

No município de Santo André, a área 17, com maior densidade populacional, foi a que apresentou a menor freqüência de casos registrados, enquanto a área 2, que apresenta uma das densidades mais baixas apresentou a maior freqüência. Tipo de moradia, índice de alfabetização e renda familiar também não justificaram essa diferença de freqüência entre os casos registrados no município.

Quanto à evolução temporal e espacial da dengue em Santo André pode ser observada nas figuras 12 a 16, que apresentam as áreas da região urbana do município, e indicam aquelas onde ocorreram casos da doença, no periodo de 1998 a 2002 . Através dessa visão da distribuição espacial da doença foi possível verificar a evolução crescente da doença no município. Importante observar, também, que as primeiras áreas com casos de dengue, nos anos de 1998 e 1999, encontram-se nas regiōes fronteiriças da cidade, fazendo limite com São Paulo, regiões 1 e 4, com São Bernardo do Campo, regiões 10, 11 e 12 e com Mauá, região 2. No ano de 2000, as áreas 21 e 22, que se encontram no limite com a região de proteção de mananciais do município, apresentaram casos de dengue. Em 2001 e em 2002, verificou-se uma ampla distribuição dos casos de dengue, de tal forma que ao final de $2002 \mathrm{em}$ todas as áreas do município registraram-se casos da doença.

Mesmo com uma baixa incidência, hoje, todas as áreas da cidade de Santo André registraram casos de dengue. Isto coloca em discussão o fato da doença se tornar autóctone na cidade de Santo André. Sabe-se que o Aedes aegypti também é encontrado no município, portanto, existe o risco da transmissão epidêmica ter seu início. 
Em Santo André, assim como em São Paulo, a partir da ocorrência do primeiro caso, em novembro de 1998, a incidência de casos importados de dengue foi crescente no município. Considerando que o vírus da dengue altera seu potencial epidêmico quando circula entre as populações, as epidemias podem ser explosivas ou podem delinear picos epidêmicos, dependendo para essas distintas apresentaçōes da interação de fatores locais (TEIXEIRA 1999). Esses fatores, que envolvem aspectos climáticos, econômicos, demográficos, ambientais, políticos e sociais devem ser utilizados no planejamento e nas campanhas de combate a essa doença. 


\section{8 - Infestação do Aedes aegypti}

A infestação do Aedes aegypti no município de Santo André tem seu início no ano de 1996, quando do encontro de dois focos, localizados em pontos estratégicos, um na área 1 e outro na área 4 da cidade, locais de monitoramento realizado pela SUCEN. A partir de 1998, até o final de 1999,0 Departamento de Vigilância à Saúde de Santo André (DVS-SA), sob convênio do Programa de Erradicação do Aedes aegypti no estado de São Paulo (PEAa), realizou as atividades de vigilância entomológica. Com o término do trabalho dos funcionários contratados por meio do convênio do PEAa, em dezembro de 1999, e necessitando adequar-se ao Plano Plurianual de Investimento (PPI), foi assinado um convênio entre o Departamento de Vigilância à Saúde de Santo André e a Organização Não Governamental Instituto Acqua (Ação, Cidadania, Qualidade Urbana e Ambiental). Por meio desse convênio, o DVS-SA realizou treinamento e capacitação de agentes, responsáveis pelo trabalho de campo no que diz respeito ao controle do vetor. Esses agentes foram selecionados pelo Instituto Aqcua e contratados por meio de recursos financeiros repassados pela Prefeitura de Santo André que, por sua vez, os recebia do Ministério da Saúde. A assinatura desse convênio foi registrada em 22 de junho de 2000. A partir desse momento, foi feito o treinamento dos agentes e, portanto, o ano de 2000 foi muito prejudicado com relação à pesquisa larvária. Em 2001, no entanto, as equipes organizadas iniciaram um trabalho sistemático e planejado de controle do mosquito na cidade. Essa explicação torna-se necessária porque o ano de 2000 representou um hiato no trabalho realizado pelo municipio. Dessa forma, comparações e associações somente poderão ser feitas de maneira mais significativa a partir do ano de 2001. 


\section{9 - Infestação do Aedes aegypti e os fatores ecológicos}

Em 1998, foram detectados dois focos do mosquito, ambos em pontos estratégicos da área 1. Em 1999 o número de focos foi de 23, sendo 9 deles na área 1. Nesse mesmo ano, observou-se, pela primeira vez no município, a presença de focos nos domicilios nas áreas 2 e 5 . Em 2000, foram encontrados 6 focos, dois deles em domicílios nas áreas 1 e 2. Como já comentado anteriormente, essa diminuição do número de focos representou falta de atividade de vigilância no municipio. Em 2001, foram 120 focos, sendo 39 em domicílios. Em 2002, dos 158 focos encontrados, 49 foram no domicílio e em 2003, até o mês de julho, registraram-se 192 focos em domicílios, dos 285 focos no município. Esses registros confirmam a tendência à endofilia desse mosquito. Mesmo considerando que a pesquisa larvária tenha sido realizada de forma mais sistemática pelo municipio a partir de 2001, pode-se verificar um aumento da detecção de focos do Aedes aegypti.

A partir dos registros dos trabalhos de campo, realizados pelas equipes de agentes do Setor de Controle de Zoonoses do DVS-SA, e de registros da SUCEN foi calculado o Indice de Infestação Predial mensal para os anos de 2001, 2002 e 2003, até o final de julho. Esse índice apresentou uma distribuição sazonal, pois verificou-se que os maiores valores do corresponderam aos primeiros meses do ano (Fig 17 ). 


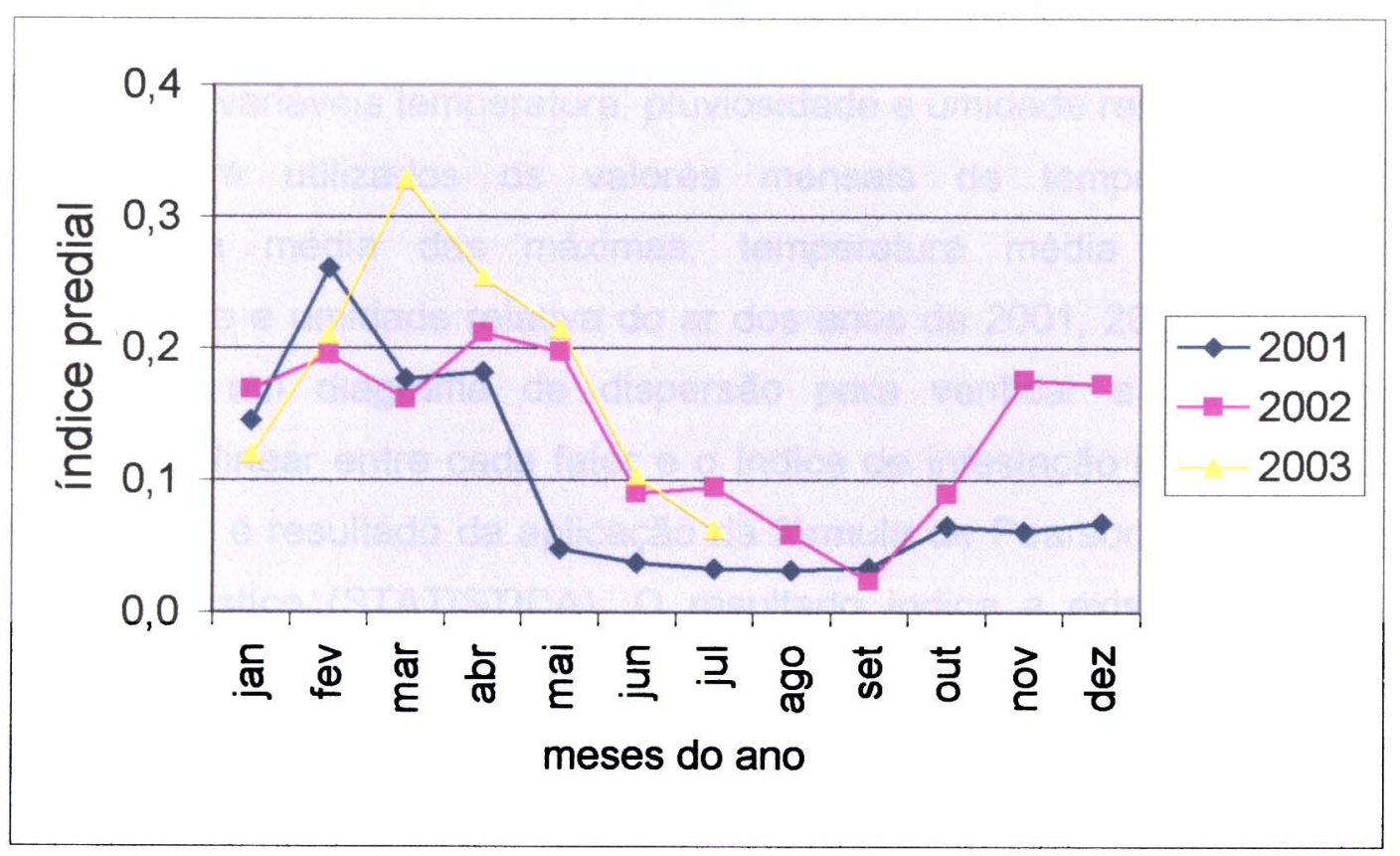

Fonte: Departamento de Vigilância à Saúde - Santo André - SUCEN

Figura 17 - Índice mensal de infestação predial em Santo André, de 2001 a 2003 (dados até julho).

Observou-se que, além do índice ser maior no início do ano, nos três anos observados, este foi aumentando a cada ano, o que mostra que a dispersão do mosquito foi se ampliando no município durante o período estudado.

Originário da região afrotropical, o Aedes aegypti é encontrado nas regiöes tropicais e subtropicais, distribuindo-se entre os paralelos $45^{\circ} \mathrm{N}$ e $40^{\circ} \mathrm{S}$ (FORATTINI 2002). Portanto, o estabelecimento dessa espécie em qualquer território deve estar relacionada a fatores ecológicos, como por exemplo a temperatura, que é dependente desse padrão latitudinal de distribuição do mosquito. A disponibilidade de locais que possam armazenar água de chuva, em ambientes urbanos, aumenta nesses locais a quantidade de recipientes onde as fêmeas desse mosquito podem realizar a postura de 
ovos. Portanto, o ambiente apresenta fatores que devem influenciar na densidade de população do Aedes aegypti. Como esses fatores ecológicos variam de forma sazonal, assim como variou o índice de infestação predial observado no município, realizou-se um teste de correlação entre esse indice e as variáveis temperatura, pluviosidade e umidade relativa do ar.

Foram utilizados os valores mensais de temperatura média, temperatura média das máximas, temperatura média das mínimas, pluviosidade e umidade relativa do ar dos anos de 2001, 2002 e 2003. Foi construído um diagrama de dispersão para verificar a existência de correlação linear entre cada fator $e$ o índice de infestação predial. $O$ valor obtido $(r$ ), é resultado da aplicação da fórmula de Pearson e submetido a teste estatístico (STATISTICA). O resultado indica a existência de uma correlação fraca, média ou forte entre as variáveis estudadas. Os resultados obtidos na aplicação desse teste encontram-se na tabela 6 .

Tabela 6 - Coeficiente de correlação ( $r$ ) entre Índice de Infestação Predial e Temperatura Média, Temperatura Média das Máximas, Temperatura Média das Mínimas, Precipitação e Umidade Relativa do Ar, entre 2001 e 2003 (até julho), no município de Santo André.

\begin{tabular}{llll}
\hline & 2001 & 2002 & 2003 \\
\hline Temp. Máxima & 0,810 & 0,423 & 0,397 \\
Temp. Média & 0,859 & 0,708 & 0,496 \\
Temp. Mínima & 0,819 & 0,691 & 0,457 \\
Umidade & 0,042 & 0,568 & 0,441 \\
Precipitação & 0,365 & 0,470 & 0,104 \\
\hline
\end{tabular}

Fonte: DVA SA - CETESB - EMPLASA

Observou-se uma forte correlação entre o índice de infestação predial e a temperatura média mensal nos anos de 2001 e 2002. Quanto às variáveis umidade relativa do ar e precipitação, verificou-se uma fraca correlação com o índice de infestação predial nesses anos. Os resultados para o ano de 2003 mostram uma fraca correlação entre essas variáveis e o 
indice de infestação predial, possivelmente devido ao fato de terem sido utilizados valores somente até o mês de julho.

CONSOLI e OLIVEIRA, 1998, destacaram a importância das chuvas sobre a densidade populacional do mosquito, embora esse vetor possa manter uma população considerável durante as estações menos chuvosas em virtude dos hábitos da população em manter alguns criadouros como vasos, cisternas, tambores. COSTA, 1996, e COSTA e NATAL, 1998, observaram relação diretamente proporcional entre o índice de infestação (IB) e a pluviosidade, já que, nesse estudo, a maior freqüência de recipientes positivos localizou-se no peridomicílio, podendo, portanto, serem preenchidos com água da chuva. Esses exemplos mostram que os resultados de precipitação em Santo André e sua correlação com o índice de infestação predial devem ser considerados junto com a realidade local, pois os hábitos da população podem interferir na densidade populacional do mosquito. $O$ fato da correlação entre a precipitação e o índice de infestação obtida para esse município ser fraca, pode indicar a presença de recipientes que armazenam água independentemente da precipitação. Portanto, as ações de vigilância do município devem levar em consideração essa característica regional.

Em outras localidades brasileiras também foram pesquisadas a existência de associação entre fatores ecológicos e índices de infestação do mosquito. Assim, REBELO e col., 1999, estudando a distribuição do Aedes aegypti no Maranhão destacaram que a temperatura, constante quase $o$ ano todo, parece não exercer influência na abundância mensal desse mosquito, enquanto que a pluviosidade parece ser o fator limitante. Já, SANTOS, 2003, em Maceió, encontrou correlação positiva entre chuva e temperatura e o índice de infestação do Aedes aegypti. Por sua vez, GLASSER e GOMES, 1997 e 2000, destacaram a influência da temperatura e da pluviosidade na expansão do Aedes aegypti no estado de São Paulo. TEIXEIRA, 1999, destaca a redução da densidade da população de vetores em função da queda de temperatura e umidade.Esses resultados são concordantes com 
os da pesquisa em Santo André, no que diz respeito à associação da temperatura com os índices de infestação.

Com relação à umidade relativa do ar, embora VEZZANI, 2001, considere um fator importante para a dispersão do mosquito adulto, essa variável apresentou uma correlação baixa com a infestação em Santo André.

No caso da pluviosidade, em Santo André, observou-se uma correlação positiva baixa com o índice de infestação. É sabido que um aumento da pluviosidade aumenta a disponibilidade de criadouros, pois recipientes encontrados no peri-domicílio podem acumular água. No entanto, recipientes encontrados no domicílio podem independer de regime pluviométrico, como é o caso dos vasos de plantas, por exemplo, o que demonstra que a ação antrópica ultrapassa, algumas vezes, a ação de fatores ambientais. Isso quer dizer que mesmo na estação mais seca pode ocorrer uma maior disponibilidade de recipientes. Além disso, outros fatores podem estar agindo juntamente com os fatores estudados como, por exemplo, a exposição de recipientes utilizados como criadouros ao sol. Nesse sentido, BARRERA e col., 2000, e TUN LIN e col., 1995, verificaram que recipientes mantidos em locais sombreados apresentam um potencial maior de serem utilizados como criadouros pelo Aedes aegypti.

Assim, o estudo dessas variáveis deve ser ampliado para poder estabelecer uma associação mais ampla com a infestação do mosquito no ambiente urbano.

A influência de fatores climáticos não pode ser tratada totalmente desvinculada da organização da vida humana. Dessa maneira, mesmo considerando esses parâmetros, é fundamental buscar no comportamento da comunidade explicações complementares à ação de fatores abióticos na infestação do mosquito vetor da dengue. 


\subsection{0 - Distribuição Espacial do Aedes aegypti}

O estudo da distribuição do mosquito vetor da dengue é importante sob o ponto de vista epidemiológico pois pode fornecer informações sobre a infestação na região estudada e contribuir com ações de controle nesse local.

Observando-se o avanço da ocupação territorial do Aedes aegypti em Santo André, figuras 18 a 22, verificou-se que a área 1 , que faz divisa com a cidade de São Paulo, e que apresenta uma grande quantidade de oficinas de desmanche e de auto-peças, correspondeu ao local de entrada do mosquito no município, detectado pela primeira vez em 1996 e posteriormente em 1998. Em 1999, os focos são encontrados nas áreas $1 \mathrm{e}$ 5, divisa com São Paulo, área 2, divisa com Mauá e 11, divisa com São Caetano do Sul. Esses focos foram encontrados em pontos estratégicos e armadilhas larvitrampas, porém, nas áreas 2 e 5, foram encontrados focos no domicílio, apresentando vaso e tambor como criadouros (Fig.18). No ano de 2000 , os focos foram encontrados nas áreas 1,5 e 2, novamente na região periférica da cidade em atividades realizadas em pontos estratégicos e armadilhas, porém, nas áreas 1 e 2, os focos foram encontrados no domicílio, sendo o vaso o recipiente utilizado como criadouro (Fig.19). Em 2001, observaram-se focos nas regiões periféricas já citadas nos anos anteriores, mas observou-se também um avanço do mosquito da região norte para o sul da cidade e, novamente, foram encontrados recipientes positivos no domicílio nas áreas $1,2,3,4,6,8,11,12,13,15$ e 18 (Fig.20). No ano de 2002, focos nos domicilios são encontrados nas áreas $1,4,6,8$, 10, 11, 12,15 e 21 (Fig.21). No ano de 2003, focos nos domicílios são encontrados nas áreas $2,4,5,6,7,8,10,11,12,13,15,16,18$ e 20 (Fig.22). 


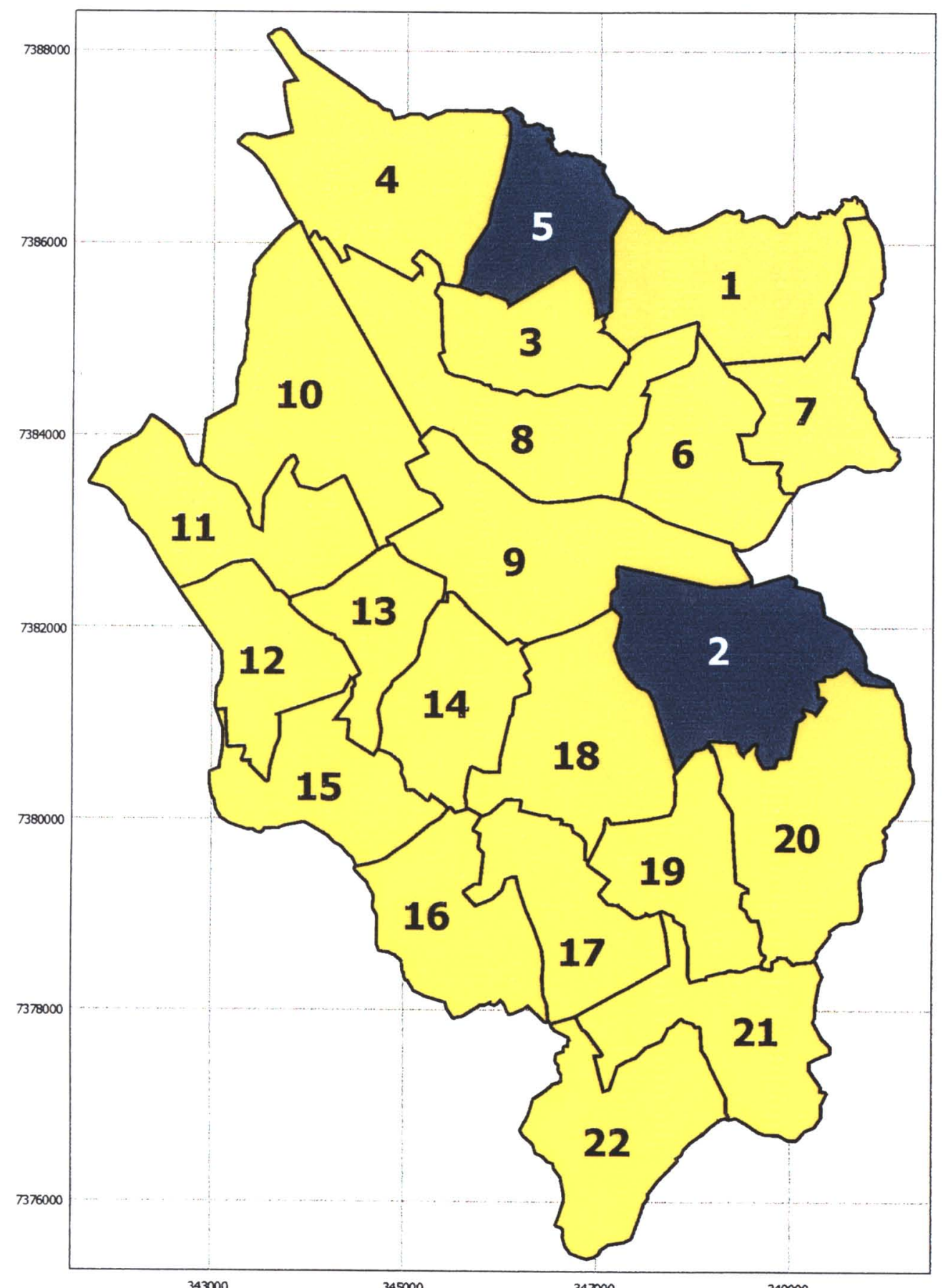

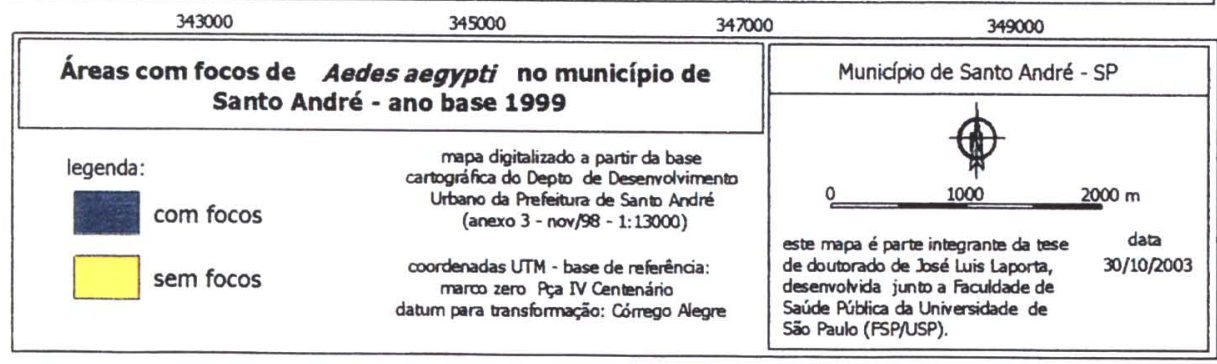

Figura 17 - Áreas com focos de Aedes aegypti em domicílio no município de Santo André - ano base 1999 


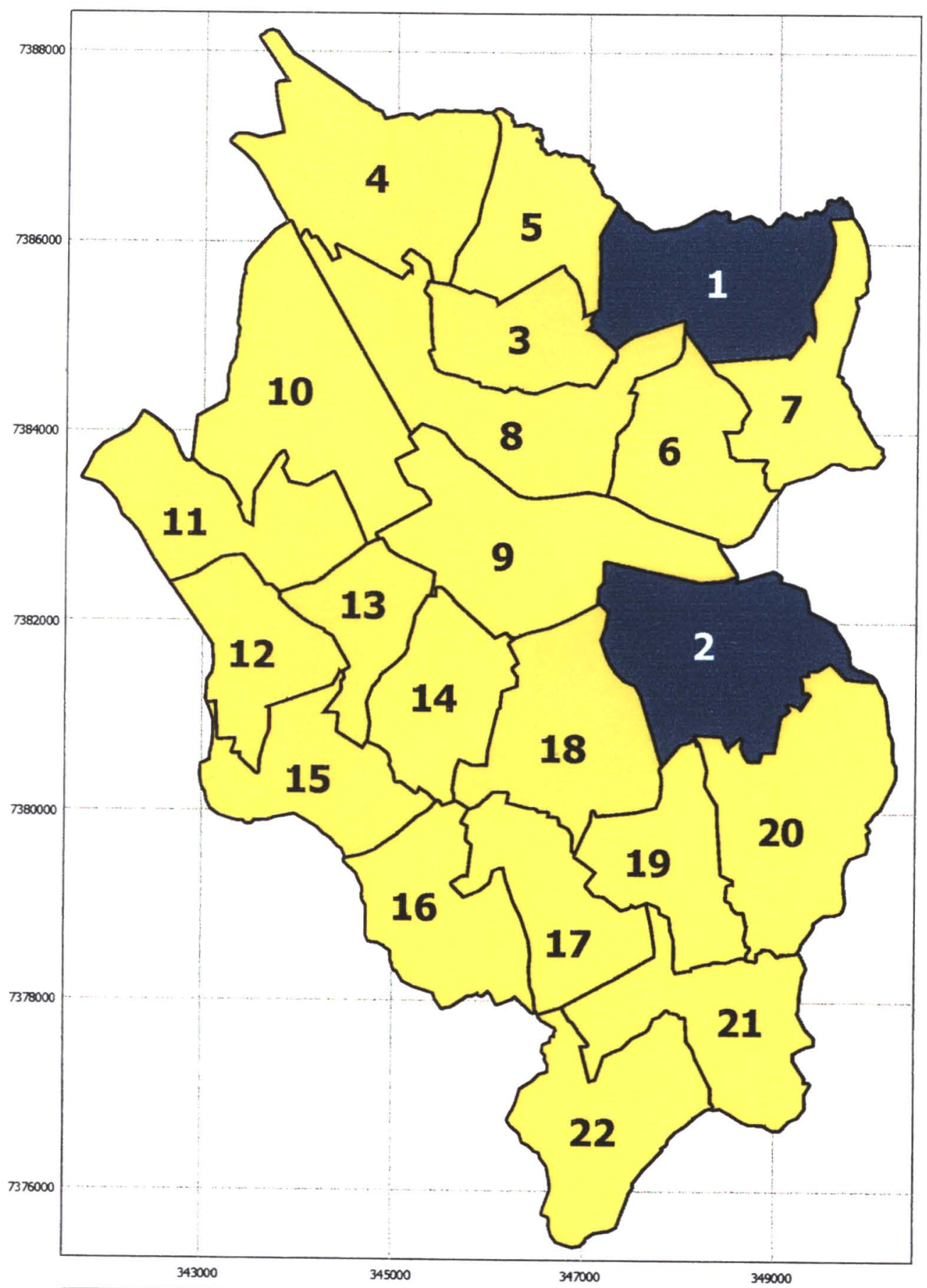

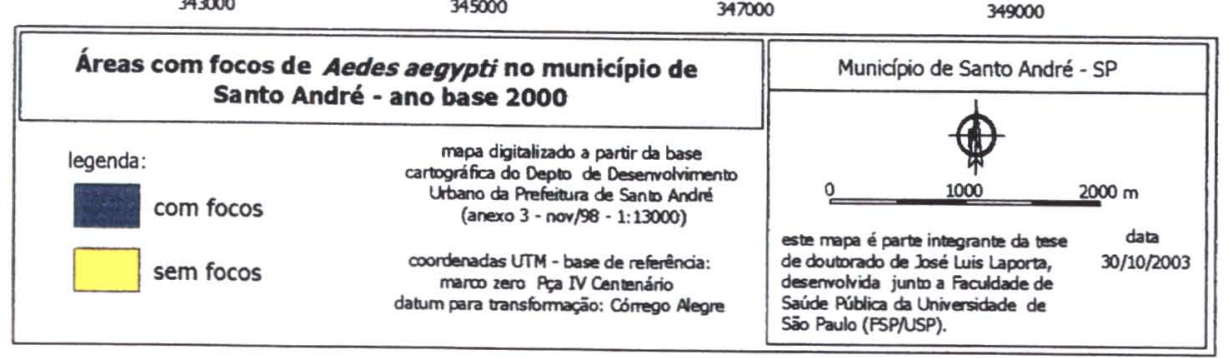

Figura 18 - Áreas com focos de Aedes aegypti em domicílio no município de Santo André - ano base 2000 


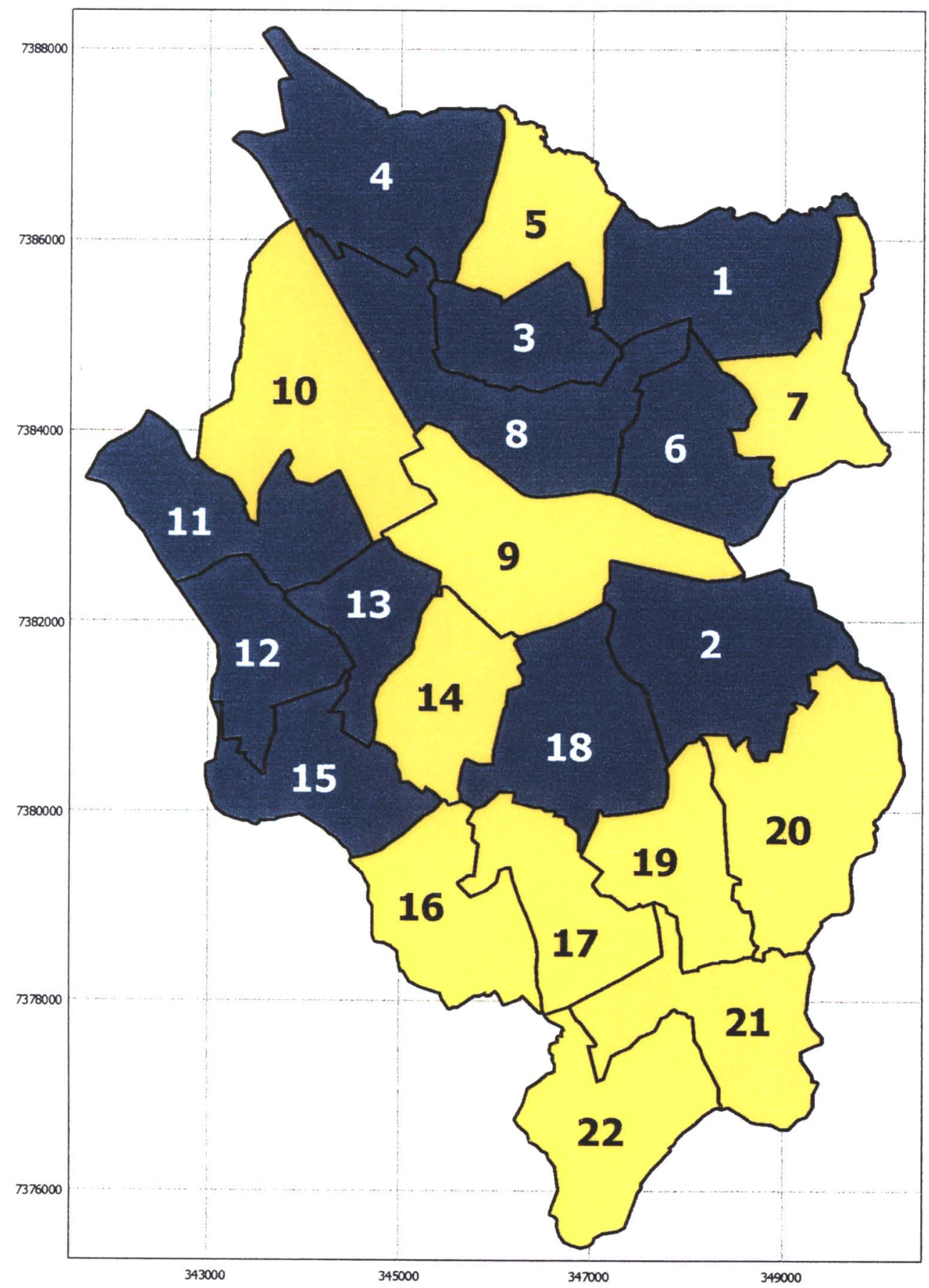

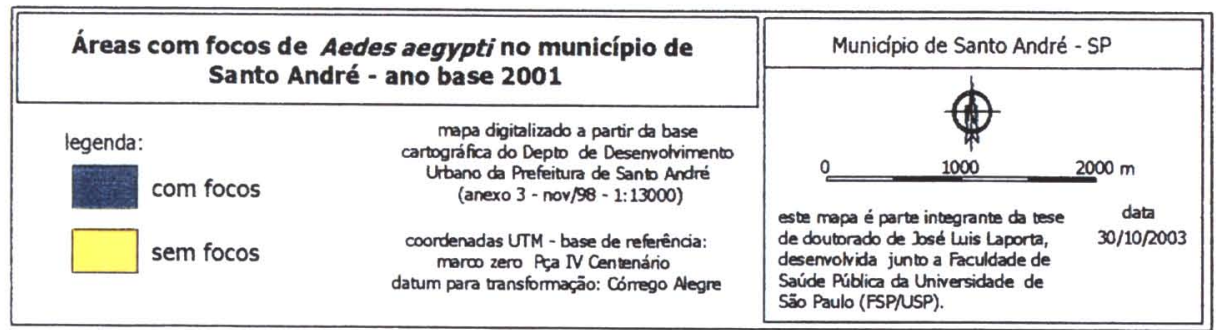

Figura 19 - Áreas com focos de Aedes aegypti em domicílio no município de Santo André - ano base 2001 


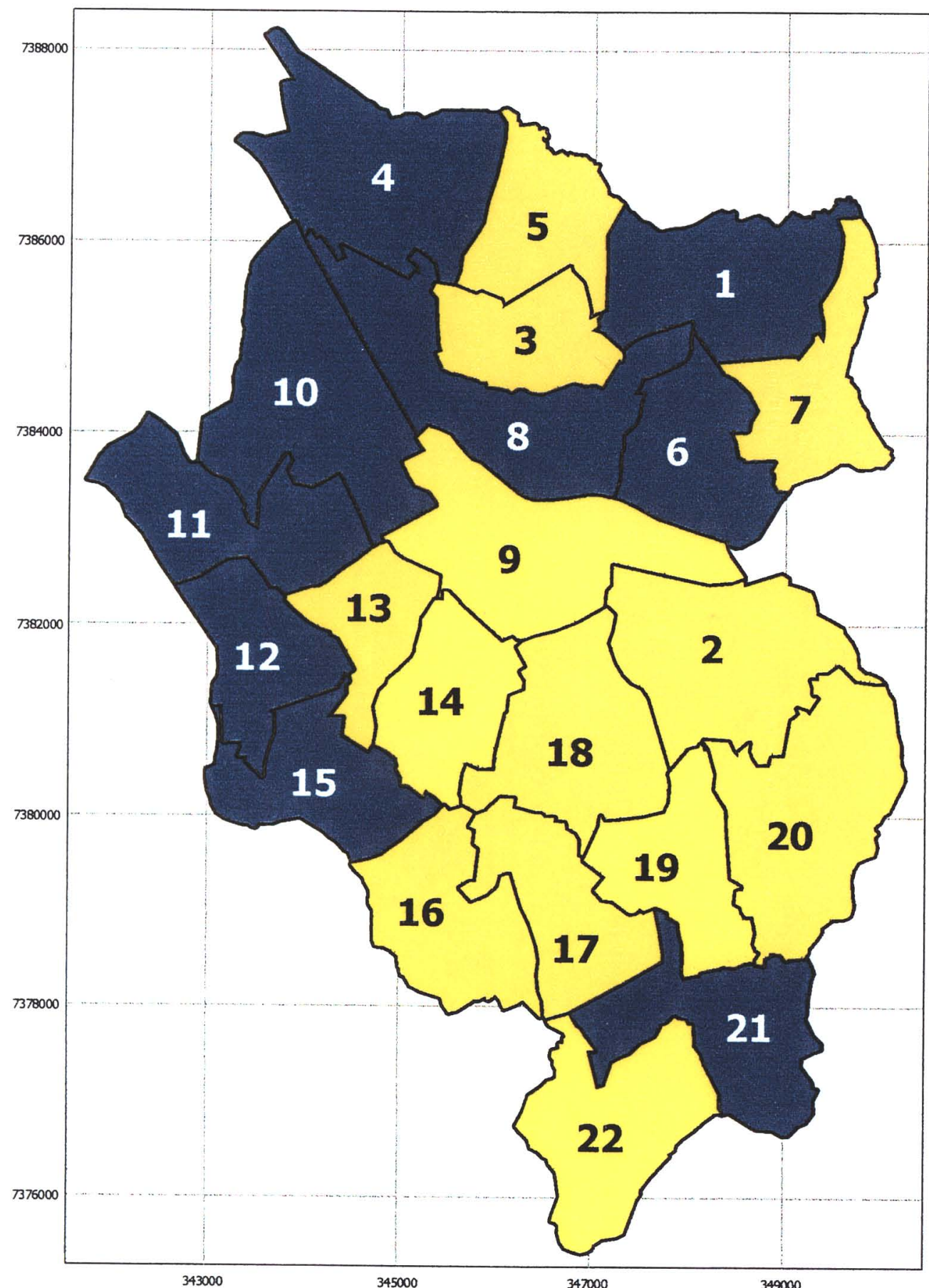

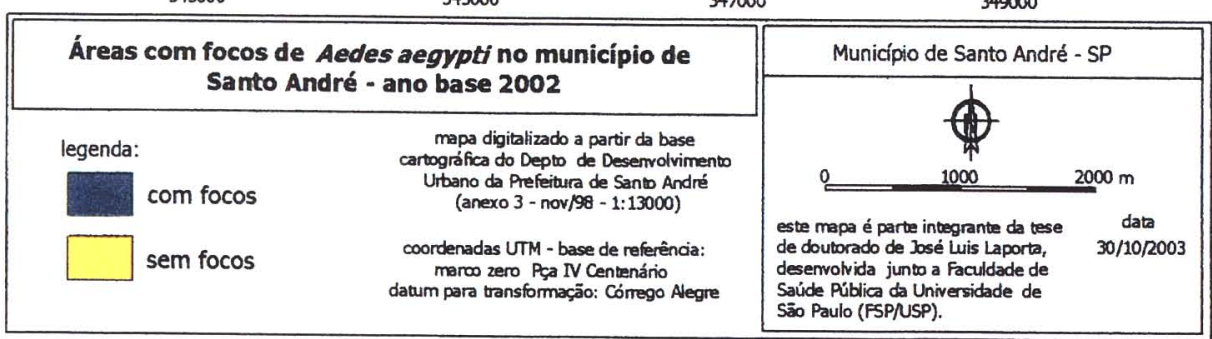

Figura 20 - Áreas com focos de Aedes aegypti em domicílio no município de Santo André - ano base 2002 


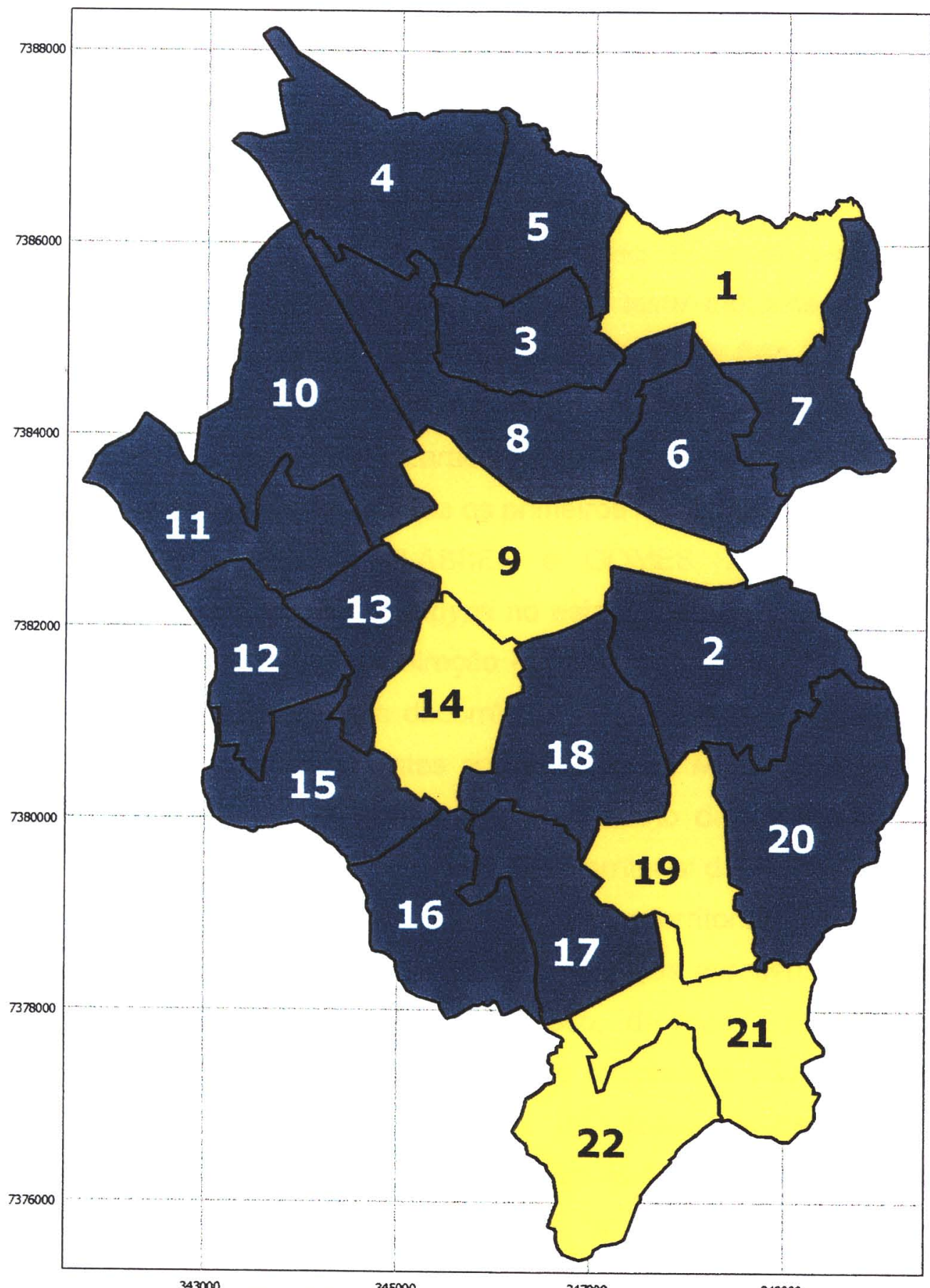

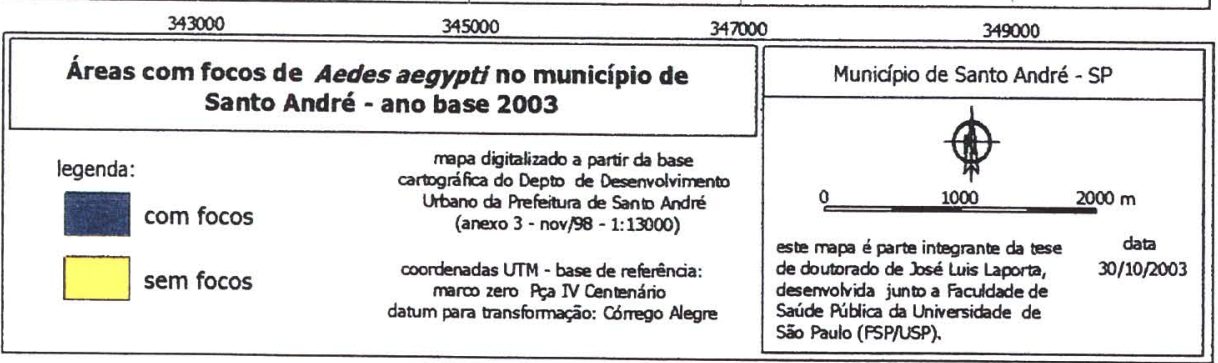

Figura 21 - Áreas com focos de Aedes aegypti em domicílio no município de Santo André - até julho 2003 
A cada ano pesquisado, observou-se que as larvas do mosquito, encontradas inicialmente em pontos estratégicos, passaram a ser encontradas também em recipientes do peridomicílio e do domicilio, como vasos, tambores, latas e caixa d'água.

Pode-se notar que, espacialmente, o mosquito deslocou-se, na região urbana de Santo André, no sentido norte-sul e leste-sudoeste. A entrada do vetor na cidade ocorreu na fronteira com a cidade de São Paulo, em uma área com uma grande quantidade de comércio de desmanches, de autopeças e de ferro-velho, locais caracterizados como pontos estratégicos do município, onde foram encontrados os primeiros focos

GLASSER, 1997 e GLASSER e GOMES, 2000, estudando a expansão territorial do Aedes aegypti no estado de São Paulo, concluíram que ela se deu segundo uma direção geográfica, ou seja, da região oeste para leste, provavelmente em decorrência da presença dessa espécie em municípios vizinhos, pertencentes aos estados de Mato Grosso do Sul e Paraná, e afirmaram que temperatura e tamanho da população humana foram fatores que influenciaram a expansão territorial do mosquito.

Essas observações relativas à expansão territorial desse mosquito, reforçam a importância de as regiões fronteiriças apresentarem-se como porta de entrada de vetores. Além disso, deve-se considerar que a infestação depende da disponibilidade de recipientes viáveis que podem servir como criadouros. A presença de depósitos de ferro velho, desmanches e auto-peças na área 1 do município, provavelmente, ofereceu as condições necessárias para o início da dispersão do mosquito no município de Santo André. Essa área faz divisa com bairros da zona leste da cidade de São Paulo, local de grande densidade populacional (200 a 400 habitantes/hectare), segundo o censo do IBGE, 2000, e um corredor de transporte urbano, unindo os bairros dessa região de São Paulo aos municípios do $A B C$.

Mesmo considerando que a fêmea do Aedes aegypti, de um modo geral, não alcança grandes distâncias, a área 1, fronteiriça de São Paulo e 
sabidamente com presença de focos àquela época, apresentava-se de forma paisagística urbana continuada e sem barreiras geográficas em relação ao município paulistano, facilitando, portanto, a dispersão do mosquito.

Embora tenha sido observada dispersão de até 800 metros da fêmea do mosquito, essa dispersão parece estar relacionada à disponibilidade de criadouros (FORATTINI 2002). Dessa forma, além do hábito que a população tem de acumular receptáculos que podem ter valor comercial, os depósitos, como os de ferro-velho, armazenam recipientes que, quando sem proteção, podem acumular água e aumentar a disponibilidade de criadouros para o mosquito.

Quanto à distribuição espacial dos focos do mosquito, em relação às áreas e ao local de encontro de criadouros, ou seja, pontos estratégicos, armadilhas e domicílios, verificou-se que, das 22 áreas do município, foram registrados focos do mosquito em 21 áreas, sendo 11 com pontos estratégicos, 20 com armadilhas e 18 áreas com focos no domicílio. Assim, as ações de vigilância do município podem ter mapeadas as áreas mais críticas com relação à presença do vetor (Tab. 7e Fig. 23). 
Tabela 7 - Distribuição de focos por domicílio segundo a área de registro em Santo André, de 1998 a 2003.

\begin{tabular}{ccc}
\hline Área & \multicolumn{3}{c}{ Domicílio } \\
\hline 1 & Focos & $\%$ \\
\hline 2 & 4 & 2,6 \\
3 & 6 & 1,7 \\
4 & 55 & 2,6 \\
5 & 9 & 24,2 \\
6 & 25 & 3,9 \\
7 & 4 & 10,9 \\
8 & 12 & 1,7 \\
9 & 0 & 5,2 \\
10 & 14 & 0,0 \\
11 & 58 & 6,1 \\
12 & 20 & 25,5 \\
13 & 3 & 8,7 \\
14 & 0 & 1,3 \\
15 & 4 & 0,0 \\
16 & 3 & 1,7 \\
17 & 1 & 1,3 \\
18 & 2 & 0,4 \\
19 & 0 & 0,9 \\
20 & 1 & 0,0 \\
21 & 2 & 0,4 \\
Total & 229 & 100,0 \\
\hline
\end{tabular}

Fonte: Departamento de Vigilância à Saúde - Santo André 


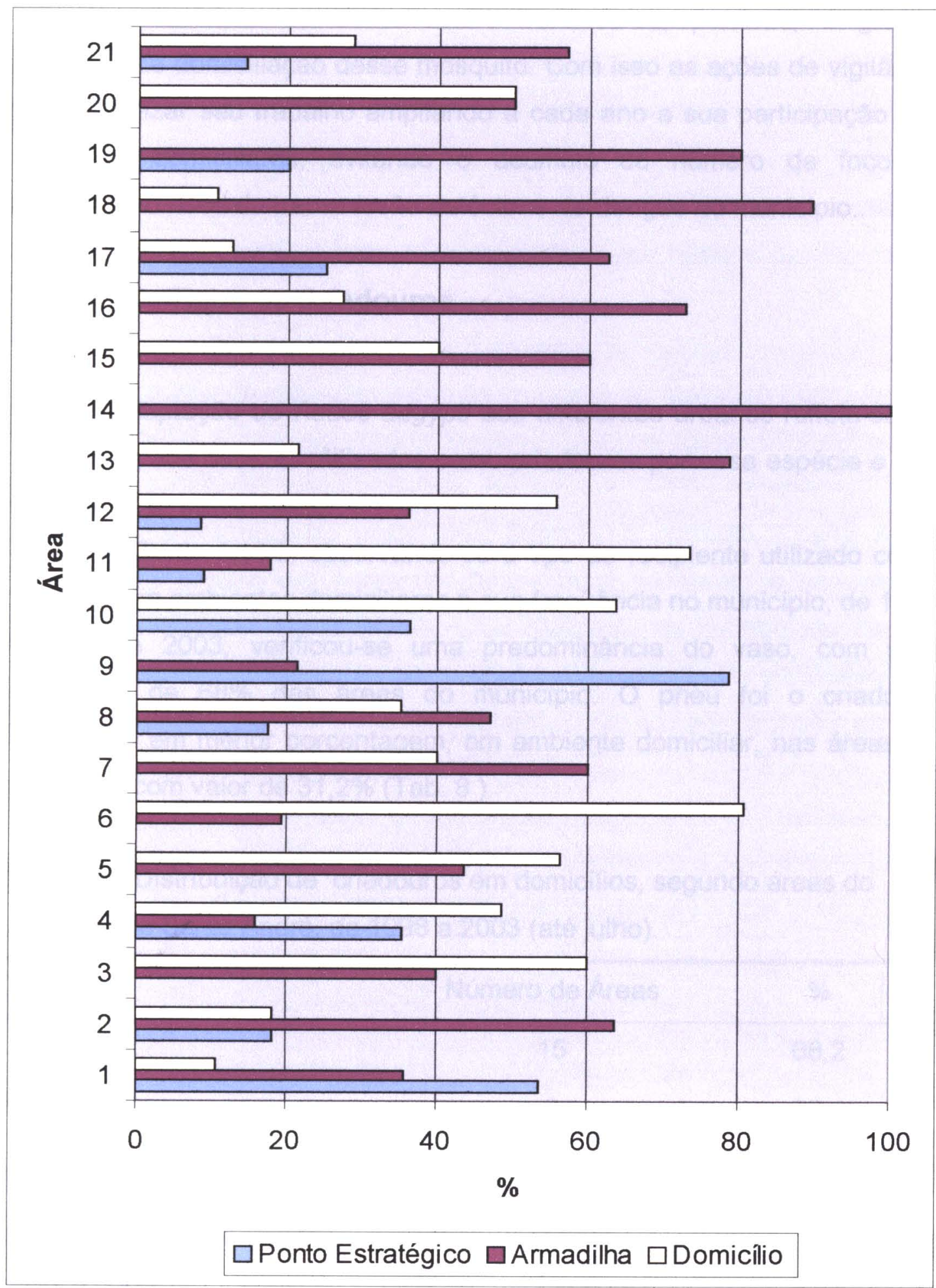

Fonte: Departamento de Vigilância à Saúde - Santo André

Figura 23 - Distribuição de focos por área, segundo o local de registro em Santo André, de 1998 a 2003 (até julho). 
No município de Santo André verificou-se, portanto, a grande tendência de domiciliação desse mosquito. Com isso as ações de vigilância devem realizar seu trabalho ampliando a cada ano a sua participação nos ambientes domiciliares, evitando o acúmulo do número de focos e diminuindo o risco da transmissão autóctone de dengue no município..

\subsection{1 - Tipos de Criadouros}

A adaptação do Aedes aegypti aos ambientes urbanos reflete-se na preferência aos hábitats utilizados como criadouros por essa espécie e que influenciam a transmissão.

Em Santo André, observando-se o tipo de recipiente utilizado como criadouro em ambientes domiciliares e sua freqüência no município, de 1998 a julho de 2003, verificou-se uma predominância do vaso, com uma freqüência de $68 \%$ das áreas do município. O pneu foi o criadouro encontrado em menor porcentagem, em ambiente domiciliar, nas áreas do município, com valor de $31,2 \%$ (Tab. 8 ).

Tabela 8 - Distribuição de criadouros em domicílios, segundo áreas do município de Santo André, de 1998 a 2003 (até julho).

\begin{tabular}{lcc}
\hline Criadouro & Número de Áreas & $\%$ \\
\hline Vaso & 15 & 68,2 \\
Tambor & 8 & 36,4 \\
Lata & 11 & 50,0 \\
Pneu & 7 & 31,2 \\
Caixa d'água & 11 & 50,0 \\
Material Removivel & 8 & 36,4 \\
\hline
\end{tabular}

Fonte: Departamento de Vigilância à Saúde - Santo André 
Com relação à distribuição dos tipos de recipientes utilizados como criadouros: vaso, tambor, lata, pneu, material removível e caixa d'água apresentaram participação heterogênea. No entanto, verificou-se que as áreas $4,6,10,11$ e 12 registraram a ocorrência de todos esses recipientes, - que mostra que a presença do mosquito no domicílio demonstra a importância da disponibilidade de criadouros e dos hábitos da população (Tab 9).

A observação sobre o tipo de criadouro do mosquito Aedes aegypti mostrou uma grande variação desde os primeiros achados em Santo André. No ano de 1998, foram registrados os primeiros focos, sendo $50 \%$ em pneus e $50 \%$ em material não-removivel. No ano de 1999, registrou-se pela primeira vez a presença do mosquito no domicilio e, portanto, a partir desse momento, os recipientes presentes nesse local passaram a representar potenciais criadouros do mosquito. Uma descrição da distribuição desses criadouros em cada ano confirmou a grande capacidade de domiciliação e mostrou também que recipientes mantidos pelo homem em seu próprio ambiente podem se tornar criadouros do vetor.

Assim, um estudo sobre a distribuição temporal do tipo de recipiente encontrado no domicilio pode demonstrar não somente a sinantropia desse mosquito, mas também os hábitos da população com relação à disponibilização de criadouros. 
Tabela 9 - Áreas de Santo André segundo a ausência (N) ou presença (S) dos tipos de criadouros em domicílios, de 1998 a 2003 (até julho).

\begin{tabular}{|c|c|c|c|c|c|c|}
\hline Área & Vaso & Tambor & Lata & Pneu & $\begin{array}{l}\text { Caixa } \\
\text { d'água }\end{array}$ & $\begin{array}{c}\text { Material } \\
\text { Removivel }\end{array}$ \\
\hline 1 & $S$ & $S$ & $S$ & $N$ & $N$ & $N$ \\
\hline 2 & $S$ & $N$ & $N$ & $N$ & $N$ & $N$ \\
\hline 3 & $S$ & $S$ & $N$ & $S$ & $N$ & $S$ \\
\hline 4 & $S$ & $S$ & $S$ & $S$ & $S$ & $S$ \\
\hline 5 & $S$ & $N$ & $S$ & $N$ & $S$ & $S$ \\
\hline 6 & $S$ & $S$ & $S$ & $S$ & $S$ & $S$ \\
\hline 7 & $S$ & $N$ & $N$ & $N$ & $S$ & $N$ \\
\hline 8 & $S$ & $N$ & $S$ & $N$ & $S$ & $N$ \\
\hline 9 & $N$ & $\mathrm{~N}$ & $N$ & $\mathrm{~N}$ & $N$ & $N$ \\
\hline 10 & $S$ & $S$ & $S$ & $S$ & $S$ & $S$ \\
\hline 11 & $S$ & $S$ & $S$ & $S$ & $S$ & $S$ \\
\hline 12 & $S$ & $S$ & $S$ & $S$ & $S$ & $S$ \\
\hline 13 & $S$ & $S$ & $S$ & $N$ & $N$ & $N$ \\
\hline 14 & $N$ & $N$ & $N$ & $N$ & $\mathbf{N}$ & $N$ \\
\hline 15 & $S$ & $N$ & $S$ & $N$ & $\mathbf{N}$ & $\mathrm{N}$ \\
\hline 16 & $N$ & $N$ & $N$ & $S$ & $S$ & $N$ \\
\hline 17 & $N$ & $N$ & $N$ & $N$ & $N$ & $S$ \\
\hline 18 & $S$ & $N$ & $N$ & $N$ & $S$ & $N$ \\
\hline 19 & $N$ & $N$ & $N$ & $N$ & $\mathrm{~N}$ & $N$ \\
\hline 20 & $N$ & $N$ & $N$ & $N$ & $\mathrm{~S}$ & $N$ \\
\hline 21 & $S$ & $N$ & $S$ & $N$ & $N$ & $N$ \\
\hline 22 & $\mathrm{~N}$ & $\mathrm{~N}$ & $\mathrm{~N}$ & $\mathrm{~N}$ & $\mathrm{~N}$ & $N$ \\
\hline
\end{tabular}


No ano de 1999, vaso e tambor foram os únicos criadouros positivos encontrados em domicílios da cidade de Santo André (Fig. 24 ).

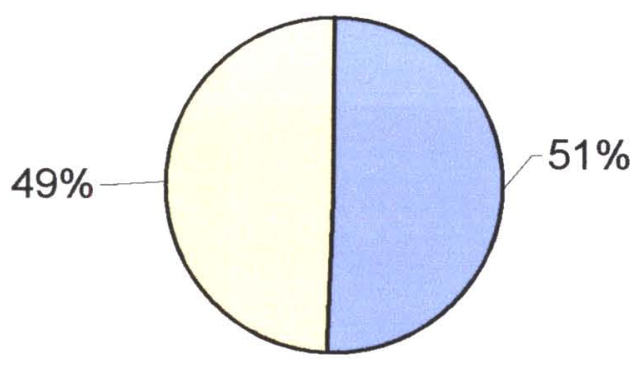

Fonte: Departamento de Vigilância à Saúde - Santo André

Figura 24 - Distribuição do tipo de recipiente utilizado como criadouro pelo Aedes aegypti no município de Santo André em 1999.

No ano de 2000, o vaso representou o único recipiente utilizado como criadouro, em domicílios, na cidade de Santo André.

Os recipientes utilizados como criadouros nos domicílios, em 2001, foram vaso, pneu, tambor, lata, caixa d'água e material removível. 0 destaque importante é que o vaso representou o principal recipiente e, além dos demais recipientes encontrados, deve-se destacar a participação da caixa d'água como um dos criadouros domiciliares (Fig. 25 ). 


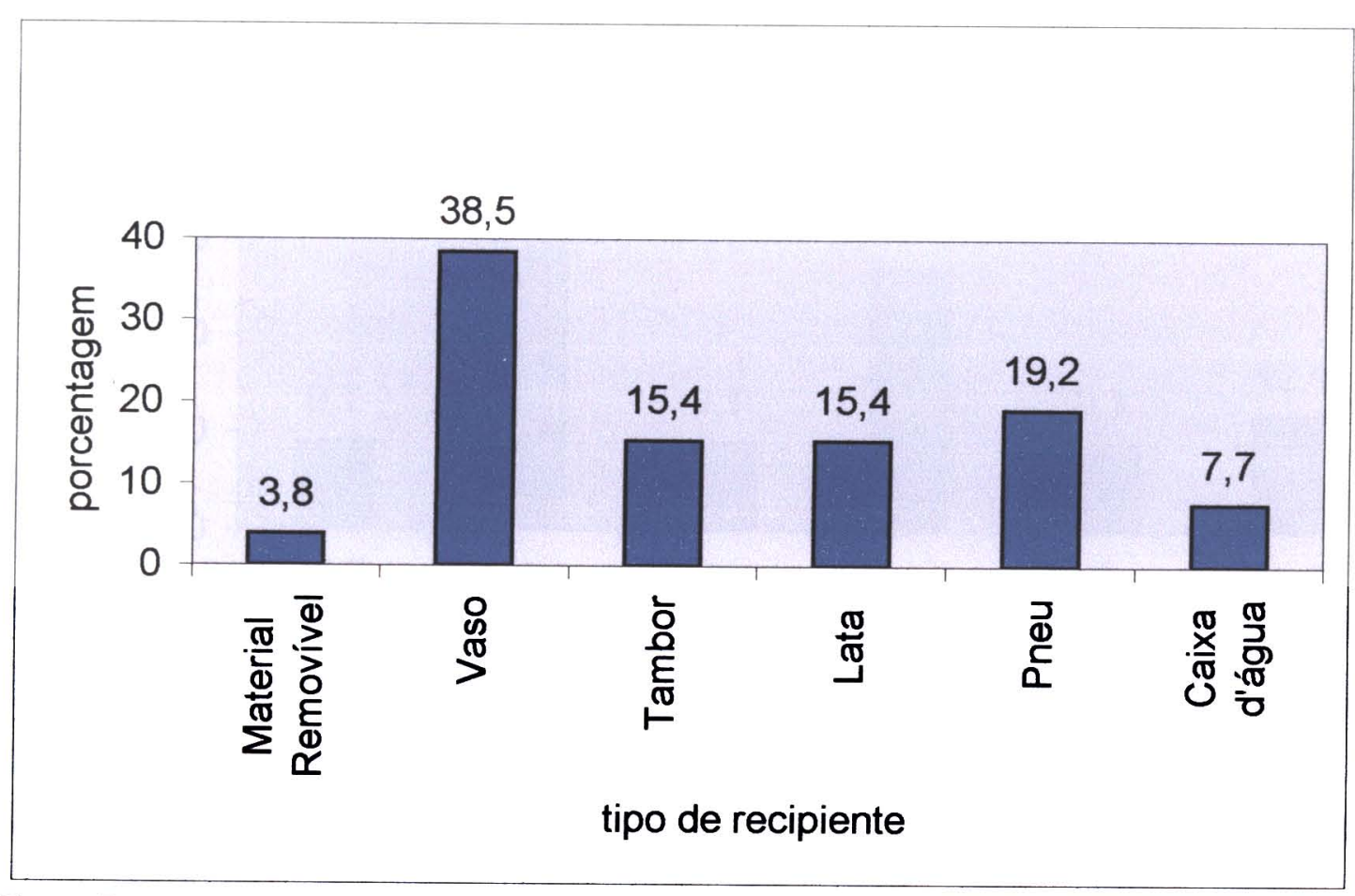

Fonte: Departamento de Vigilância à Saúde - Santo André

Figura 25 - Distribuição do tipo de recipiente utilizado como criadouro no domicílio pelo Aedes aegypti no município de Santo André em 2001.

No ano de 2002, observou-se um aumento da ocorrência de caixa d'água como criadouro. Lata e material removível têm sua ocorrência aumentada, porém o vaso continua como o principal recipiente utilizado como criadouro em domicilios (Fig 26). 


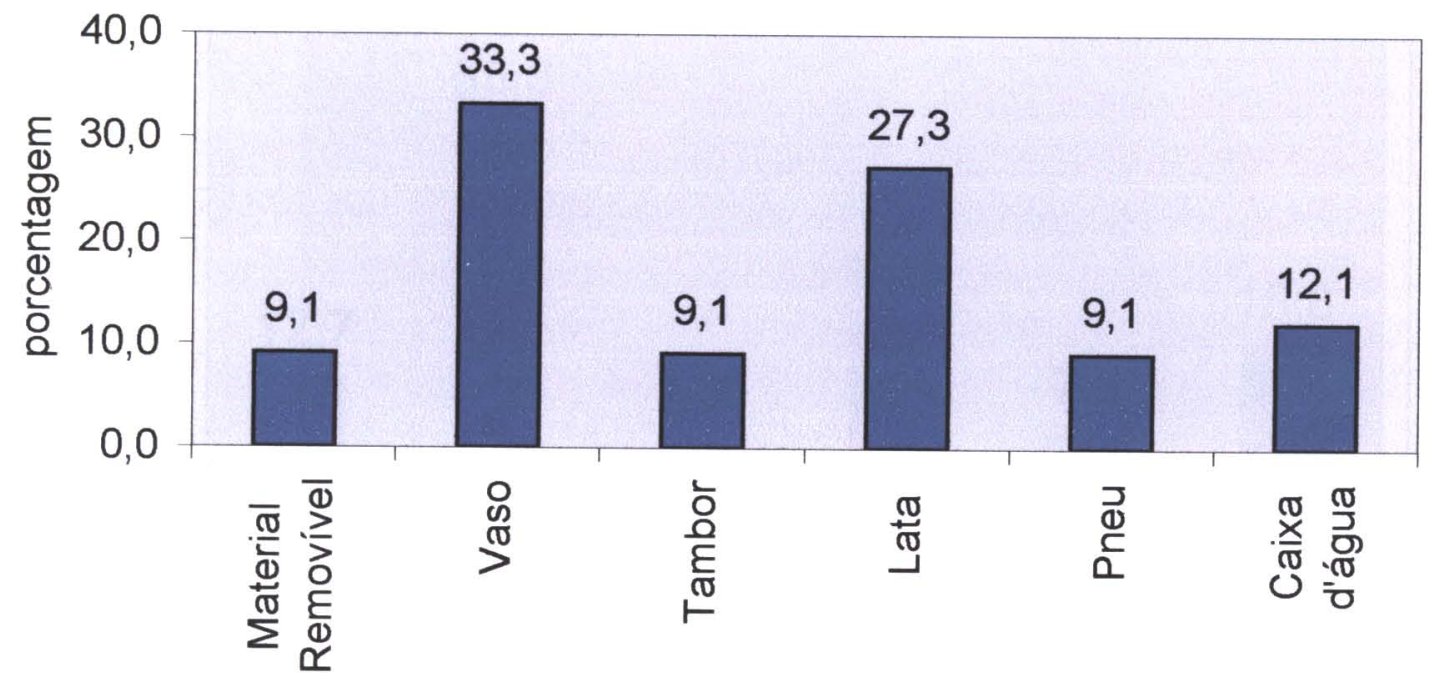

tipo de recipiente

Fonte: Departamento de Vigilância à Saúde - Santo André

Figura 26 - Distribuição do tipo de recipiente utilizado como criadouro no domicílio pelo Aedes aegypti no município de Santo André em 2002.

No ano de 2003 , até o mês de julho, observou-se aumento percentual da ocorrência de caixa d'água como criadouro. Material removível também tem sua ocorrência aumentada, o que significa aumento de materiais descartáveis no domicilio. No entanto, o vaso continua sendo o principal recipiente utilizado como criadouro em domicílios em Santo André, também no ano de 2003 (Fig 27). 


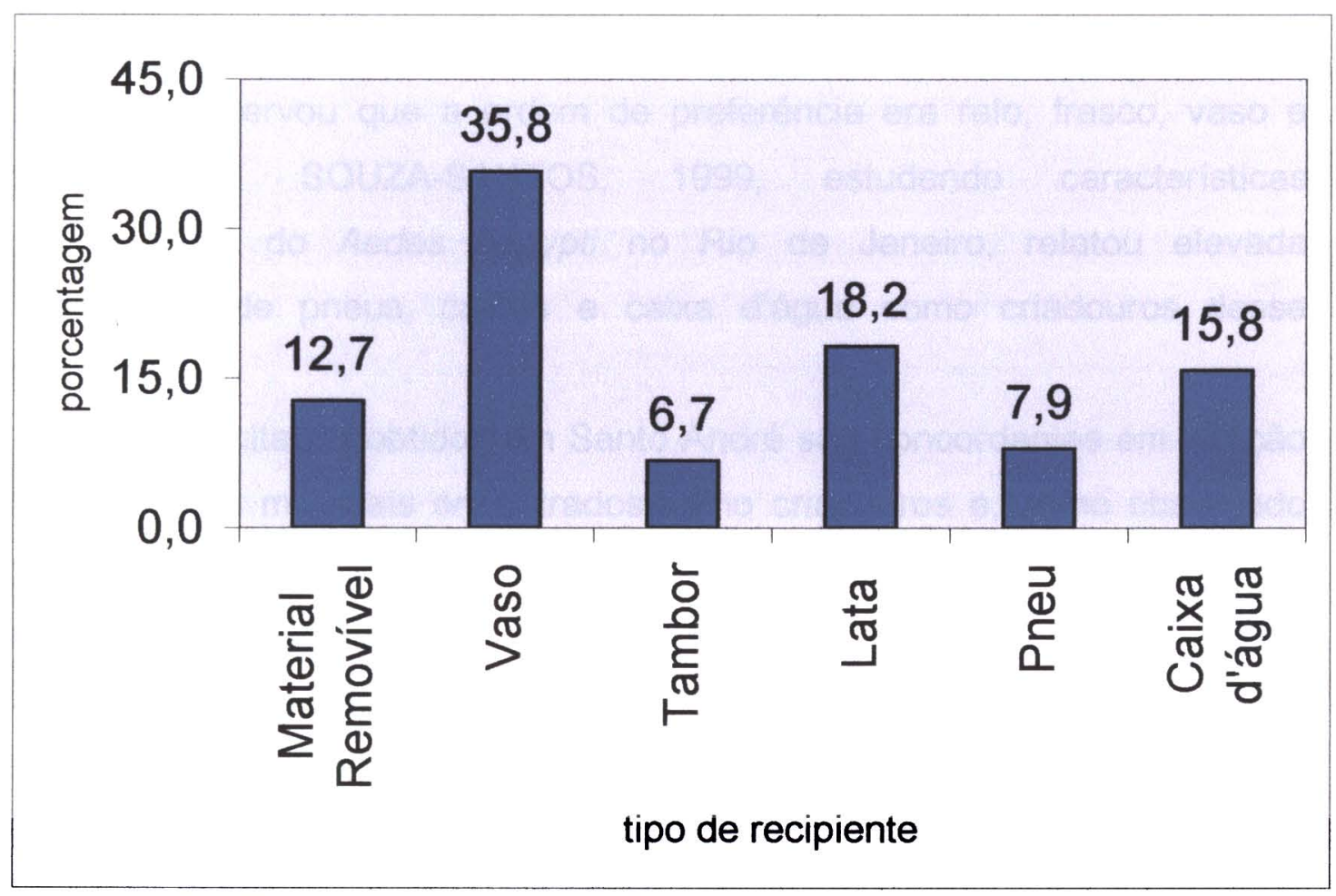

Fonte: Departamento de Vigilância à Saúde - Santo André

Figura 27 - Distribuição do tipo de recipiente utilizado como criadouro no domicílio pelo Aedes aegypti no município de Santo André em 2003.

Com relação ao tipo de criadouro encontrado no município, verificouse que, inicialmente, esses recipientes eram encontrados somente em pontos estratégicos e, a partir de 1999, focos do mosquito foram encontrados pela primeira vez em domicílio. A partir desse momento o mosquito passa a ser encontrado em outros recipientes.

CHIARAVALLOTTI-NETO, 1992, em estudo realizado em São José do Rio Preto destacou a importância do vaso como criadouro do Aedes aegypti. COSTA, 1996, e COSTA e NATAL, 1998, destacaram a importância do recipiente vaso, não somente nos períodos chuvosos, como também nos períodos de estiagem. Por sua vez, PEREIRA, 1996, entre novembro de 1993 e dezembro de 1994, descreve peças e materiais, pneus, frascos, vasos, locais de armazenamento fixo, garrafas e bebedouros, nessa ordem, 
como os recipientes de preferência do Aedes aegypti em Araçatuba. Já, MELO, 1997, descreve, em Ribeirão Preto, a preferência pelo vaso como principal criadouro no período de 1989 a 1994. PEREIRA, 2001, estudando os principais criadouros na cidade de Santos, entre novembro de 1999 abril de 2000 , observou que a ordem de preferência era ralo, frasco, vaso e peça/material. SOUZA-SANTOS, 1999, estudando características bioecológicas do Aedes aegypti no Rio de Janeiro, relatou elevada positividade de pneus, calhas e caixa d'água como criadouros desse mosquito.

Os resultados obtidos em Santo André são concordantes em relação aos principais materiais encontrados como criadouros e, como observado pelos autores citados, o vaso tem um papel importante como recipiente propício ao desenvolvimento de larvas do mosquito. No entanto, os hábitos de uma espécie são variáveis e as observações indicam preferência por alguns tipos de criadouros, de acordo com cada região (FORATTINI 1965).

Em Santo André, os recipientes pesquisados e descritos como principais criadouros foram vaso, pneu, lata, tambor, caixa d'água e material removivel. A utilização desses recipientes como criadouros foi sendo modificado ano após ano, o que mostra uma característica do mosquito no que diz respeito a sua domiciliação. Nesse contexto, GOMES, 1986, descreve domiciliação como fenômeno biológico juntamente com fatores intrínsecos das populações e extrínsecos do ambiente, nos quais incluem-se as influências antrópicas. A ocorrência de criadouros de Aedes aegypti ocorre, principalmente, nos ambientes urbanos e na dependência dos hábitos da população local. Isso significa que fatores ligados à educação e à cultura da população desempenham um importante papel na infestação por esses mosquitos (FORATTINI 2002).

Dessa forma, acompanhar a participação de cada tipo de criadouro representa um estudo da adaptação desse mosquito ao ambiente urbano, mas, também, um estudo da participação da população, pois é ela que contribui para o acúmulo do material que ficará exposto e servirá de criadouro para os mosquitos. Nesse sentido, MOORE, 1978, descreveu que 
96\% dos criadouros encontrados em Porto Rico foram feitos pelo homem. Por sua vez, GUBLER, 1989, relata a explosão do número de recipientes artificiais que se tornaram habitats ideais para as larvas de Aedes aegypti. IBANEZ-BERNAL e GOMEZ-DANTEZ, 1995, consideram que variações no comportamento da população de Aedes aegypti podem estar relacionadas à qualidade de vida da população humana e seus hábitos culturais. Um reforço para registrar a importância do ambiente urbano na dispersão do mosquito foi descrito por LIMA, 1988, que, ao se referir aos percentuais de ocupação dos recipientes do Rio de Janeiro, descreveu o vaso como principal criadouro em residências muito boas e, nos morros, recipientes utilizados para o armazenamento de água foram os principais responsáveis por focos de Aedes aegypti. Assim, considerando-se a importância da participação humana e das condições em que ela vive, podemos encontrar em uma mesma cidade duas realidades diferentes.

Em Santo André, o recipiente mais utilizado como criadouro foi o vaso, em todos os anos, desde o primeiro encontro do mosquito no domicílio. Isso mostra que, mais importante do que deixar recipientes expostos ao ambiente e que poderão acumular água, a população deve ser alertada a respeito do hábito de cultivar plantas, de tal forma que esse procedimento deve ser levado em consideração em qualquer campanha de controle do vetor da dengue. Importância, também, deve ser dada ao papel que a caixa d'água representa no município, pois se trata de municipio servido pela rede de água. Diferentemente de outros locais, a caixa d'água não representa recipiente de acúmulo de água, do tipo cisterna. Essas geralmente ficam descobertas, pois podem acumular, mais facilmente, água da chuva ou mesmo serem preenchidas através de caminhões pipa ou de baldes. Em Santo André, as aglomerações do tipo favela, em área urbana, encontram-se urbanizadas. Portanto, a caixa d'água tornou-se criadouro no município devido ao fato de ficar exposta sobre as construções, principalmente naquelas em que são realizadas obras de ampliações, reformas ou adaptações. A importância epidemiológica desse recipiente foi destacada por FORATTINI, 2003, que observou a presença de larvas em 
caixas d'água localizadas sobre a laje das casas em edificações precárias, e em residências com arquitetura moderna em condomínios de luxo. A vigilância entomológica deve, portanto, reservar um cuidado especial para esses reservatórios. Outro recipiente que foi encontrado em todos os anos em ambiente peridomiciliar foi o pneu. Embora considerado importante em pontos estratégicos, esse recipiente também foi encontrado como criadouro em todos os anos no ambiente domiciliar. Isso demonstra a necessidade de intensificar campanhas para evitar acúmulo desse tipo de material que, de acordo com HONÓRIO, 2001, pode oferecer diferentes condiçōes para a colonização desses mosquitos, de acordo com o volume d'água e a exposição ao sol.

\subsection{2 - Positividade e Distribuição de Larvas por Criadouro}

Com relação ao número médio de larvas encontradas por criadouro no município de Santo André, entre 1998 e 2003, verificou-se que, estatisticamente, não houve diferença entre o número médio de larvas para diferentes recipientes utilizados como criadouro, com intervalo de confiança de $95 \%$. (Tab.10). 
Tabela 10 - Número médio de larvas de Aedes aegypti por criadouro, segundo o tipo de recipiente positivo em Santo André, de 1998 a 2003.

\begin{tabular}{lccccccc}
\hline Recipientes & Larvas & Média & $\begin{array}{c}\text { Desvio } \\
\text { Padrão }\end{array}$ & $\mathrm{n}$ & Erro & \multicolumn{2}{c}{$\begin{array}{c}\text { Intervalo de } \\
\text { Confiança para } \\
\text { Média (95\%) }\end{array}$} \\
\hline Vaso & 904 & 11,16 & 12,87 & 81 & 1,43 & 8,36 & 13,96 \\
Lata & 599 & 13,93 & 15,39 & 43 & 2,35 & 9,33 & 18,53 \\
Tambor & 223 & 12,39 & 8,71 & 18 & 2,05 & 8,37 & 16,41 \\
Pneu & 256 & 11,64 & 11,67 & 22 & 2,49 & 6,76 & 16,51 \\
Mat. Removível & 390 & 14,44 & 14,57 & 27 & 2,80 & 8,95 & 19,94 \\
caixa d'água & 251 & 7,61 & 9,97 & 33 & 1,74 & 4,20 & 11,01 \\
GERAL & 2623 & 11,71 & 12,89 & 224 & 0,86 & 10,02 & 13,40 \\
\hline
\end{tabular}

A figura 28 representa os tipos de recipientes e os valores referentes à média de larvas entre 1998 e 2003 e respectivo intervalo de confiança. 


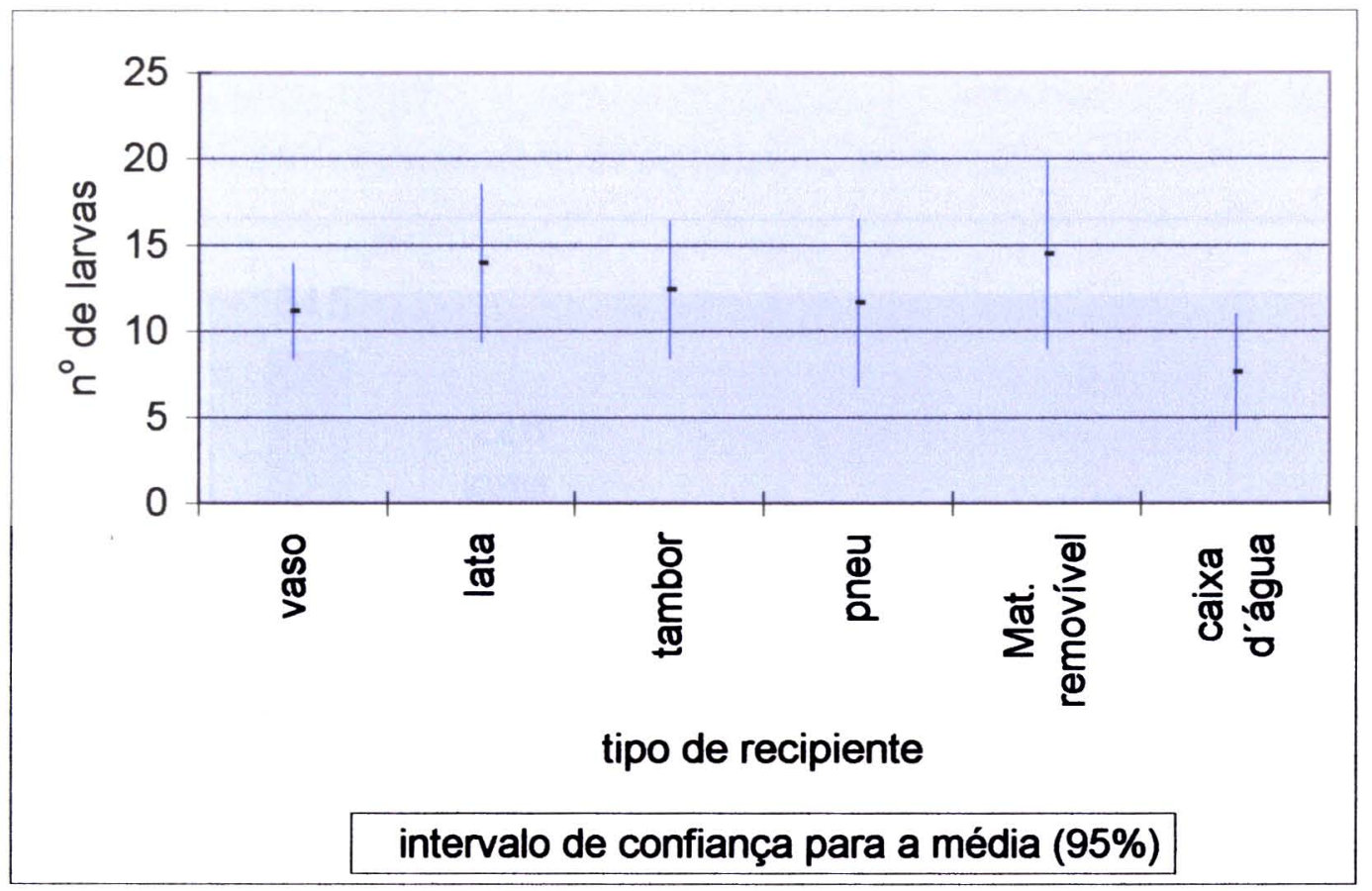

Figura 28 - Média de larvas por recipientes utilizados como criadouros em Santo André e respectivo intervalo de confiança.

Quanto à distribuição dos recipientes nos ambientes domiciliares, ao longo do período estudado, verificou-se que o vaso foi o criadouro que teve maior freqüência, enquanto que tambor foi aquele que apresentou a freqüência menor (Fig. 29 ). 


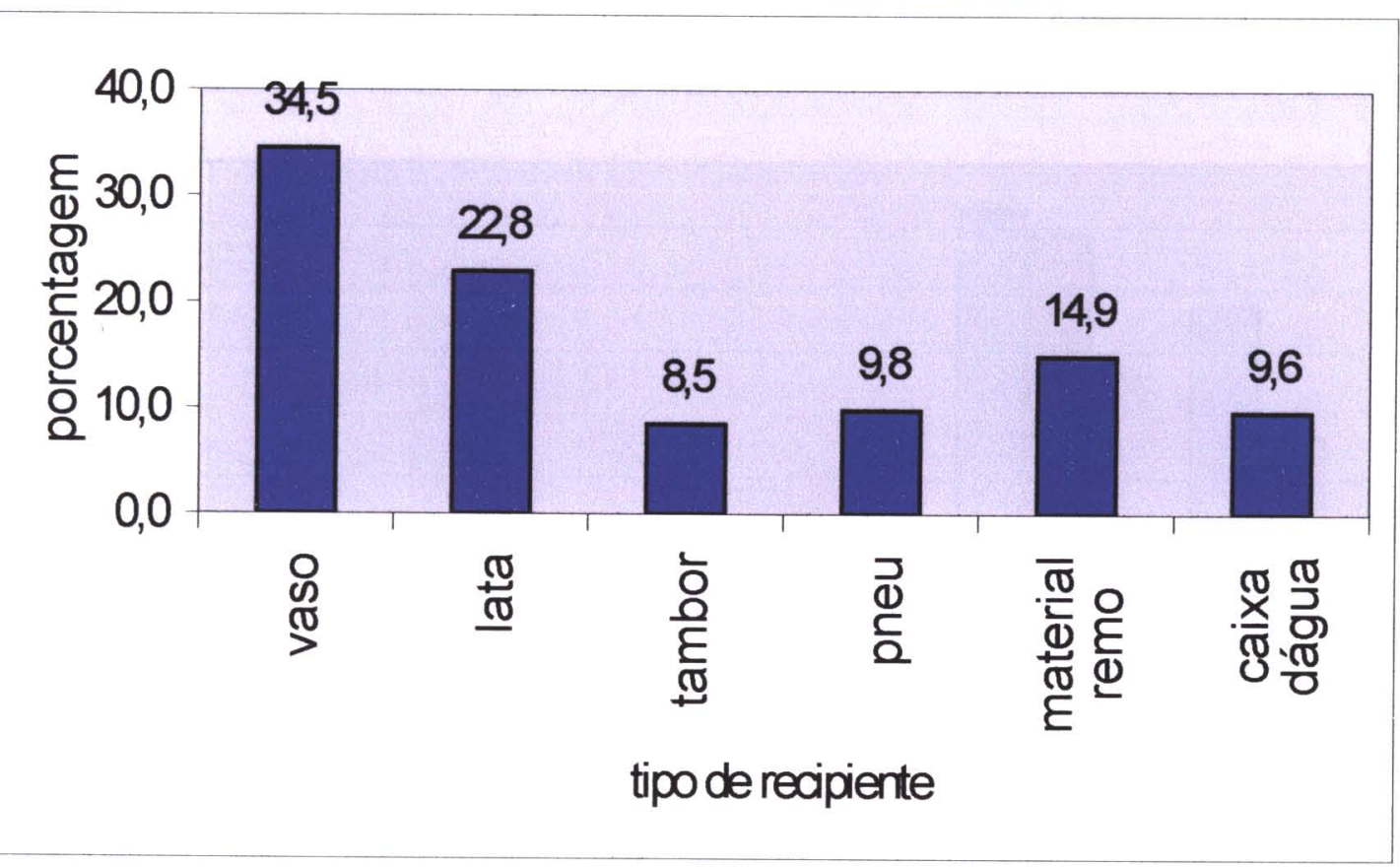

Figura 29 - Distribuição segundo os recipientes utilizados como criadouros em Santo André, de1998 a 2003 (até julho).

Com relação ao tipo de atividade de pesquisa de vigilância desenvolvida pelo município, ou seja, ponto estratégico e armadilha larvitrampa, verificou-se que, excetuando-se 2001, a freqüência de focos positivos nas armadilhas foi maior que o de pontos estratégicos. 0 número de armadilhas larvitrampas no município foi de 400 em 1999, 200 em 2001, 200 em 2002 e 320 em 2003. Em relação ao número de pontos estratégicos no município, foram cadastrados 139 no ano de 1999, 121 em 2000, 126 em 2001, 110 em 2002 e 118 em 2003 (Fig. 31). 


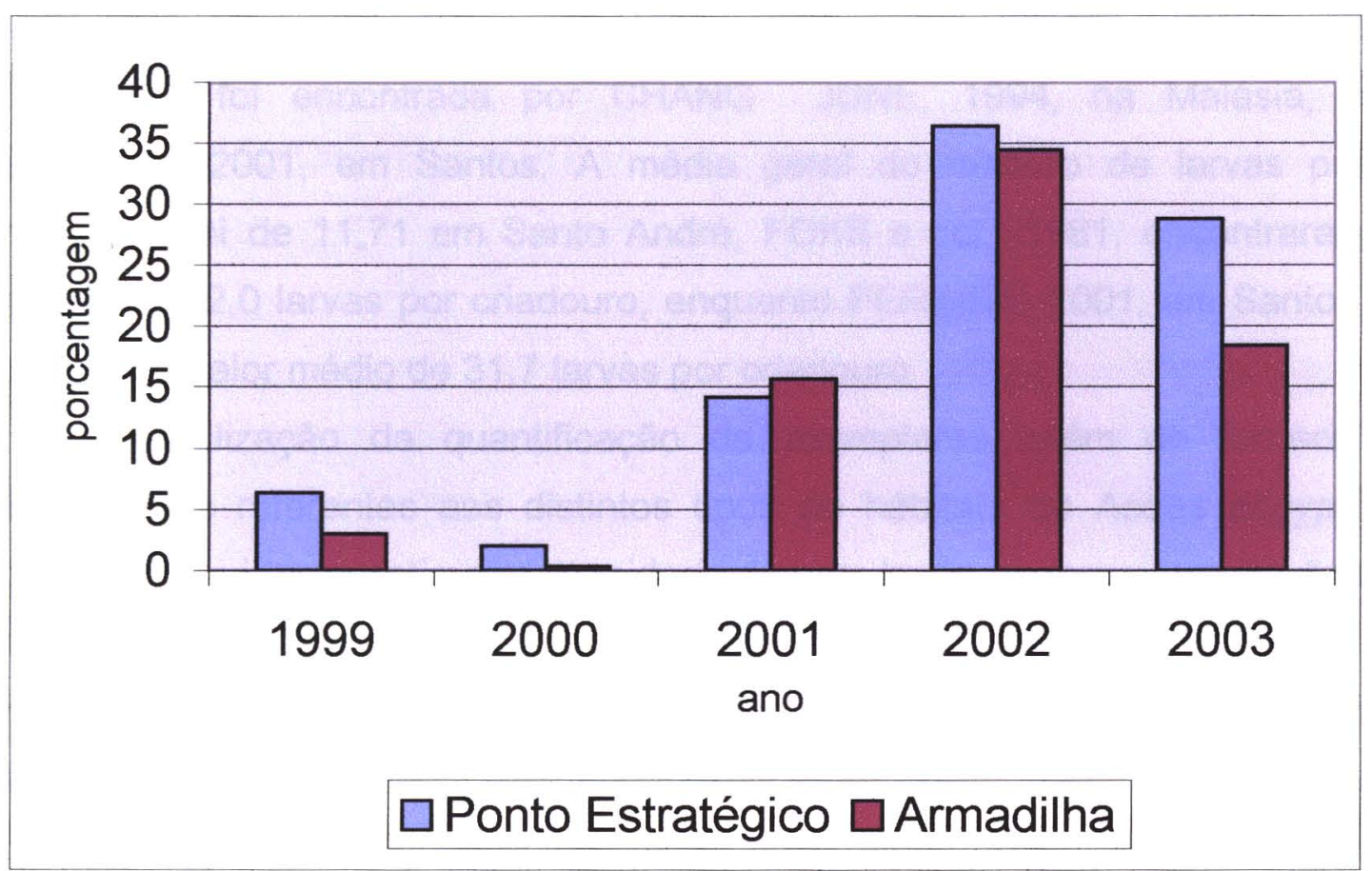

Fonte: Departamento de Vigilância à Saúde - Santo André

Figura 30 - Freqüência de focos positivos registrados em pontos estratégicos e armadilhas em Santo André, de 1998 a 2003 (até julho).

É muito grande nos ambientes urbanos a oferta de recipientes que podem se tornar criadouros de mosquitos. COSTA e NATAL, 1996, relacionam a disponibilidade desses recipientes às condições econômicas, políticas e sociais. Nesse sentido, o peridomicílio apresentou uma participação preponderante na infestação de municipios paulistas (PEREIRA e BARBOSA 1995). Em Santo André, ocorreu o mesmo processo. Após registro em pontos estratégicos, focos do mosquito foram encontrados no domicilio, a partir de 1999, em duas áreas da cidade. Em 2003, somente quatro,das vinte e duas áreas do município, não registraram a presença de focos do Aedes aegypti. 
A realização de estudos que utilizam quantificação de exemplares coletados pode contribuir para as atividades de controle, pois podem, também, estimar a produtividade de criadouros. Em Santo André, o número médio de larvas variou de 7,61 em caixa d'água a 14,44 em material removivel. Variabilidade no número médio de larvas encontradas em criadouros foi encontrada por CHANG JUNE, 1994, na Malásia, e PEREIRA, 2001, em Santos. A média geral do número de larvas por criadouro foi de 11,71 em Santo André. FOKS e col., 1981, encontraram média de 32,0 larvas por criadouro, enquanto PEREIRA, 2001, em Santos, encontrou valor médio de 31,7 larvas por criadouro.

A utilização da quantificação de exemplares, além de fornecer informações referentes aos distintos tipos de hábitats de Aedes aegypti, pode contribuir para estimar a densidade da população de mosquitos adultos e melhor compreender a dinâmica de transmissão da dengue. Portanto, o conhecimento dos níveis de infestação, da distribuição do vetor no município, dos tipos de recipientes utilizados como criadouros é importante para a compreensão local da transmissão. Entretanto, o comportamento da população humana, os fatores climáticos e a prevalência de anticorpos na população também devem ser levados em consideração ao se pensar em açōes de controle.

É evidente que o controle da dengue passa necessariamente pelo controle do vetor. Assim, GRATZ, 1991, discutindo a ocorrência de dengue no Vietnan, Tailândia, Indonésia e Burma afirma que o controle da dengue depende do controle do vetor e isso significa reduzir os habitats das larvas. Por sua vez, GUBLER E CLARK, 1994, dando ênfase ao programa desenvolvido em Porto Rico sugerem um desenvolvimento de programas de controle do Aedes aegypti que sejam efetivos, eficientes e sustentáveis através da utilização da participação da comunidade. Nessa mesma linha, FERNANDEZ e col., 1993, mostraram uma significativa redução no índice de infestação de Aedes aegypti após campanhas de prevenção que incluem a educação. Já, DEGALLIER, 2000, afirma que campanhas envolvendo os meios de comunicação contribuem para o conhecimento sobre dengue e seu 
vetor na população, mas tem pequeno impacto na infestação do mosquito. CHIARAVALLOTTI-NETO, 1997, em pesquisa realizada em residências da área urbana de São José do Rio Preto verificou que os conhecimentos demonstrados pela população analisada foram bastantes satisfatórios, entretanto, essa aquisição de conhecimentos não foi suficiente para a diminuição dos niveis de infestação dos vetores da dengue no município. Por sua vez, MARZOCHI, 1994, sugere a adoção de atividade científica e técnicas interdisciplinares e ampla participação da comunidade na discussão dos aspectos metodológicos a serem empregados na população. As ações de combate ao Aedes aegypti envolvem três componentes básicos: saneamento do meio-ambiente, comunicação e informação e combate direto ao vetor (TEIXEIRA 1999).

É consenso geral, portanto, que qualquer plano para controle da dengue deve necessariamente depender da participação da comunidade. Essa participação, no entanto, não significa que ela deve ser informada ou que ela deve realizar algum procedimento sugerido ou imposto por uma autoridade. Essa participação deve partir de projetos educacionais que apontem para uma mudança comportamental. Para isso é necessário um planejamento visando um retorno em prazo longo. Designar essa tarefa à atuação dos agentes de saúde, mesmo que associada a campanhas gerais ou pontuais, pode resultar em um inicial sucesso, porém, a ausência desses agentes pode pôr o plano em uma situação de risco. As ações governamentais devem buscar formas de participação da comunidade no processo de prevenção, e para isso é necessário implementar metodologias pedagógicas capazes de proporcionar mudanças no comportamento no que diz respeito aos cuidados individuais e coletivos com a saúde, com ênfase na necessidade de redução e eliminação dos criadouros potenciais do mosquito transmissor da dengue (TEIXEIRA 1999).

A área urbana do município de Santo André conta com abastecimento da água tratada e coleta de esgoto, assim como também conta com serviço de coleta de lixo em toda a área urbana. O municipio não apresenta aterro sanitário em sua área urbana, portanto, considerando o 
saneamento do meio-ambiente, a cidade está bem servida. Dessa forma, o trabalho educativo representa uma forma de se esperar obter resultados que possam evitar o aumento da infestação e o número de casos de dengue.

Outro aspecto importante quando se pensa em controle de dengue diz respeito à vigilância epidemiológica e entomológica. GOMES, 2002, conceituou vigilância entomológica como a "contínua observação e avaliação de informações originadas das características biológicas e ecológica dos vetores, nos niveis das interações com hospedeiros humanos e animais reservatórios, sob a influência de fatores ambientais que proporcionem o conhecimento para detecção de qualquer mudança no perfil de transmissão das doenças". Nesse sentido, uma vigilância entomológica a ser feita no municipio deveria eleger um indicador para monitoramento do grau de infestação e avaliar permanentemente as ações realizadas pelo município no que diz respeito ao controle do vetor. Isso implica, também, ampliar o conjunto de informações referentes à ecologia do mosquito e sua interação com os fatores climáticos e as características sócio-econômicas de cada área trabalhada.

Para um trabalho amplo e que propicie resultados eficientes, poderse-ia realizar no município atividades coordenadas de vigilância epidemiológica, vigilância entomológica, monitoramento dos fatores climáticos, dinâmica da infestação vetorial, monitoramento da atividade humana que resulte em risco de contrair a doença e pronta intervenção nos casos positivos. 


\section{5 -RECOMENDAÇÕES}

Atenção especial deve ser dirigida às áreas localizadas nos limites do município, no sentido de alertar a população desses locais quanto à ocorrência dos casos de dengue e de infestação do mosquito. Um trabalho conjunto e integrado com os serviços de vigilância dos municípios da região seria muito importante para manter sempre atualizadas as informações que visam ao controle da doença.

O planejamento de ações de educação, comunicação e informação, deve buscar uma abrangência efetiva dos diferentes setores da comunidade, de forma a possibilitar a participação de todos nas diferentes etapas de elaboração de campanhas de prevenção e controle. As ações devem garantir a participação conjunta na proposição de metodologias capazes de proporcionar mudanças de comportamento da população. Atenção especial deve ser dirigida à discussão ampla dos potenciais criadouros, principalmente aqueles que a própria comunidade acaba disponibilizando ao vetor.

O serviço de vigilância poderia eleger um indicador de infestação e avaliar constantemente as ações de controle do vetor, juntamente com a ocorrência de casos, de tal forma que esses dados possam ser registrados em uma distribuição espacial que oriente o serviço de controle.

Outras pesquisas devem ser feitas no município que possam levar a uma melhor compreensão do fato de a região não apresentar casos autóctones, embora existam casos importados e infestação do vetor.

Uma maior atividade de vigilância deve ser realizada considerando a sazonalidade da doença. Porém, deve-se levar em conta que os hábitos da população podem modificar índices esperados de infestação e de incidência da doença. Portanto, o monitoramento constante desses índices deve ser realizado durante todo o ano, fornecendo informações sobre a transmissão local. 
A realização de um inquérito soro-epidemiológico, que poderia ser feito em crianças da rede escolar de ensino municipal, por exemplo, poderia dar uma idéia da prevalência e dos tipos sorológicos que estão circulando na cidade. Essa informação seria de muita utilidade para a elaboração de estratégias de prevenção e de conhecimento da circulação viral.

O estabelecimento de parcerias entre instituições de ensino e pesquisa e os serviços de vigilância à saúde pode contribuir para um maior conhecimento da dispersão do mosquito no município e compreensão da situação local frente à dengue. Podem, também, contribuir na elaboração de campanhas mais eficazes de prevenção. 


\section{6 - CONCLUSÕES}

A incidência de dengue no município de Santo André mostrou-se maior em indivíduos adultos acima de 50 anos, porém não houve diferença entre os sexos. A incidência foi maior em indivíduos que têm como grau de instrução o ensino médio e menor na população analfabeta, de tal forma que o grau de instrução mais elevado não evita essa doença.

Os casos registrados de dengue no municipio são importados, tendo como principal local de transmissão, com $70 \%$ dos casos, as cidades de Praia Grande, Santos e São Vicente no litoral paulista, sugerindo que essa transmissão tem a haver com a atividade de lazer da população.

O padrão sazonal da incidência dos casos importados e o índice de infestação do vetor, levando-se em consideração os meses do ano, revelaram-se maiores nos primeiros meses do ano, de forma semelhante ao que ocorre em outras regiões do país. Tanto a incidência da doença como o índice de infestação do Aedes aegypti tiveram seu valor aumentado a cada ano, durante o periodo estudado. $O$ fato de não haver transmissão no município merece uma atenção especial, pois pode haver algum fator ou alguma barreira impedindo ou dificultando a autoctonia.

Os primeiros casos de dengue ocorreram em áreas localizadas no limite da cidade com outros municípios. A distribuição mostrou que, até 2002 todas as áreas da região urbana do município apresentaram casos de dengue.

A infestação do Aedes aegypti teve seu início na região da cidade que faz fronteira com o município de São Paulo, local com grande concentração de desmanches e ferro-velho, o que mostra a importância desses locais na dispersão do vetor e a necessidade de mantê-los sob constante vigilância. Até julho de 2003, em todas as áreas urbanas do município, registrou-se a presença do mosquito. 
O índice de infestação apresentou forte correlação positiva com a temperatura, porém baixa correlação com a umidade relativa do ar. $\mathrm{A}$ correlação com a pluviosidade também foi baixa, significando que a disponibilidade de criadouros não depende somente de fatores ecológicos, mas também de ação antrópica. Nesse caso, recipientes mantidos pelo homem, no domicílio, podem servir de criadouro, independentemente dos valores de precipitação.

Vaso, lata, tambor, pneu, material removivel e caixa d'água foram os criadouros encontrados no município de Santo André no período estudado.

Os resultados sugerem que outros fatores podem ser investigados visando a uma estratificação das variáveis que interferem na transmissão da dengue e na infestação do vetor no município de Santo André. 


\section{7 - REFERÊNCIAS}

Albuquerque CMR, Melo-Santos MAV, Bezerra MAS, Barbosa RMR, Silva DF, Silva E. Primeiro registro de Aedes albopictus em área de Mata Atlântica, Recife, Pe, Brasil. Rev Saúde Pública 2000; 34:314-315.

Avilés G, Rangeón G, Vorndam V, Briones A, Baroni P, Enria D e col. Dengue reemergence in Argentina. Emerging Infectious Diseases 2001: 5 (4): 575 578.

Barata EAM, Costa AIP, Chiaravalloti-Neto F, Glasser CM, Barata JMS, Natal D. População de Aedes aegypti (L.) em área endêmica de dengue, Sudeste do Brasil. Rev Saúde Pública 2001; 35:237-242.

Barrera R, Delgado N, Jiménez M, Villalobos I, Romero I. Estratificación de una ciudad hiperendémica en dengue hemorrágico. Rev Panam Salud Publica 2000; 8(4): 225 - 233.

Bastos MS, Figueiredo RMP, Lima MJL, Almeida TCM, Sandoval JJF. Estudo sorológico do dengue no Estado do Amazonas no ano de 2001. In: Anais do $28^{\circ}$ Congresso da Sociedade Brasileira de Medicina Tropical; 2002 fev 24 28; Foz de Iguaçu, Brasil. Sociedade Brasileira de Medicina Tropical; 2002, p. 98.

Benchimol JL. Febre amarela: a doença e a vacina, uma história inacabada. Rio de Janeiro: Fiocruz; 2001. 
Calado DC, Silva MAV. Avaliação da influência da temperatura sobre o desenvolvimento de Aedes albopictus. Rev Saúde Pública 2002; 36(2):173 179.

[CDC] Centers for Disease Control. Biology and control of Aedes aegypti. Atlanta: Centers for Disease Control; 1979.

Chang MS, June N Breeding of Aedes aegypt (L) and Aedes albopictus (Skuse) in urban housing of Sibu Town, Sarawak. South Asian J Trop Med Public Health $1994 ; 25: 543-548$.

Chen WJ, Chen SL, Chien LJ, Chen CC, King CC, Harn MR e col. Silent transmission of dengue virus in Southern Taiwan. Am J Trop Med Hyg 1996; 55: $12-16$.

Chiaravalloti Neto F. Aedes aegypti na região de São José do Rio Preto, Estado de São Paulo. São Paulo; 1992. [ Dissertação de Mestrado Faculdade de Saúde Pública, Universidade de São Paulo].

Chiaravalloti Neto F. Conhecimentos da população sobre dengue, seus vetores e medidas de controle em São José do Rio Preto, São Paulo. Cad Saúde Pública 1997; 13(3): 447 - 453.

Chiaravalloti Neto F, Moraes MS, Fernandes MA. Avaliação dos resultados de atividades de incentivo à participação da comunidade no controle da dengue em um bairro periférico do Município de são José do Rio Preto, São Paulo, e da relação entre conhecimentos e práticas desta população. Cad Saúde Pública 1998; 14 (supl 2) : 101 - 109. 
Chiaravalloti Neto F. Epidemiologia da dengue nas regiões de São José do Rio Preto e Araçatuba, São Paulo, 1990 a 1996. São Paulo; 1999.[Tese de Doutorado - Faculdade de Saúde Pública, Universidade de São Paulo].

Chieffi PP. Algumas questões decorrentes da reintrodução do Aedes aegypti no Brasil. Cad Saúde Pública 1985; 1 (3): 385-387.

Christophers SR. Aedes aegypti (L), The Yellow Fever Mosquito. Cambridge: Cambridge Univ. Press; 1960.

Consoli RAGB, Oliveira RL. Principais mosquitos de importância sanitária no Brasil. Rio de Janeiro: Fiocruz; 1998.

Costa AIP da. Identificação de unidades ambientais urbanas como condicionantes da ocorrência de Aedes aegypti (Diptera: Culicidae) e de dengue na cidade de São José do Rio Preto, S.P., em 1995. São Paulo; 1996. [Dissertação de Mestrado - Faculdade de Saúde Pública, Universidade de São Paulo].

Costa AIP da, Natal D. Distribuição espacial da dengue e determinantes socioeconômicos em localidade urbana no Sudeste do Brasil. Rev Saúde Pública 1998; 32(3): 232-236.

Crovello TJ, Hacker CS. Evolutionary strategies in life table characteristics among feral and urban strains of Aedes aegypti. Evolution 1972; 26:185-96.

Degallier N, Vilarinhos PTR, Carvalho MSL, Knox MB, Caetano Jr J. People's knowledge and practice about dengue, its vectors, and control means in Brasilia (DF), Brazil: its relevance with entomologial factors. Journal of the American Mosquito Control Association 2000; 16(2): 114- 123. 
Dietz VJ, Gluber DJ, Rigau - Pérez JG, Pinheiro F, Schatzmayr HG, Bailey R e col. Epidemic dengue 1 in Brazil, 1986: evaluation of a clinically based dengue surveillance system. American Journal of Epidemiology 1990; 131 (4): 693 701.

Donalisio MR. O dengue no espaço habitado. São Paulo: Hicitec; 1999.

Donalisio MR, Alves MJCP, Visockas A. Inquérito sobre conhecimentos e atitudes da população sobre a transmissão do dengue - região de Campinas São Paulo, Brasil - 1998. Rev Soc Bras Med Trop 2001; 34(2): 197 - 201.

Fernandez E, Lagos I, Shermam C. Advances in the Aedes aegypti communitybased control project in El progreso. Honduras. J Am Mosq Control Assoc 1993; 9: 449.

Figueiredo LTM. History, present and future of dengue fever in Brazil. In: Travassos da Rosa APA, Vasconcelos PFC and Travassos da Rosa JFC. An overview of arbovirology in Brazil and neighbouring contries. Instituto Evandro Chagas; 1998.

Focks DA, Sackett SR, Bayley DL, Dame DA. Observations on container breeding mosquitoes in New Orleans, Lousiana, with na estimate of the population density of Aedes aegypti (L.). Am J Trop Med Hyg 1981; 30: 1329 1335.

Forattini OP. Entomologia Médica. 2. Culicini: Culex, Aedes e Psorophora. São Paulo: EDUSP; 1965

Forattini OP. Qualidade de vida e meio urbano. A cidade de São Paulo, Brasil. Rev Saúde Pública 1991; 25(2): 75-86. 
Forattini OP. Ecologia, epidemiologia e sociedade. São Paulo: Artes Médicas, EDUSP; 1992.

Forattini OP. Culicidologia Médica. São Paulo: EDUSP; 2002.

Forattini OP, Brito $M$ de. Reservatórios domiciliares de água e controle do Aedes aegypti. Rev Saúde Pública 2003; 37(5): 676 - 677.

Franco O. Ministério da Saúde - SUCAM. História da febre amarela no Brasil. Rio de Janeiro; 1976.

[FUNASA] Fundação Nacional de Saúde. Ministério da Saúde. Informe Técnico. Brasilia; 1996.

[FUNASA] Fundação Nacional de Saúde. Número de casos das doenças de notificação compulsória nos anos de 1999 e 2000, por Unidade Federada, Brasil. [on line] Disponivel em <URL: http://www.funasa.gov.br/epi/dengue/dengue0.htm>.[2003 dezembro].

Glasser CM. Estudo da infestação do estado de São Paulo por Aedes aegypti e Aedes albopictus. São Paulo; 1997. [Dissertação de Mestrado Faculdade de Saúde Pública, Universidade de São Paulo].

Glasser CM, Gomes AC. Infestação do estado de São Paulo por Aedes aegypti e Aedes albopictus. Rev Saúde Publica 2000; 34(6): 570 - 577.

Gluber DJ. Aedes aegypti and Aedes aegypti - borne disease control in the 1990s: top down or bottom up. Am J Trop Med Hyg 1989; 40(6) : 571 - 578. 
Gluber DJ, Clark GG. Community - based integrated control of Aedes aegypti: a brief overview of current programs. Am J Trop Med Hyg 1994; 50(6): 50 - 60.

Gomes AC. Mecanismos e significado epidemiológico da domiciliação. Rev Saúde Pública 1986; 20(5): 385 - 390.

Gomes AC. Vigilância Entomológica. Informe Epidemiológico do SUS 2002; 11(2): $79-90$.

Gómez - Dantez H, Montesano - Castellanos R, Lopes - Moreno S. El dengue em México. Situación epidemiológica reciente. Gad Méd Méx 1995a; 131: 237 240.

Gómez - Dantez H, Ramoz - Bonifaz, Tapia - Conyer R. El riesgo de transmisión de dengue: um espacio para la estratificación. Salud Publica Méx 1995b; 37: S88 - S97.

Gratz NG. Emergency control of Aedes Aegypt as a disease vector in urban areas. Journal of the American Mosquito Control Association 1991; 7 (3): $353-365$.

Honório NA, Lourenço - de Oliveira R. Freqüência de larvas e pupas de Aedes aegypti e Aedes albopictus em armadilhas, Brasil. Rev Saúde Pública 2001; 35(4): $385-391$.

Ibanez - Bernal S, Briseno B, Mutebi JP, Argot E, Rodriguez G, Martinez Campos $\mathrm{C}$ e col. First record in America of Aedes albopictus naturally infected with dengue virus during the 1995 outbrek at Reynosa, Mexico. Medical and Veterinary Entomology 1997; 11: 305 - 309. 
[IBGE] Instituto Brasileiro de Geografia e Estatística. Setores Censitários [Disquetes]. São Paulo; 2000.

Jetten TH, Focks DA . Potential changes in distribuition of dengue transmission under climate warming. Am J Trop Med Hyg 1997; 57(3): 285 - 297.

Lima MM. Criadouros de Aedes aegypti encontrados em alguns bairros da cidade do Rio de Janeiro, Rio de Janeiro. Cad Saúde Pública 1988; 4(3):293 300.

Lima VLC de, Figueiredo TM, Correa F, Heleno R e col. Dengue: inquérito sorológico pós - epidêmico em zona urbana do estado de São Paulo (Brasil). Rev Saúde Pública 1999: 33 (6): 566 - 574.

Lobato C, Moraes M, Zacarias A, Moraes MA, Lima F, Costa R. Aspectos epidemiológícos e entomológicos da dengue no Estado do Acre - 2000 - 2001. In: Anais do $28^{\circ}$ Congresso da Sociedade Brasileira de Medicina Tropical; 2002 fev 24 - 28; Foz de Iguaçu, Brasil. Sociedade Brasileira de Medicina Tropical; 2002, p. 87.

Marzochi K B F. Dengue in Brazil - situation, transmission and control - a proposal for ecological control. Mem Inst Oswaldo Cruz 1994; 89 (2): 235 245.

Massad E, Burattini MN, Coutinho FAB e col. Dengue e risco da reintrodução da febre amarela urbana no estado de São Paulo. Rev Saúde Pública 2003; $37(4): 477-484$. 
Melo NV. Estudo dos criadouros de Aedes aegypti na região de Ribeirão Preto, 1985 - 1994. São Paulo; 1997. [Dissertação de Mestrado - Faculdade de Medicina de Ribeirão Preto, Universidade de São Paulo].

Mcintyre NE. Ecology of Urban Arthropods: a Review and a Call to Action. Annals of the Entomologycal Society of America. 2000; 93 (4): 825-35.

McMichael AJ. The urban environment and health in a world of increasing globalization: issues for developing countries. Bulletin of the World Health Organization 2000; 78(9): $1117-1135$.

Moore Cg, Cline BL, Ruíz - Tibén E, Lee D, Romney - Joseph H, Rivera Correa E. Aedes aegypti in Puerto Rico: environmental determinants of larval abundance and relation to dengue virus transmission. Am J Trop Med Hyg 1978; $27: 1225-1231$.

Nascimento CB. A baixa transmissão de dengue na região metropolitana de São Paulo nos contexto das demais regiões do Estado: razões e perspectiva. São Paulo; 2001. [Tese de Doutorado - Faculdade de Saúde Pública, Universidade de São Paulo].

[OPAS] Organização Pan Americana de Saúde. Diretrizes relativas à prevenção e ao controle da dengue e da dengue hemorrágica nas Américas. Washington; 1991.

[OPAS] Organização Pan - Americana de Saúde. Dengue y dengue hemorragico en las Americas: guias para su prevencion y control. Washington; 1995. 
Osanai CH, Rosa APAT, Tang AT, Amaral RS, Passos ADC, Tauil PL. Surto de dengue em Boa Vista, Roraima. Rev Inst Méd Trop São Paulo 1983; 33: 158165.

Penna M L F. Um desafio para a saúde pública brasileira: o controle da dengue. Cad Saúde Pública 2003; 19(1): 305 - 309.

Pereira M, Barbosa GL. Pesquisa larvária e positividade de recipientes com Aedes aegypti e Aedes albopictus no Estado de São Paulo. In: Anais do 310 Congresso da Sociedade de Medicina Tropical; mar; 1995, São Paulo (BR). São Paulo: Sociedade de Medicina Tropical; 1995. P 207.

Pereira M. Produtividade e habitats larvários de Aedes aegypti em Santos, estado de São Paulo. São Paulo; 2001. [Tese de Doutorado - Faculdade de Saúde Pública, Universidade de São Paulo].

Pontes RJS. Estudo da epidemia de dengue no Município de Ribeirão Preto, 1990 - 1991. Ribeirão Preto; 1992. [Tese de Doutorado - Faculdade de Medicina de Ribeirão Preto, Universidade de São Paulo].

Prefeitura do Município de Santo André. Secretaria de Desenvolvimento Urbano. Departamento de Desenvolvimento Urbano. Sumário de Dados de Santo André 2001. Santo André; 2002.

Prefeitura Municipal de Santo André. Coordenadoria de Indicadores Socioeconômicos - CIS. Secretaria de Orçamento e Planejamento Participativo - SOPP. Resultados Censo 2000. Unidade territorial: Bairro. Santo André; 2003. 
Rebelo JMM, Costa JML, Silva FS, Pereira YNO, Silva JM da. Distribuição de Aedes aegypti e do dengue no Estado do Maranhão. Cad Saúde Pública 1999; $15(3): 477-486$.

Rodriguez - Figueiroa L, Rigau - Perez JG, Suarez EL, Reiter P. Risk factors for dengue infection during na outbreak in yanes, Puerto Rico in 1991. Am J Trop Med Hyg 1995; 52: 496 - 502.

Rosa APAT da, Vasconcelos PFC, Rosa EST da, Rodrigues SG, Mondet B, Cruz ACR e col. Dengue epidemic in Belém, Pará, Brazil, 1996 - 97. Emerging Infectious Diseases 2000; 6 (3) : 298 - 301.

Salas - Luévano MA, Reyes - Villanueva F. Variación estacional de las poblaciones de Aedes aegypti en Monterrey, México. Salud Publica 1994; 36: $385-392$.

Santos $\mathrm{OO}$ dos. Estudo epidemiológico da dengue em Maceió, Alagoas, no período de 1997 a 2002. São Paulo; 2003. [Tese de Doutorado - Faculdade de Saúde Pública, Universidade de São Paulo].

São Paulo. Fundação SEADE. Anuário estatístico do Estado de São Paulo. São Paulo; 2003.

São Paulo. Secretaria de Estado da Saúde. Manual de Vigilância Epidemiológica da Dengue. São Paulo; 1987.

São Paulo. Secretaria de Estado da Saúde. Centro de Vigilância Epidemiológica - CVE. Vigilância epidemiológica da dengue no Estado de São Paulo. São Paulo; 1991. 
São Paulo. Secretaria de Estado da Saúde. Centro de Vigilância Epidemiológica - CVE. Casos autóctones de dengue por DIR e Município. Estado de São Paulo. 1995 a 2003. [on line] Disponivel em <URL:http://www.cve.saude.sp.gov.br./dengue_inf2103.htm>. [ 2003 dezembro].

São Paulo. Secretaria de Estado da Saúde - SUCEN. Manual de atividades para controle dos vetores de dengue e febre amarela. São Paulo; 1993.

São Paulo. Secretaria de Estado da Saúde - SUCEN. Plano diretor de erradicação de Aedes aegypti no Estado de Sâo Paulo. São Paulo; 1997.

Serufo JC, Souza AM, Tavares VA e col. Dengue na região sudeste do Brasil : análise histórica e soroepidemiológica. Rev Saúde Pública 1993; 27(3): 157 167.

Severo OP. La erradication del Aedes aegypti em el Brasil evolucion y exito de una gran campaña. Bol Oficina Sant Panam 1959; 47 (1): 1-12.

Slosek J. Aedes aegypti mosquitoes in the Americas: a review of their interaction with the human population. Sci Soc Med 1986; 23 (3):249-57.

Smith DEG. The history of dengue in tropical Asia and its probable relations to the mosquito Aedes aegypti. J Trop Med Hyg 1956; 59:243-51.

Soper FL. Erradication en las americs de los invasores africanos Aedes aegypti y Anopheles ganbiae. Bol Oficina Sanit Panam 1963; 55 (3): 259-66.

Souza-Santos R, Carvalho MS. Análise da distribuição espacial de larvas de Aedes aegypti na liha do Governador, Rio de Janeiro, Brasil. Cad Saúde Pública 2000; 16 (1): $31-42$. 
Tauil PL. Urbanização e ecologia do dengue. Cad Saúde Pública 2001; 17: 99 $-102$.

Teixeira MG, Barreto ML, Guerra Z. Epidemiologia e medidas de prevenção do dengue. Informe Epidemiológico do SUS 1999; 8(4): 5 - 33.

Teixeira MG, Costa MCN, Barreto ML, Barreto FR. Epidemiologia da dengue em Salvador - Bahia, 1995 - 1999. Rev Soc Bras Med Trop 2001; 34 (3):

Trabulsi LR. Microbiologia. São Paulo: Atheneu. 1989.

Tun-Lin W, Mya MM, Than SM, Maung TM. Rapid and efficient removal of immature Aedes aegypti in metal drums by sweep net and modified sweeping method. South Asian J Trop Med Public Health, 1995; 26: 754 -759.

Vasconcelos PFC, Lima JWO, Raposo ML, Rodrigues SG, Rosa JFST e col. Inquérito soro-epidemiológico na llha de São Luiz durante epidemia de dengue no Maranhão. Rev Soc Bras Med Trop 1999; 32:171-179.

Vasconcelos PFC, Mota K, Straatmann A, Santos-Torres S, Rosa APAT, Tavares Neto J. Epidemia de dengue em Ipupiara e Prado, Bahia. Inquérito soro-epidemiológico. Rev Soc Bras Med Trop 2000; 33: 61-67.

Vezzani D, Velázquez SM, Soto S, Schweigmann NJ. Environmental characteristics of the cemeteries of Buenos Aires City (Argentina) and infestation levels of Aedes aegypti (Diptera: Culicidae). Mem Inst Oswaldo Cruz 2001; 96: 3227-3234. 
Watts DM, Burke DS, Harrison BA, Whitemire RE, Nisalak A. Effect of temperature on the vector efficiency of Aedes aegypti for Dengue 2 virus. Am J Trop Med Hyg 1987; 36 (1): 143-152.

[WHO] World Health Organization. Dengue haemorragic fever, diagnosis, treatment and control. Geneve; 1986. 
8 - ANEXOS 
Anexo 1 - Distribuição por tipo de moradia nas áreas do municipio de Santo André em 2000.

\begin{tabular}{cccc}
\hline & \multicolumn{3}{c}{ TIPO DE MORADIA } \\
\cline { 2 - 4 } ÁREA & CASA & APARTAMENTO & OUTROS \\
\hline 1 & 98,8 & 0,5 & 0,7 \\
2 & 96,7 & 2,4 & 0,87 \\
3 & 91,6 & 7,3 & 1,1 \\
4 & 84,5 & 12,6 & 2,9 \\
5 & 98,4 & 0,9 & 0,7 \\
6 & 93,3 & 5,7 & 1 \\
7 & 97,5 & 0,8 & 1,7 \\
8 & 87,7 & 11,6 & 0,8 \\
9 & 50,6 & 46,5 & 2,9 \\
10 & 77,4 & 20,7 & 1,9 \\
11 & 78,9 & 15,3 & 5,8 \\
12 & 83,7 & 13,2 & 3,1 \\
13 & 49,6 & 49,2 & 1,2 \\
14 & 79,4 & 16,5 & 4,1 \\
15 & 91,1 & 6 & 2,9 \\
16 & 70,8 & 14,2 & 15 \\
17 & 93,5 & 3,7 & 2,8 \\
18 & 94,8 & 3,9 & 1,3 \\
19 & 93,4 & 6,8 & 0,8 \\
20 & 92,5 & 3,7 & 3,8 \\
21 & 92,1 & 7 & 0,9 \\
22 & 95,8 & 2,5 & 1,7 \\
\hline Fon & 9,8 & \\
\hline
\end{tabular}

Fonte: Departamento de Indicadores Sócio Econômicos - Secretaria do Planejamento PMSA - IBGE 
Anexo 2 - Densidade populacional por área e por ano em Santo André

\begin{tabular}{ccccccc}
\hline & \multicolumn{6}{c}{ ANO } \\
\cline { 2 - 7 } ÁREA & $\mathbf{1 9 9 8}$ & $\mathbf{1 9 9 9}$ & $\mathbf{2 0 0 0}$ & $\mathbf{2 0 0 1}$ & $\mathbf{2 0 0 2}$ & $\mathbf{2 0 0 3}$ \\
\hline 1 & 11981 & 11838 & 11684 & 11535 & 11387 & 11011 \\
2 & 7674 & 7774 & 7875 & 7976 & 8078 & 8174 \\
3 & 11843 & 11565 & 11417 & 11267 & 11118 & 10971 \\
4 & 7458 & 7345 & 7236 & 7127 & 7017 & 6910 \\
5 & 11813 & 11696 & 11580 & 11462 & 11346 & 11231 \\
6 & 12701 & 13235 & 13769 & 14303 & 14847 & 15390 \\
7 & 8296 & 8180 & 8065 & 7947 & 7834 & 7721 \\
8 & 6978 & 6988 & 6997 & 7007 & 7017 & 7203 \\
9 & 1700 & 1646 & 1591 & 1537 & 1483 & 1431 \\
10 & 5808 & 5767 & 5725 & 5684 & 5642 & 5601 \\
11 & 13533 & 13438 & 13345 & 13251 & 13158 & 13065 \\
12 & 8621 & 8663 & 8705 & 8747 & 8789 & 8832 \\
13 & 9284 & 9242 & 9199 & 9157 & 9115 & 9073 \\
14 & 7428 & 7413 & 7397 & 7382 & 7366 & 7350 \\
15 & 9454 & 9222 & 8989 & 8758 & 8526 & 8300 \\
16 & 11546 & 11710 & 11875 & 12040 & 12204 & 12371 \\
17 & 16105 & 16516 & 16927 & 17338 & 17749 & 18169 \\
18 & 8440 & 8319 & 8197 & 8075 & 7952 & 7832 \\
19 & 12379 & 12002 & 11626 & 11249 & 10877 & 10509 \\
20 & 9556 & 9693 & 9831 & 10058 & 10107 & 10247 \\
21 & 122263 & 13128 & 13993 & 14859 & 15724 & 16640 \\
22 & 1246 & 1350 & 1454 & 1557 & 1661 & 1772 \\
\hline
\end{tabular}

Fonte: Departamento de Indicadores Sócio Econômicos - Secretaria do Planejamento PMSA - IBGE 
Anexo 3 - Renda média e índice de alfabetização por área no município de Santo André

\begin{tabular}{ccc}
\hline ÁREA & $\begin{array}{c}\text { ÍNDICE DE } \\
\text { ALFABETIZAÇÃO }\end{array}$ & $\begin{array}{c}\text { RENDA SALARIAL } \\
\text { SALÁRIO MíNIMO }\end{array}$ \\
\hline 1 & 94,4 & 4,1 \\
2 & 93,9 & 3,9 \\
3 & 95,1 & 4,7 \\
4 & 93,6 & 4,2 \\
5 & 93,2 & 3,5 \\
6 & 91,5 & 3,3 \\
7 & 92,8 & 3,9 \\
8 & 96,3 & 6,3 \\
9 & 97,2 & 6,9 \\
10 & 96,7 & 9,4 \\
11 & 92,5 & 4,6 \\
12 & 94,7 & 6,1 \\
13 & 97,6 & 12,7 \\
14 & 93,5 & 6,4 \\
15 & 95,5 & 5,5 \\
16 & 94,2 & 4,1 \\
17 & 90,7 & 3,1 \\
18 & 96,2 & 5,3 \\
19 & 93,9 & 4,1 \\
20 & 90,7 & 3,1 \\
21 & 90,8 & 2,8 \\
22 & 89,2 & 2,2 \\
\hline
\end{tabular}

Fonte: Departamento de Indicadores Sócio Econômicos - Secretaria do Planejamento PMSA - IBGE 
Anexo 4 - Número de casos importados de dengue em Santo André, segundo o estado brasileiro de origem, de 1999 a 2002.

\begin{tabular}{lccccc}
\hline \multirow{2}{*}{ ESTADO } & \multicolumn{5}{c}{ ANO } \\
\cline { 2 - 6 } \multicolumn{1}{c}{$\mathbf{1 9 9 9}$} & $\mathbf{2 0 0 0}$ & $\mathbf{2 0 0 1}$ & $\mathbf{2 0 0 2}$ & TOTAL \\
\hline Tocantins & 0 & 0 & 0 & 2 & 2 \\
Ceara & 0 & 0 & 1 & 0 & 1 \\
Alagoas & 1 & 0 & 1 & 0 & 2 \\
Bahia & 1 & 11 & 12 & 10 & 34 \\
Paraná & 3 & 6 & 2 & 23 & 34 \\
São Paulo & 4 & 2 & 8 & 116 & 130 \\
Mato Grosso do Sul & 0 & 1 & 11 & 24 & 36 \\
Mato Grosso & 0 & 3 & 11 & 5 & 19 \\
\hline
\end{tabular}

Fonte: Departamento de Vigiláncia à Saúde - Santo André 
Anexo 5 - Distribuição dos casos de dengue importados segundo a cidade do estado de São Paulo de origem dos casos, de 1999 a 2002.

\begin{tabular}{|c|c|c|c|c|c|}
\hline \multirow[b]{2}{*}{ CIDADES } & \multicolumn{5}{|c|}{ ANO } \\
\hline & 1999 & 2000 & 2001 & 2002 & TOTAL \\
\hline Águas da Prata & 0 & 0 & 0 & 1 & 1 \\
\hline Águas de Santa Bárbara & 1 & 0 & 0 & 0 & 1 \\
\hline Barra Bonita & 0 & 1 & 0 & 0 & 1 \\
\hline Barretos & 0 & 0 & 1 & 0 & 1 \\
\hline Bertioga & 0 & 0 & 0 & 1 & 1 \\
\hline Birigui & 0 & 0 & 0 & 1 & 1 \\
\hline Boracéia & 1 & 0 & 0 & 0 & 1 \\
\hline Diadema & 0 & 0 & 0 & 1 & 1 \\
\hline Guarujá & 0 & 0 & 1 & 1 & 2 \\
\hline Itanhaém & 0 & 0 & 0 & 1 & 1 \\
\hline Itapevi & 0 & 0 & 0 & 1 & 1 \\
\hline Itápolis & 0 & 0 & 1 & 0 & 1 \\
\hline Mauá & 0 & 0 & 0 & 4 & 4 \\
\hline Mongaguá & 0 & 1 & 0 & 1 & 2 \\
\hline Peruibe & 0 & 0 & 0 & 2 & 2 \\
\hline Piracicaba & 0 & 0 & 1 & 0 & 1 \\
\hline Praia Grande & 0 & 0 & 0 & 65 & 65 \\
\hline Santo André & 0 & 0 & 0 & 2 & 2 \\
\hline Santos & 1 & 0 & 3 & 16 & 20 \\
\hline São Bernardo do Campo & 0 & 0 & 0 & 4 & 4 \\
\hline São José do Rio Preto & 1 & 0 & 0 & 0 & 1 \\
\hline São Paulo & 0 & 0 & 0 & 4 & 4 \\
\hline São Vicente & 0 & 0 & 0 & 5 & 5 \\
\hline Teodoro Sampaio & 0 & 0 & 0 & 1 & 1 \\
\hline Ubatuba & 0 & 0 & 0 & 1 & 1 \\
\hline
\end{tabular}


Anexo 6 - Distribuição dos casos de dengue no município de Santo André segundo a área, de 1999 a 2002.

\begin{tabular}{ccccc}
\hline & \multicolumn{4}{c}{ ANO } \\
\cline { 2 - 5 } ÁREA & $\mathbf{1 9 9 9}$ & $\mathbf{2 0 0 0}$ & $\mathbf{2 0 0 1}$ & $\mathbf{2 0 0 2}$ \\
\hline 1 & 1 & 1 & 3 & 2 \\
2 & 1 & 5 & 1 & 1 \\
3 & 2 & 0 & 0 & 0 \\
4 & 1 & 0 & 0 & 1 \\
5 & 0 & 1 & 1 & 5 \\
6 & 0 & 1 & 3 & 2 \\
7 & 0 & 0 & 0 & 1 \\
8 & 0 & 0 & 1 & 1 \\
9 & 0 & 0 & 1 & 0 \\
10 & 1 & 0 & 0 & 1 \\
11 & 2 & 0 & 0 & 1 \\
12 & 1 & 0 & 1 & 0 \\
13 & 0 & 0 & 1 & 1 \\
14 & 1 & 0 & 2 & 5 \\
15 & 0 & 1 & 5 & 1 \\
16 & 0 & 0 & 2 & 0 \\
17 & 0 & 0 & 1 & 0 \\
18 & 0 & 0 & 2 & 0 \\
19 & 0 & 1 & 1 & 0 \\
20 & 0 & 0 & 1 & 1 \\
21 & 0 & 0 & 2 & 0 \\
22 & 0 & 4 & 1 & 1 \\
\hline
\end{tabular}

Fonte: Departamento de Vigilância à Saúde - Santo André 
Anexo 7 - Distribuição dos pontos estratégicos no município

Santo André de acordo com sua classificação, no ano de 2003.

\begin{tabular}{|c|c|c|c|c|c|c|c|}
\hline$\frac{\mathscr{Z}}{\mathbb{d}}$ & 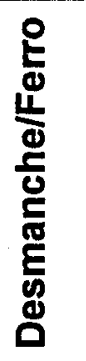 & 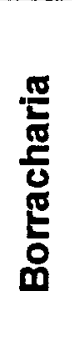 & $\frac{\text { 은 }}{\stackrel{\Phi}{\underline{\Phi}}}$ & $\frac{8}{0}$ & 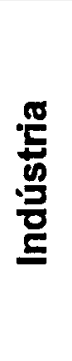 & 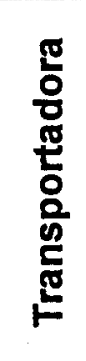 & $\begin{array}{l}\bar{\Phi} \\
\stackrel{0}{0}\end{array}$ \\
\hline 1 & 19 & 0 & 0 & 1 & 1 & .1 & 22 \\
\hline 2 & 4 & 0 & 0 & 0 & 0 & 0 & 4 \\
\hline 3 & 0 & 0 & 0 & 0 & 0 & 0 & 0 \\
\hline 4 & 11 & 0 & 0 & 1 & 0 & 2 & 14 \\
\hline 5 & 1 & 1 & 1 & 0 & 0 & 1 & 4 \\
\hline 6 & 2 & 1 & 0 & 0 & 0 & 0 & 3 \\
\hline 7 & 1 & 0 & 0 & 0 & 0 & 0 & 1 \\
\hline 8 & 6 & 0 & 1 & 1 & 1 & 0 & 9 \\
\hline 9 & 1 & 1 & 0 & 1 & 2 & 0 & 5 \\
\hline 10 & 2 & 0 & 0 & 0 & 0 & 0 & 2 \\
\hline 11 & 2 & 1 & 0 & 1 & 2 & 0 & 6 \\
\hline 12 & 1 & 0 & 0 & 1 & 2 & 1 & 5 \\
\hline 13 & 0 & 0 & 0 & 0 & 0 & 0 & 0 \\
\hline 14 & 0 & 0 & 1 & 2 & 0 & 1 & 4 \\
\hline 15 & 2 & 1 & 0 & 0 & 0 & 0 & 3 \\
\hline 16 & 2 & 1 & 0 & 0 & 0 & 0 & 3 \\
\hline 17 & 7 & 0 & 0 & 0 & 0 & 0 & 7 \\
\hline 18 & 1 & 0 & 1 & 0 & 0 & 0 & 2 \\
\hline 19 & 1 & 1 & 1 & 0 & 0 & 0 & 3 \\
\hline 20 & 3 & 1 & 0 & 1 & 0 & 0 & 5 \\
\hline 21 & 13 & 1 & 0 & 0 & 0 & 0 & 14 \\
\hline 22 & 4 & 0 & 0 & 2 & 0 & 0 & 6 \\
\hline
\end{tabular}


Anexo 8 - Valores mensais do Índice Predial, temperatura, Umidade Relativa do Ar e Precipitação no ano de 2001 em Santo André.

\begin{tabular}{ccccccc}
\hline Mês & ip & $\begin{array}{c}\text { Temp }\left({ }^{\circ} \mathbf{C}\right) \\
\text { média }\end{array}$ & $\begin{array}{c}\text { Temp }\left({ }^{\circ} \mathbf{C}\right) \\
\text { minima }\end{array}$ & $\begin{array}{c}\text { Temp }\left({ }^{\circ} \mathrm{C}\right) \\
\text { máxima }\end{array}$ & $\begin{array}{c}\text { Umidade } \\
(\%)\end{array}$ & $\begin{array}{c}\text { Precipitação } \\
\left(\mathbf{m m ~ H} \mathbf{H}_{\mathbf{2}} \mathbf{0}\right)\end{array}$ \\
\hline jan & 0,145 & 24,35 & 19,87 & 31,65 & 80,14 & 138,6 \\
fev & 0,261 & 24,43 & 20,34 & 31,21 & 84,66 & 155,2 \\
mar & 0,176 & 23,63 & 19,35 & 30,97 & 83,75 & 198,3 \\
abr & 0,182 & 22,94 & 18,09 & 29,77 & 75,60 & 43,9 \\
mai & 0,048 & 17,91 & 14,42 & 22,49 & 84,95 & 90,6 \\
jun & 0,038 & 17,83 & 13,65 & 23,67 & 84,22 & 26,4 \\
jul & 0,034 & 16,87 & 11,96 & 23,80 & 79,11 & 60,9 \\
ago & 0,032 & 18,35 & 13,39 & 26,50 & 76,81 & 22,7 \\
set & 0,034 & 18,47 & 14,07 & 24,84 & 81,72 & 55,1 \\
out & 0,065 & 20,05 & 15,43 & 27,64 & 78,91 & 244,4 \\
nov & 0,062 & 21,68 & 18,03 & 28,70 & 83,59 & 116,7 \\
dez & 0,068 & 21,96 & 18,39 & 27,79 & 86,07 & 171,0 \\
\hline \multicolumn{5}{c}{ Fonte: DVS-AS-CETESB-EMPLASA } \\
\hline
\end{tabular}

Fonte: DVS-AS - CETESB - EMPLASA 
Anexo 9 - Valores mensais de índice predial, temperatura, umidade relativa do ar e precipitação, no ano de 2002 em Santo André.

\begin{tabular}{ccccccc}
\hline Mês & ip & $\begin{array}{c}\text { temp }\left({ }^{\circ} \mathrm{C}\right) \\
\text { média }\end{array}$ & $\begin{array}{c}\text { temp }\left({ }^{\circ} \mathrm{C}\right) \\
\text { minima }\end{array}$ & $\begin{array}{c}\text { temp }\left({ }^{\circ} \mathrm{C}\right) \\
\text { máxima }\end{array}$ & $\begin{array}{c}\text { umidade } \\
\text { (\%) }\end{array}$ & $\begin{array}{c}\text { precipitação } \\
\text { (mm H20) }\end{array}$ \\
\hline jan & 0,169 & 23,07 & 19,18 & 29,39 & 85,45 & 138,5 \\
fev & 0,194 & 23,26 & 18,52 & 28,03 & 86,46 & 172,0 \\
mar & 0,161 & 24,77 & 20,22 & 31,86 & 80,07 & 161,8 \\
abr & 0,211 & 23,61 & 19,29 & 30,43 & 78,04 & 48,5 \\
mai & 0,197 & 19,69 & 15,71 & 26,12 & 84,21 & 70,2 \\
jun & 0,090 & 19,61 & 15,07 & 26,48 & 76,57 & 5,6 \\
jul & 0,094 & 16,20 & 12,01 & 23,02 & 82,24 & 37,9 \\
ago & 0,059 & 20,37 & 15,35 & 28,26 & 73,68 & 48,2 \\
set & 0,024 & 17,92 & 13,40 & 24,78 & 80,31 & 66,8 \\
out & 0,090 & 23,46 & 17,99 & 31,77 & 74,97 & 125,8 \\
nov & 0,175 & 22,52 & 17,78 & 29,44 & 81,90 & 217,8 \\
dez & 0,173 & 23,70 & 19,18 & 30,38 & 81,81 & 136,3 \\
\hline
\end{tabular}


Anexo 10 - Valores mensais de índice de infestação, temperatura, umidade relativa do ar e precipitação até julho de 2003, em Santo André.

\begin{tabular}{ccccccc}
\hline Mês & ip & \multicolumn{2}{c}{ temp $\left({ }^{\circ} \mathrm{C}\right)$} & temp $\left({ }^{\circ} \mathrm{C}\right)$ & temp $\left({ }^{\circ} \mathrm{C}\right)$ & umidade precipitação \\
& & média & minima & máxima & (\%) & (mm H20) \\
\hline jan & 0,120 & 23,22 & 19,30 & 28,76 & 86,57 & 265,3 \\
fev & 0,211 & 26,03 & 21,02 & 33,46 & 76,13 & 160,7 \\
mar & 0,329 & 22,90 & 18,94 & 29,09 & 85,59 & 110,8 \\
abr & 0,255 & 21,64 & 17,30 & 27,72 & 82,66 & 87,6 \\
mai & 0,215 & 18,47 & 13,84 & 24,88 & 77,30 & 20,6 \\
jun & 0,103 & 19,18 & 14,46 & 26,41 & 78,74 & 20,4 \\
jul & 0,064 & 17,73 & 12,80 & 24,58 & 74,13 & 19,8 \\
\hline \multicolumn{5}{c}{ Fonte: DVS-AS-CETESB-EMPLASA } \\
\hline
\end{tabular}




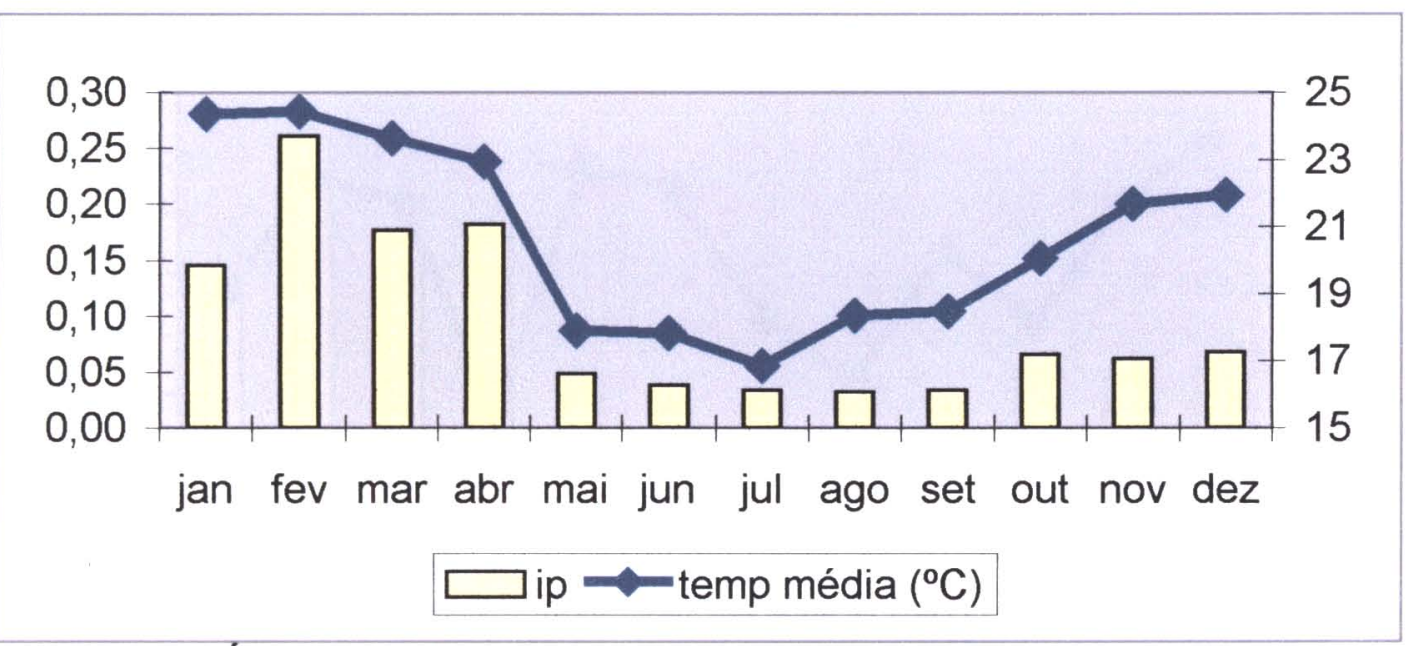

Anexo 11 - Índice predial e temperatura média em 2001

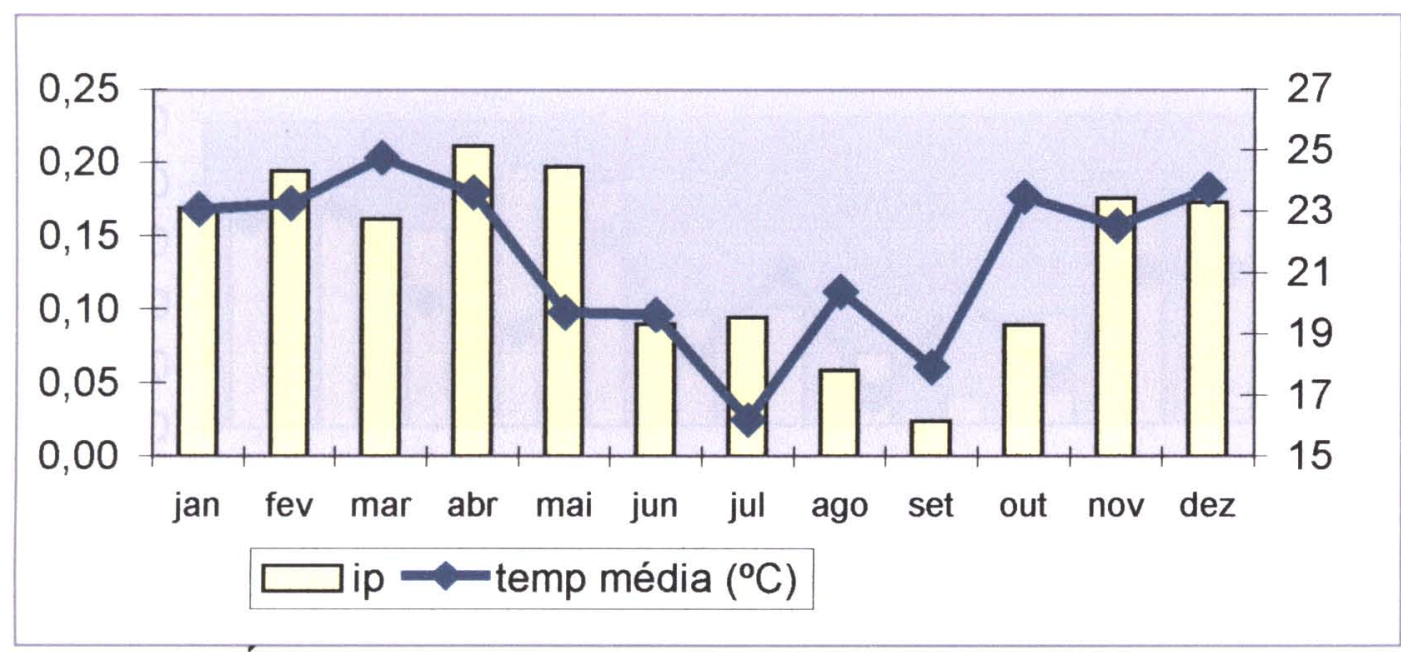

Anexo 12 - Índice predial e temperatura média em 2002

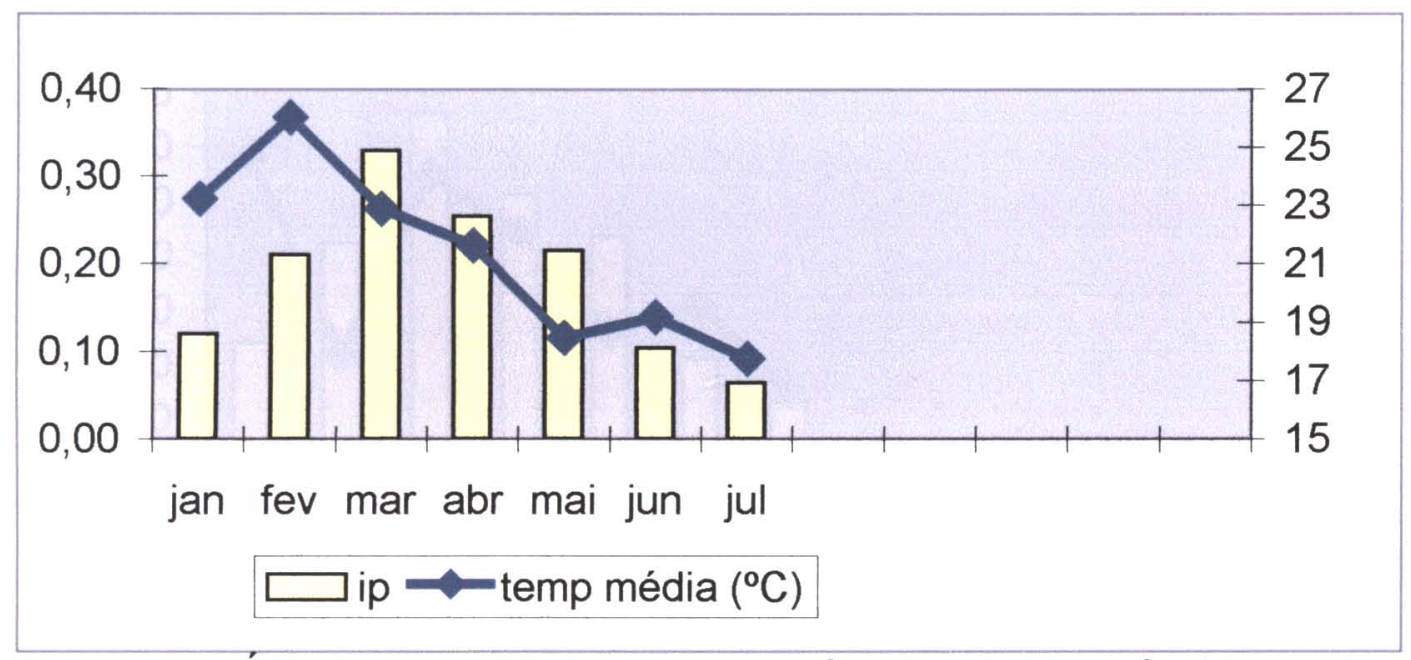

Anexo 13 - Índice predial e temperatura média em 2003 (até julho) 


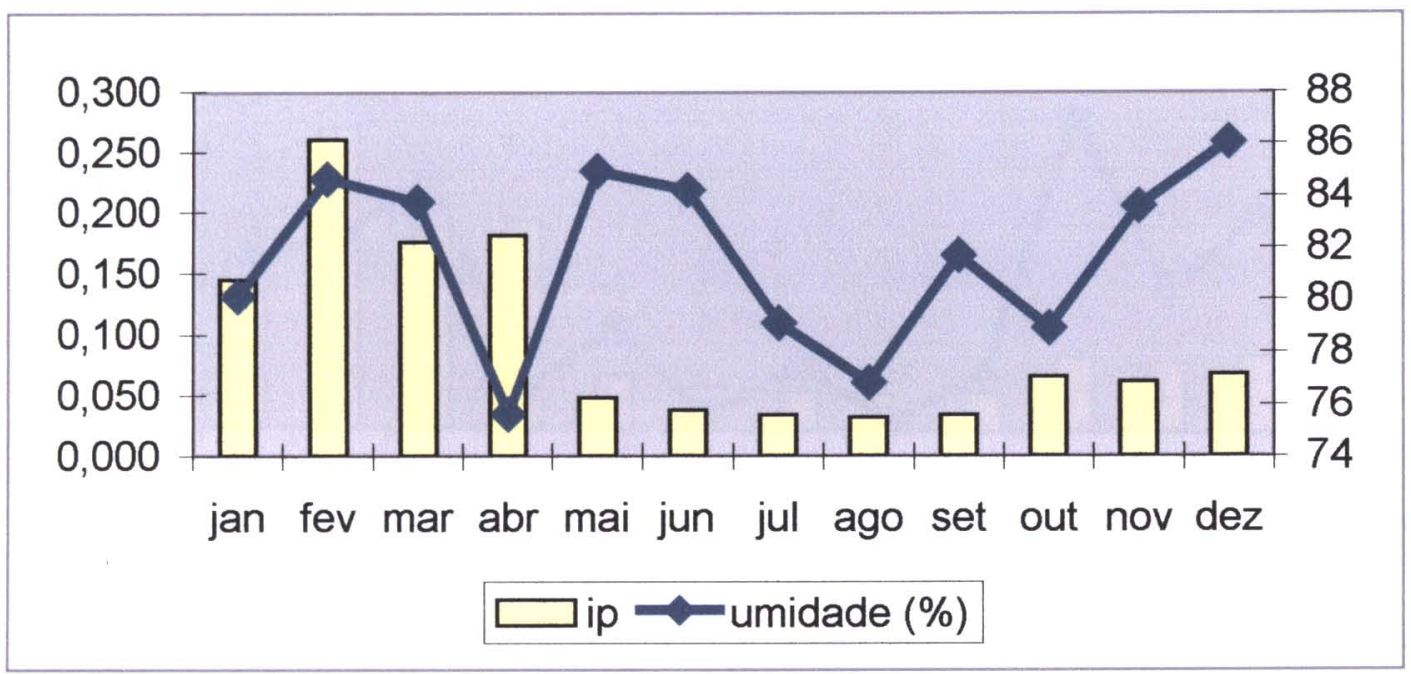

Anexo 14 - Índice predial e umidade relativa do ar em 2001

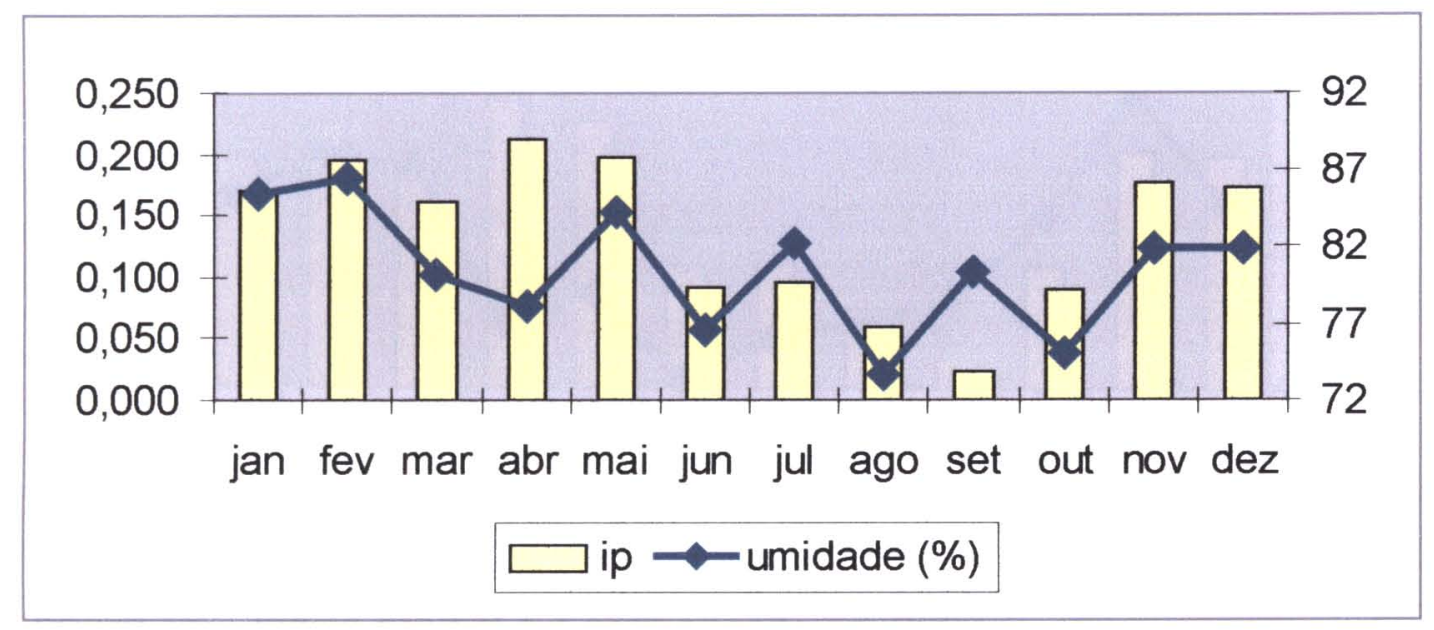

Anexo 15- Índice predial e umidade relativa do ar em 2002

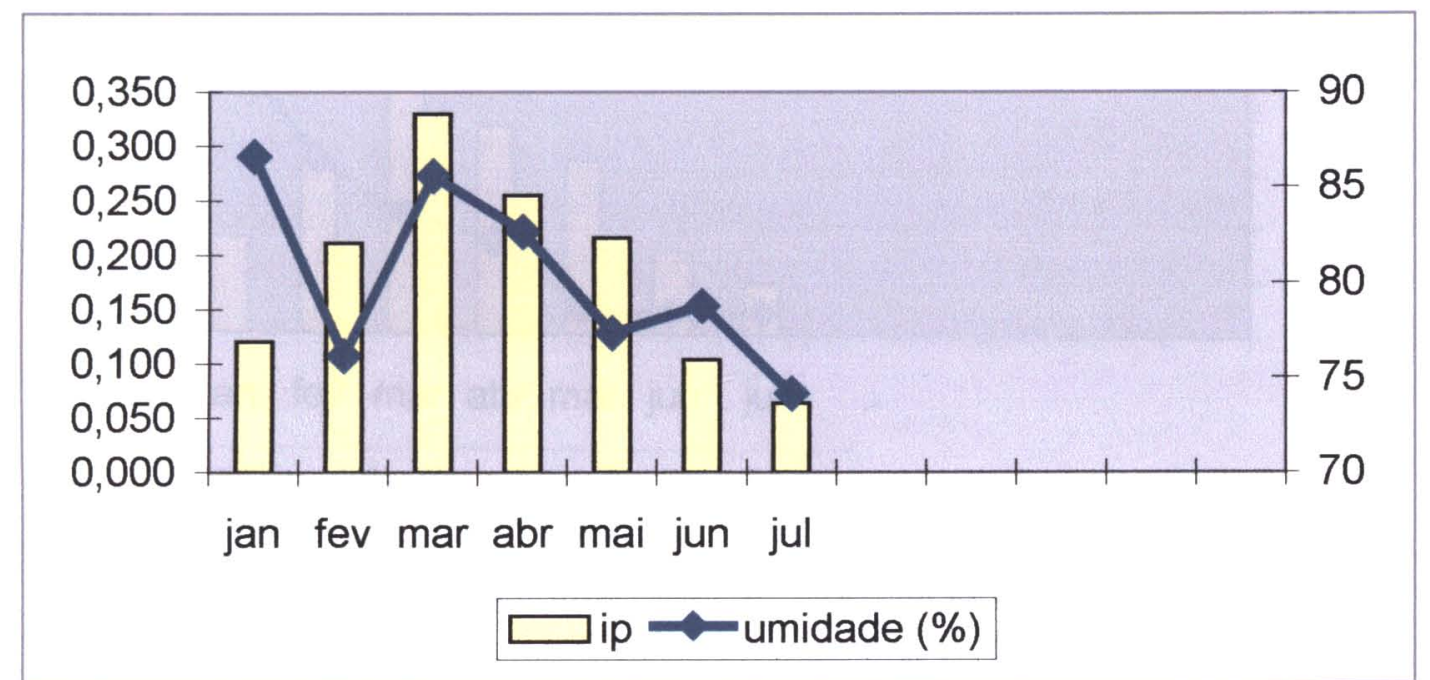

Anexo 16- Índice predial e umidade relativa do ar em 2003 (até julho) 


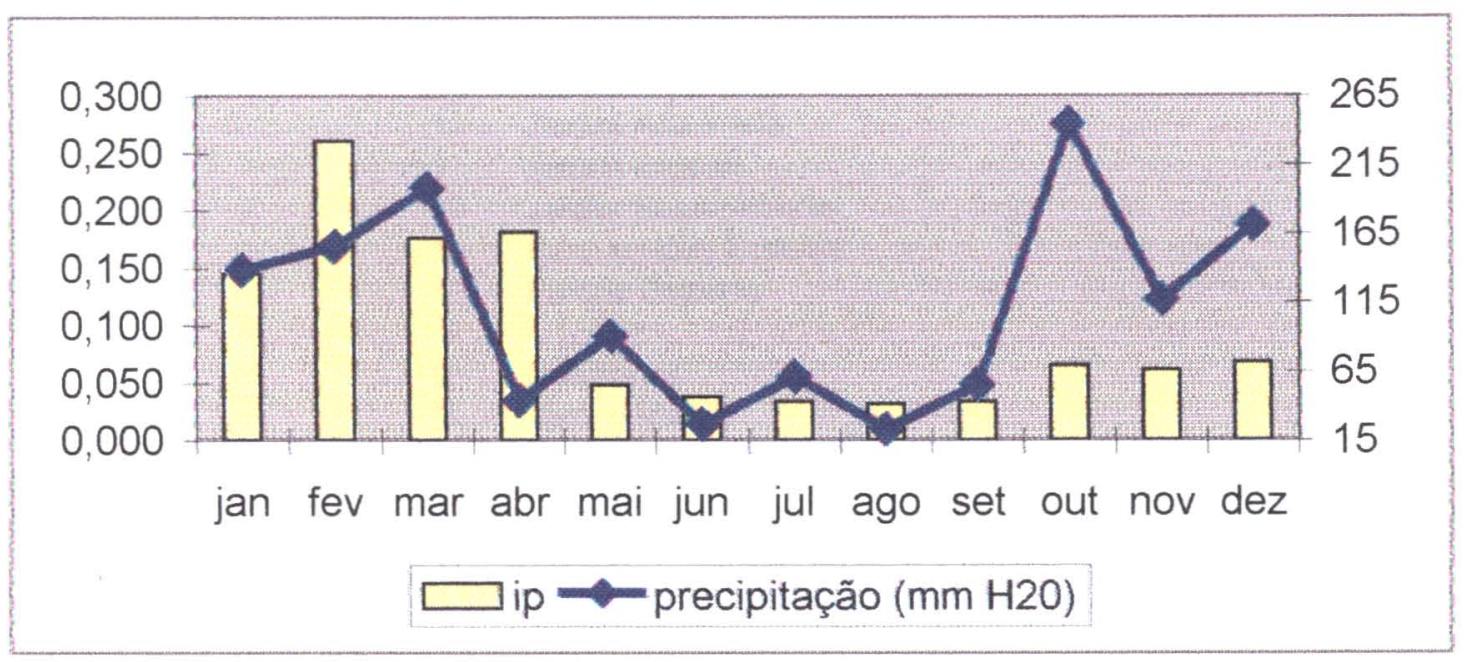

Anexo 17 - Índice predial e a precipitação em 2001

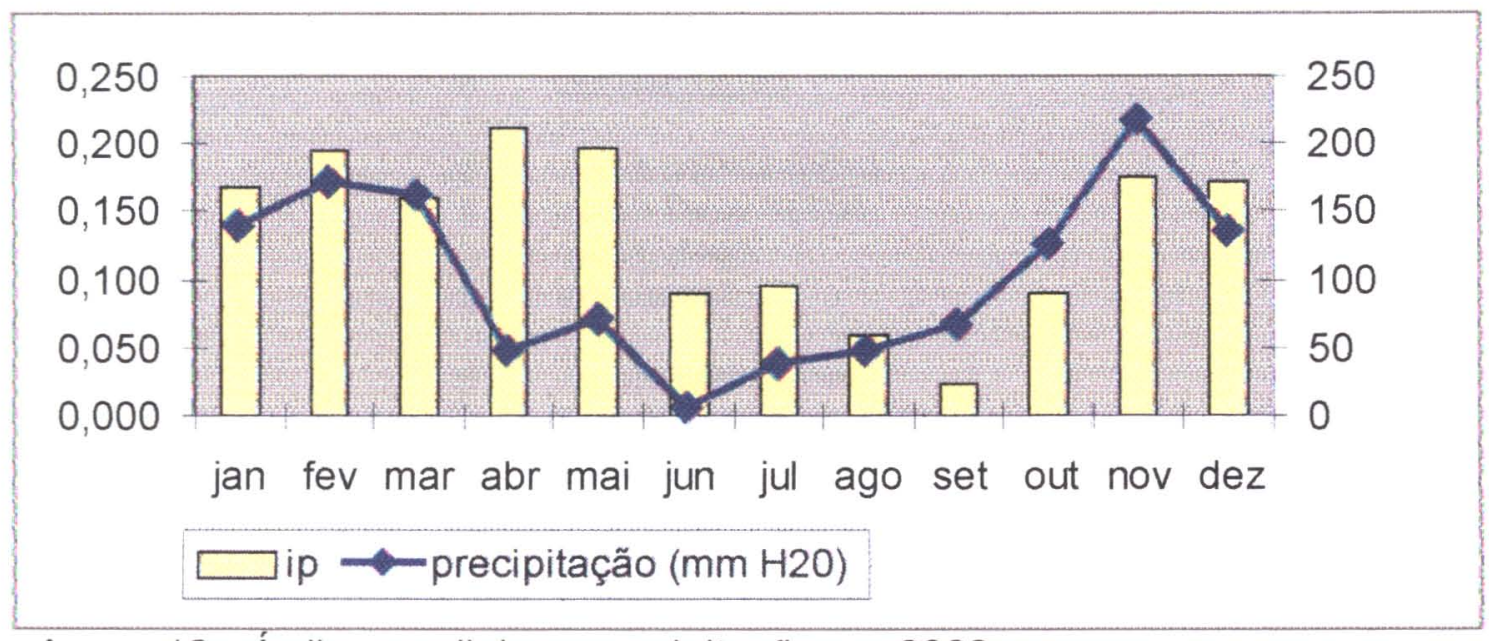

Anexo 18 - Índice predial e a precipitação em 2002.

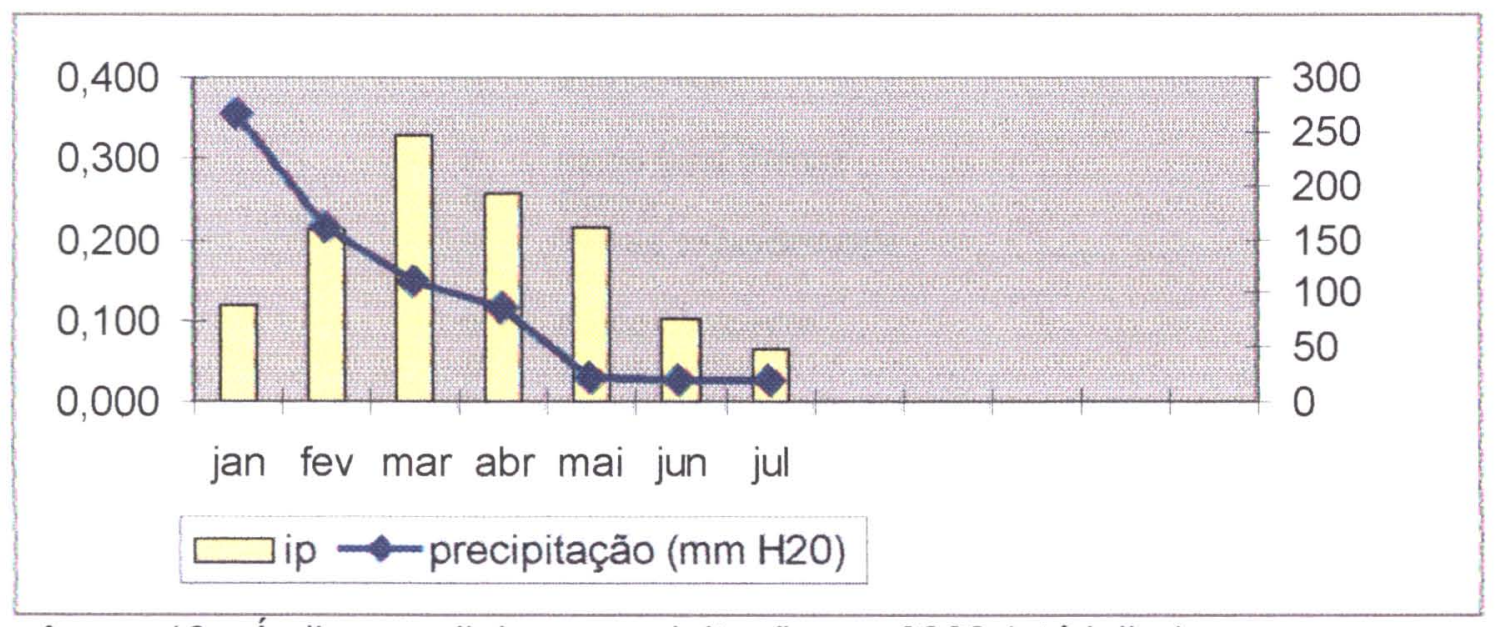

Anexo 19 - Índice predial e a precipitação em 2003 (até julho). 
Anexo 20 - Áreas e distribuição dos bairros em Santo André.

\begin{tabular}{|c|c|}
\hline Área & Bairro \\
\hline 1 & Jardim Ana Maria \\
\hline 1 & Jardim Itapoan \\
\hline 1 & Jardim Santo Alberto \\
\hline 1 & Parque Novo Oratorio \\
\hline 1 & Parque Oratorio \\
\hline 2 & Centreville \\
\hline 2 & Jardim Marek \\
\hline 2 & Parque Marajoara \\
\hline 2 & Vila America \\
\hline 2 & Vila Guarani \\
\hline 2 & Vila Homero Thon \\
\hline 2 & Vila Humaita \\
\hline 3 & Parque das Naçסes \\
\hline 3 & Vila Francisco Matarazzo \\
\hline 4 & Vila Camilopolis \\
\hline 4 & Vila Metalurgica \\
\hline 5 & Jardim das Maravilhas \\
\hline 5 & Jardim Santo Antonio \\
\hline 5 & Jardim Utinga \\
\hline 5 & Vila Lucinda \\
\hline 6 & Jardim Alzira Franco \\
\hline 6 & Parque Erasmo Assunção \\
\hline 6 & Parque Joåo Ramalho \\
\hline 7 & Jardim Rina \\
\hline 7 & Parque Capuava \\
\hline 8 & Bairro Santa Terezinha \\
\hline 8 & Bangu \\
\hline 8 & Parque Jaçatuba \\
\hline 8 & Vila Curuça \\
\hline 9 & Bairro Casa Branca \\
\hline 9 & Centro \\
\hline 9 & Varzea do tamanduatei \\
\hline 10 & Bairro Campestre \\
\hline 10 & Bairro Jardim \\
\hline 10 & Bairro Santa Maria \\
\hline
\end{tabular}




\begin{tabular}{|c|c|}
\hline $\begin{array}{l}\text { Área } \\
11 \\
11 \\
11 \\
11 \\
11\end{array}$ & $\begin{array}{l}\text { Bairro } \\
\text { Vila Alpina } \\
\text { Vila Aquilino } \\
\text { Vila Guiomar } \\
\text { Vila Palmares } \\
\text { Vila Sacadura Cabral }\end{array}$ \\
\hline $\begin{array}{l}12 \\
12 \\
12\end{array}$ & $\begin{array}{l}\text { Vila Floresta } \\
\text { Vila Principe de Gales } \\
\text { Vila Valparaiso }\end{array}$ \\
\hline $\begin{array}{l}13 \\
13 \\
13 \\
13\end{array}$ & $\begin{array}{l}\text { Jardim Bela Vista } \\
\text { Vila Alice } \\
\text { Vila Bastos } \\
\text { Vila Gilda }\end{array}$ \\
\hline $\begin{array}{l}14 \\
14\end{array}$ & $\begin{array}{l}\text { Bairro Paraiso } \\
\text { Vila Assunção }\end{array}$ \\
\hline $\begin{array}{l}15 \\
15 \\
15 \\
15 \\
15\end{array}$ & $\begin{array}{l}\text { Jardim Bom Pastor } \\
\text { Jardim Jamaica } \\
\text { Jardim Stella } \\
\text { Pinheirinho } \\
\text { Vila Scarpelli }\end{array}$ \\
\hline $\begin{array}{l}16 \\
16 \\
16 \\
16 \\
16\end{array}$ & $\begin{array}{l}\text { Jardim Alvorada } \\
\text { Jardim Cristiane } \\
\text { Jardim Las Vegas } \\
\text { Jardim Milena } \\
\text { Jardim Oriental }\end{array}$ \\
\hline $\begin{array}{l}17 \\
17 \\
17 \\
17\end{array}$ & $\begin{array}{l}\text { Jardim do Estadio } \\
\text { Jardim Santa Cristina } \\
\text { Jardim Telles de Menezes } \\
\text { Vila Linda }\end{array}$ \\
\hline $\begin{array}{l}18 \\
18 \\
18 \\
18 \\
18\end{array}$ & $\begin{array}{l}\text { Bairro Silveira } \\
\text { Vila Alzira } \\
\text { Vila Helena } \\
\text { Vila Marina } \\
\text { Vila Pires }\end{array}$ \\
\hline $\begin{array}{l}19 \\
19 \\
19 \\
19 \\
19 \\
19\end{array}$ & $\begin{array}{l}\text { Jardim Ipanema } \\
\text { Vila Junqueira } \\
\text { Vila Lutecia } \\
\text { Vila Suiça } \\
\text { Vila Tibiriça } \\
\text { Vila Vitória }\end{array}$ \\
\hline
\end{tabular}




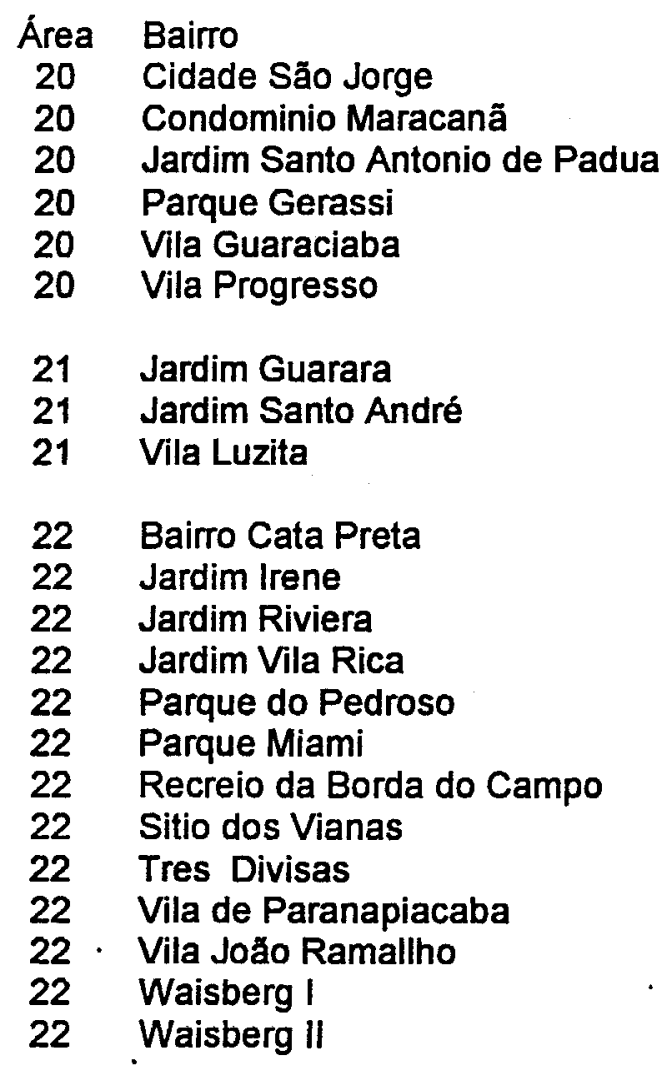


República Federativa do Brasil Ministério da Saúde
SINAN

Sistam AE INFORMaclo DE ACRAVOS DE Notiricaclo rich oeinestrencio DENGUE

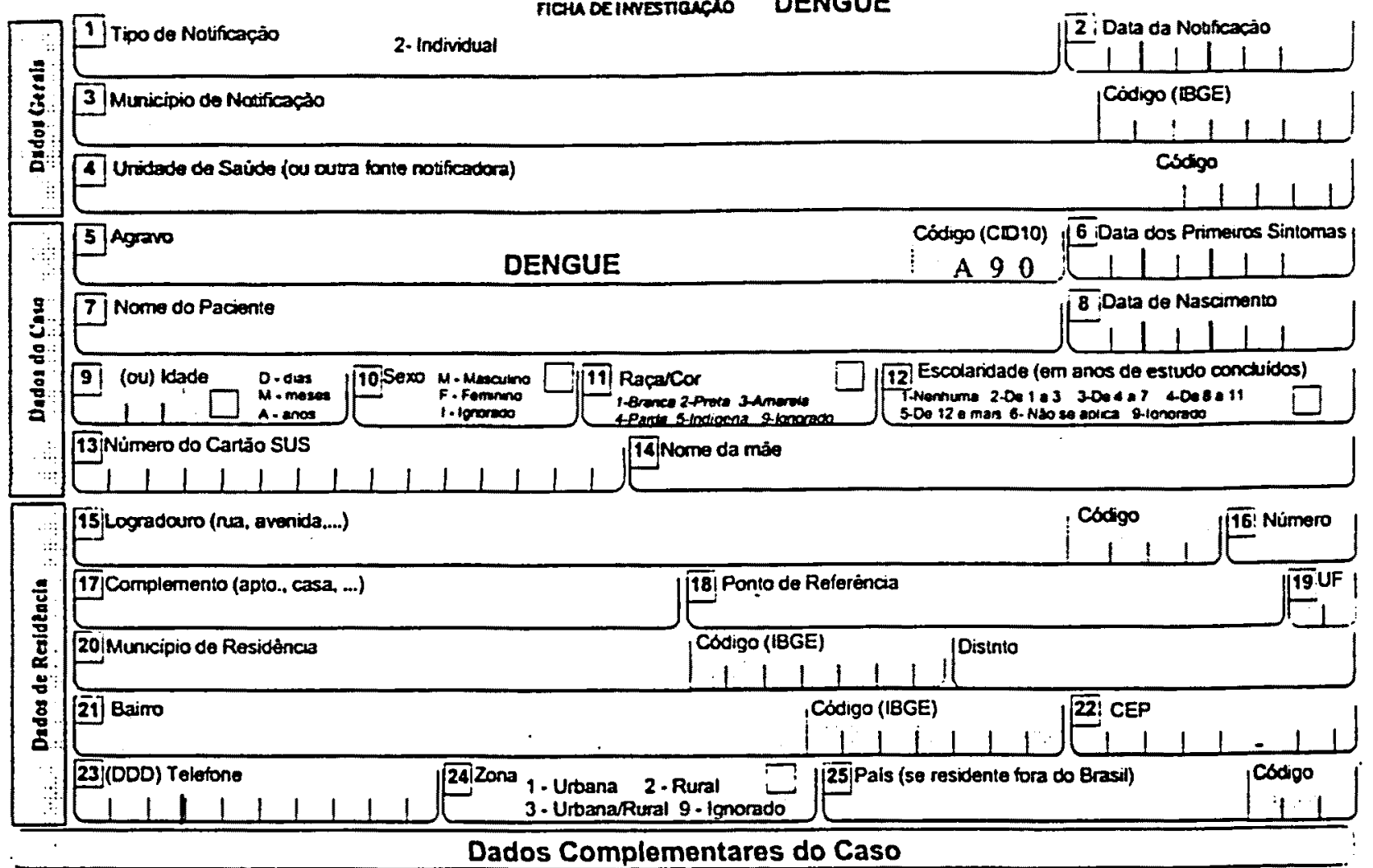

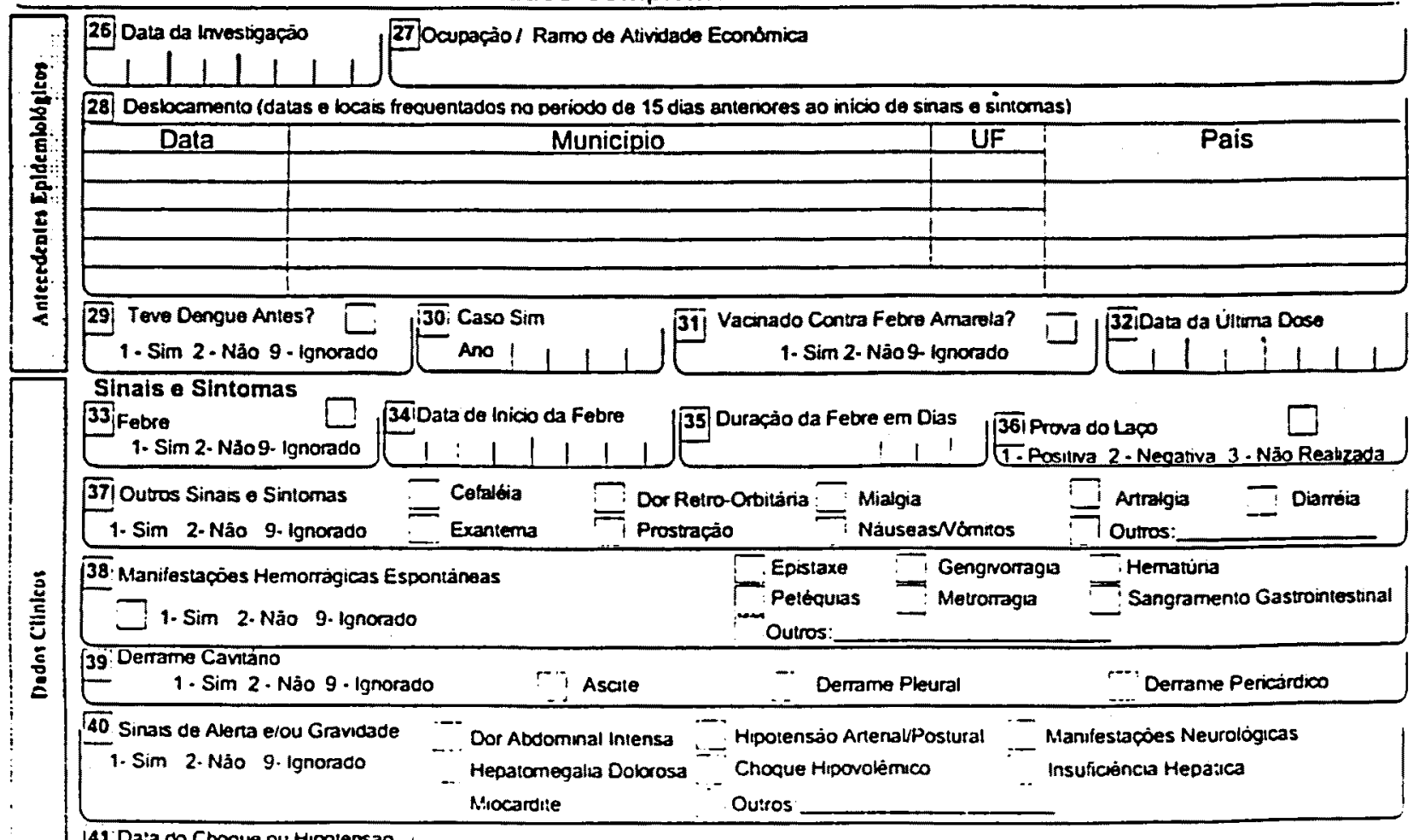




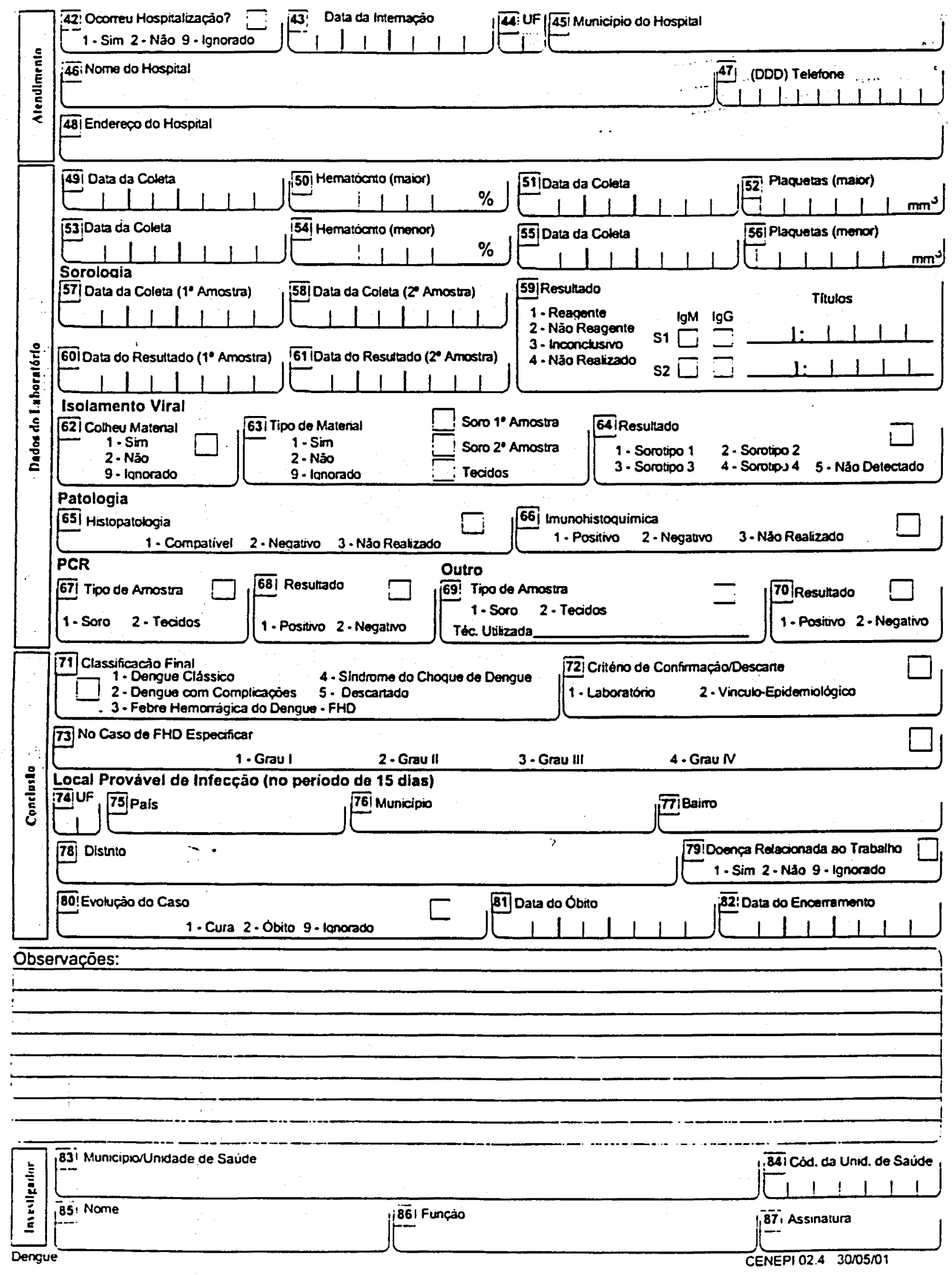

